\title{
20. PALYNOLOGY OF MIDDLE CRETACEOUS BLACK CLAY FACIES FROM DEEP SEA DRILLING PROJECT SITES 417 AND 418 OF THE WESTERN NORTH ATLANTIC
}

\author{
Peter Hochuli and Kerry Kelts, ${ }^{1}$ Geological Inst. ETH-Z, CH-8092 Zürich, Switzerland
}

\begin{abstract}
A palynological study of 23 samples of black and green claystones of middle Cretaceous age recovered from DSDP Sites 417 and 418 documents the position of a subtropical flora interference belt in a climatically differentiated North Atlantic realm.

A relatively large dinoflagellate/pollen ratio and lack of significant wood cuticle suggest moderately long-distance transportation of landderived components by surface currents. These components tend to decrease numerically upsection, but show a uniform composition. These sediments fit into the pollen-zones I, II, and III ranging from the early Aptian to early Cenomanian (Doyle and Robbins, 1977). Several new angiosperm forms are identified, including the oldest known occurrence of a monoporate form. Dinoflagellates, acritarchs, and microforaminifers dominate the palynomorph spectrum. Their occurrence is closely linked with complex lithologies interbedded on a decimeter scale. The palynomorphs are equally well preserved, but vary in abundance in the black and green claystones and are rare in nannofossil chalks, radiolarian sands, or red-brown clays to marls. The overall sedimentation rate appears to have been slow, but individual thin, carbonaceous black clay beds are commonly dominated by a single dinoflagellate species which may be evidence of high productivity following circulation events in a closed basin.
\end{abstract}

\section{INTRODUCTION}

In the controversy concerning the origin of the black clay facies in the middle Cretaceous Atlantic basin, the type of organic matter involved plays a central role. On several DSDP legs (e.g., Legs 11, 41, 47, and 48), Cretaceous black clay samples have been taken from sites close to the continental margin which were rich in terrestrially derived organic matter. Recent organic geochemical data have also tended to emphasize influxes of terrestrially derived organic matter (e.g., Tissot et al., 1974; and Deroo et al., 1978); earlier studies of the black clay had suggested oceanic sources (e.g., Lancelot et al., 1972; and Ryan and Cita, 1977). Thus, some authors (e.g., Montadert, Roberts, et al., 1976) question the necessity of basinwide stagnation to explain the typical black clay beds from the Atlantic midCretaceous, preferring instead a redistribution of landderived carbonaceous components by turbidity currents. The purpose of this paper is to consider these questions in the light of palynological evidence, while reporting the results of palynological investigations of material recovered during Legs 51 through 53 (Figure 1).

In the course of drilling on the southern tip of the Bermuda Rise at Sites 417 and 418 during Legs 51 through 53,

\footnotetext{
'Present address: Scripps Institution of Oceanography, Deep Sea Drilling Project, Mail Code: A-031, La Jolla, California 92093.
}

we recovered continuous cores from well-developed sections of Aptian to Cenomanian black clay facies sediments. These sites are uniquely suited for palynological examination for several reasons. Both sites are located on oceanic crust from the same magnetic anomaly, $M-0$, implying equal ages. They are only $8 \mathrm{~km}$ apart, permitting examination of lateral variability of possible correlative sequences. The basement age was determined as early Aptian (Gartner, this volume) or about 115 million years (van Hinte, 1976). From a reconstruction of the subsidence history of this location (e.g., Sclater et al., 1977), it follows that these sites were the locus of deposition at depths between 2000 and 3000 meters on a mid-ocean ridge during times of possible euxinic events and maximum preservation of organicmatter. The ridge environment provides an opportunity to examine dominantly pelagic sedimentation, thus avoiding the problem of turbidity currents resedimenting terrestrial carbonaceous matter. The sediments should represent an actual pelagic rain.

With respect to land flora, these sites, when plotted with other black clay sites on a reconstruction of the Aptian to Albian Sea (Figure 2) (Sclater et al., 1977), are distant from land sources. Several hundred kilometers to the south, a belt of shallow reefs was flourishing. The position of the tropical flora belts (after Brenner, 1976) (Figure 2) indicates that Sites 417 and 418 lie in a transition subtropical zone midway between Sites 367 and 105 . Because the Albian to Aptian period is also the time of the rise of angiosperms, new forms were expected. 


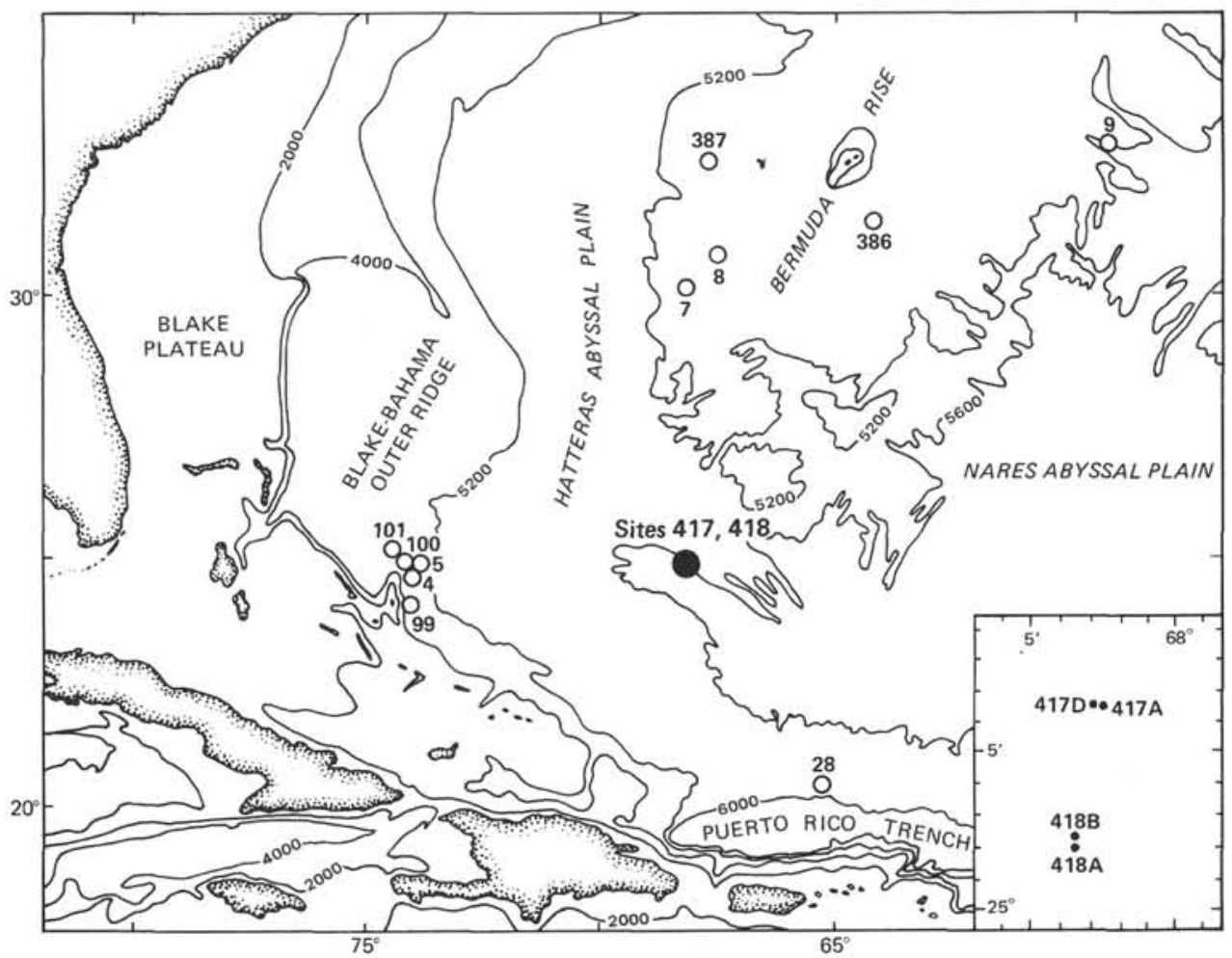

Figure 1. Index map of the locations of Sites 417 and 418 from Legs 51 through 53. Inset indicates the spatial relationships of the four holes drilled. All are on crust along the M0 magnetic anomaly with Sites 417 and 418 about $8 \mathrm{~km}$ apart.

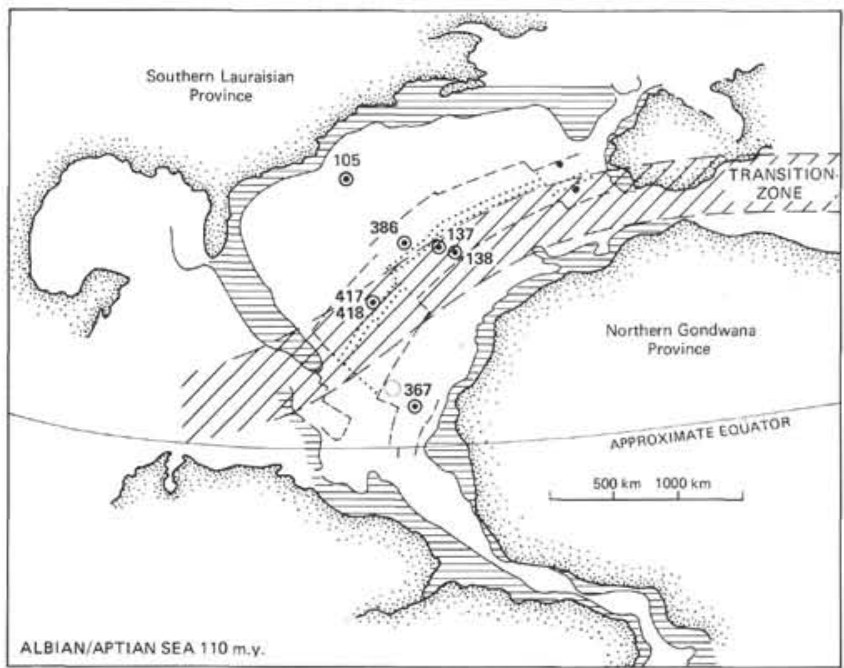

Figure 2. Reconstruction of North Atlantic paleogeography during Aptian to Albian times after Sclater et al., 1977. This shows the major physiographic features and approximate location of floral provinces (Brenner, 1976) in relation to the paleomagnetically determined equator (after van der Voo and French, 1974). Hatched areas may have been shallow during Middle Cretaceous.

In this study we have given particular consideration to the relationships between palynomorph stratigraphy and the diversified sediment types encountered on a decimeter-scale in these cores, so as to reduce the randomness of the paleontological data.

\section{LITHOLOGY}

The total sediment section on Hole 417D is 343 meters thick and for Holes $418 \mathrm{~A}$, and B only $8 \mathrm{~km}$ to the south, it is 320 meters thick. The black clay facies from early Aptian to middle Cenomanian is about 55 meters in Hole 417D, and 65 meters in Hole 418 of this facies lies directly above the igneous basement at both sites; basement recovery in the black clay interval was about 28 to 34 per cent. Using the van Hinte (1976) time scale, the thickness indicates an overall sedimentation rate of 2 to 3 meters per million years, which is typical of pelagic sedimentation. Chert layers, which form the contact with overlying barren, oxic zeolitic multicolored clays may indicate a significant hiatus in the Cenomanian. Another hiatus may occur in Hole 417D between the early Aptian and late Aptian to early Albian.

Carbonaceous clay beds form only a minor portion of the sediment column. The black clay facies is a combination of varied - in some cases, cyclic - lithologies that change rapidly on a centimeter scale. Some contacts are abrupt, others transitional. Intercalated "black clay" beds are black to gray, and may be either laminated or burrowed, waxy or crumbly and contain from 1 to 8.6 per cent carbon (Deroo, this volume). Waxy, fine-grained black clays show essentially the same mineral composition as surrounding green clays. The green clays also show black burrow fillings (Figure 3). Disseminated pyrite is common and some pyrite nodules occur in both types of clay. Abundance of palynomorphs however, is somewhat greater in the black than in green layers. Radiolarians are common in Sections 417D19-21 and 418B-29-34 (upper Aptian to upper Albian), and 


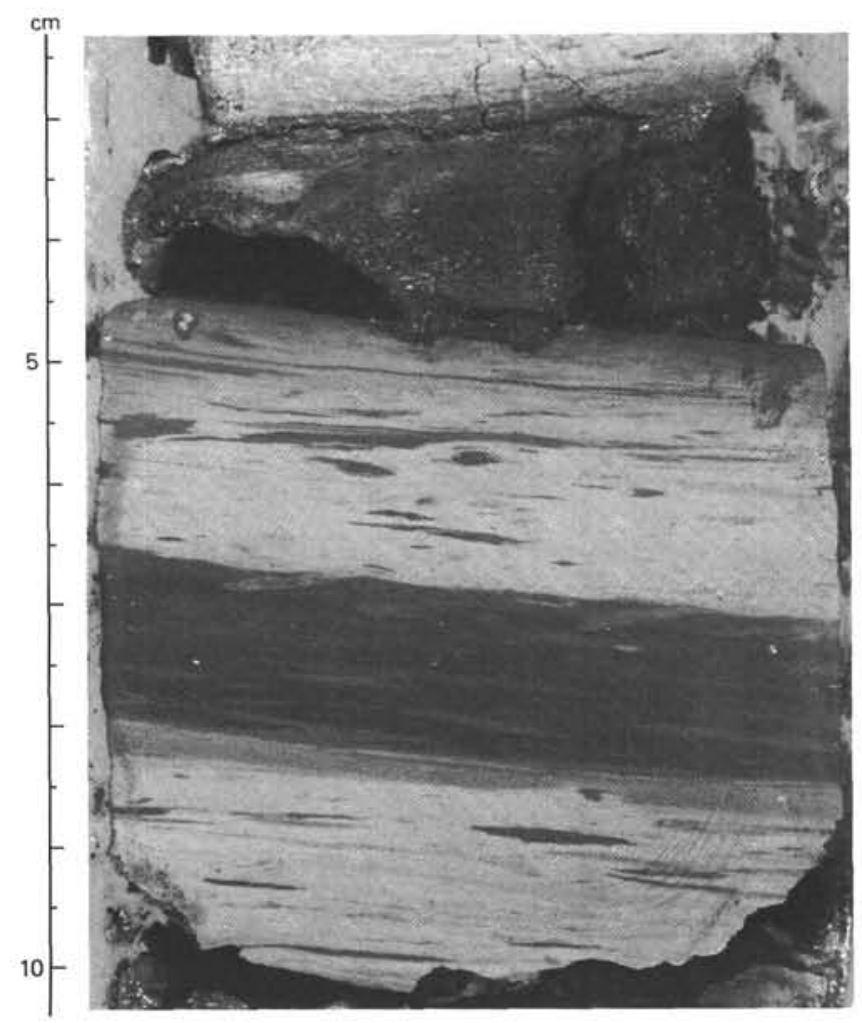

Figure 3. Typical black and green carbonaceous clay cycle.

sandy radiolarian beds may be pitch black, light green, or red. Intercalated nannofossil chalks occur in numerous sections as white, light green, olive-gray or gray beds; some are thinly laminated. Induration levels vary - a fact which may have affected the drilling recovery. Radiolarian sands may be cemented by silica-chalk and opal-CT, while some carbonaceous clay is crumbly and easily washed from the core barrel.

On a broad scale, Holes 417D and 418B are easily correlated. Zones with a high density of the black clay layers are encountered in upper Albian to the middle Cenomanian Cores 417D-17 through 19 and 418A-10 and Section 418B-29-31 as well as the basal part of the column (lower Aptian) in Sections 417D-21-3 and 418B-34-1. Between these zones, Sections 417D-20-1 to 21-1 and Cores 418B32 and 418B-33 (upper Aptian to middle Albian) record a period of oxic conditions in which the same lithological types are dominantly reddish brown to pale-green radiolarian sands, nannofossil chalks, marls, and clays. Palynomorphs are rare in these more oxidized sediments.

Most palynomorph samples were selected from reduced sediments, particularly black layers. For comparison, samples of the green clay and dark-olive nannofossil chalk were also examined. Good preservation was not limited to the black beds. In gray beds where some calcite and a few nannofossils persist, the condition of the palynomorphs was excellent.

Table 1 lists the samples and their corresponding lithologic character. In some crumbly black clay beds, palynomorphs, and a few scattered wood cuticles dominate the bulk smear slides. In other carbonaceous layers, much of the organic matter visible in bulk smear slides collects in amorphous masses. In some of the pitch black radiolarian sand layers, the density of pollen and dinoflagellates is very low. The black coloration of these sands may result from impregnation by immature hydrocarbons. Under only 250 meters of overburden, sediments would probably not be warmed above $50^{\circ} \mathrm{C}$ and diagenetic changes are minimal, as indicated by isotope studies (McKenzie and Kelts, this volume). Single samples probably represent time spans on the order of 5000 to 20,000 years, which is within the realm of variability for oceanic currents and upwelling but not broad tectonic movements.

\section{METHODS}

All of the samples have been prepared by the standard palynological procedure using concentrated $\mathrm{HCl}$ and $\mathrm{HF}$. The samples were dissolved with $\mathrm{HF}$ at room temperature for about 30 hours, without use of an oxidizer. The very finest grained organic material was removed using a sieve with a mesh of 14 microns. The residues were then mounted in glycerine jelly for optical counting. The taxonomic descriptions of the species are given immediately preceding the plate captions.

\section{STRATIGRAPHY AND CORRELATION}

In the palynological spectrum observed in the middle Cretaceous samples from Legs 51 through 53 we can separate the flora elements into three groups. These flora types match well with the zonal scheme established by Brenner (1963) and Doyle (1969). The floral elements from the top of the sediment sequence also match well with the zonal scheme for the South American middle Cretaceous flora (Herngreen, 1975). Primitive angiosperm pollen (Clavatipollenites, $R e$ timonocolpites, and Tricolpites) form the most important stratigraphic marker assemblages along with the gymnosperm groups (Classopollis and Elaterosporites). Dinoflagellate cysts and acritarchs may occur as sudden pulses in which a limited number of species dominate the spectrum. The dinoflagellate peaks have been used to establish a correlation between Sites 417D and 418B (see Figure 4 and Tables 2 and 3). The dinoflagellate-cyst assemblages do not contain the index forms that Habib (1977) used to subdivide the Aptian to Cenomanian. The relative abundance of dinoflagellate-cyst assemblages serves as a guide to monitor land-derived input.

\section{Leg 51B, Hole 417D}

\section{Sections 21-3 and 21-4}

Four samples were examined from the sediments recovered from the last 2 meters above the basalt contact in Hole 417D. Two contained a well-preserved microflora, in which dinoflagellate cysts are the dominant palynomorphs. The spectrum is dominated by two, respectively three, species: Druggidinium deflandrei and Dictyopysidia reticulata in both samples, while in addition Prolixosphaeridium granulosum is prominent in the younger specimen (Sample 417D-21-3, 55-56 cm).

The most common pollen form in this zone is the gymnosperm, Classopollis noeli. Angiosperm pollen are very rare in the lowest part of the section. The only representative found in these sediments is Clavatipollenites; other types such as monocolpates and tricolpates are absent. The assemblage therefore best fits into the Zone I established by Brenner 
TABLE 1

Listing of Samples From Legs 51 Through 53, Sites 417 and $418^{a}$

\begin{tabular}{|c|c|c|c|}
\hline & $\begin{array}{c}\text { Sample } \\
\text { (Interval in } \mathrm{cm} \text { ) }\end{array}$ & Description & Carbonate \\
\hline \multirow[t]{12}{*}{ Leg 51, Hole 417D } & $17-1,52-54$ & Light gray, thinly laminated, hard mudstone & traces \\
\hline & $17-1,94-95$ & Waxy green clay & minor \\
\hline & $17-3,65-66$ & Olive-gray chalk & $60 \%$ \\
\hline & $17-3,127-128$ & Black clay, rich in organic matter & trace \\
\hline & $17, \mathrm{CC}$ & Black crumbly clay with pyrite & none \\
\hline & $18-1,3-4$ & Black crumbly clay & trace \\
\hline & $18-2,16-19$ & Pale-green clay, pyritic radiolarians & trace \\
\hline & $19-2,6-8$ & Dark-gray mudstone & trace \\
\hline & $19-2,11-14$ & Black clay with thin wispy white laminations & none \\
\hline & $21-1,108-110$ & Hard, grainy black and burrowed green clay & none \\
\hline & $21-3,55-56$ & Black crumbly clay, pyritic radiolarians & trace \\
\hline & $21-4,22-24$ & Light-gray laminated chalk & $80 \%$ \\
\hline \multirow[t]{2}{*}{ Leg 52, Hole 418A } & $10-1,95-97$ & Gray and black laminated mudstone & none \\
\hline & $10, \mathrm{CC}$ & Black mudstone & none \\
\hline \multirow[t]{9}{*}{ Leg 53, Hole 418B } & $28-2,53-55$ & Dark-olive gray mudstone with nannofossils & $10 \%$ \\
\hline & $28-3,75-77$ & Dark grayish brown & minor \\
\hline & $29-2,91-92$ & Black cycle, with nannofossils & $20 \%$ \\
\hline & $31-2,4-6$ & Black clay, sub-millimeter laminations & none \\
\hline & $31-2,11-13$ & Black, crumbly, coarse mudstone & trace \\
\hline & $34-1,6-7$ & Transitional greenish gray clay & none \\
\hline & $34-1,10-13$ & Coarse, greenish black clay & none \\
\hline & $34-1,15-16$ & Black, carbonaceous, radiolarian molds, nannofossils & $30 \%$ \\
\hline & $34-1,30-31$ & Black, sandy mudstone & none \\
\hline
\end{tabular}

${ }^{\mathrm{a}}$ Carbonate estimates from X-ray data.

(1963), or into the Clavatipollenites-Zone of Habib (1977). The range of this zone encompasses the entire Barremian and Aptian, and possibly the lowest Albian. There are also a few gymnosperm index forms which would indicate an age not younger than late Aptian. The one exception is Classopollis brasiliensis; this species was described by Herngreen (1975) as first appearing in the middle Albian. It is, however, present in all of the samples from Holes 417D and 418B.

\section{Cores 417D-21 to 417D-19}

The flora from these cores is characterized by the appearance of several new angiosperms. Clavatipollenites is still present. The pollen spectrum contains additional monocolpate forms including Retimonocolpites dividuus, $R$, reticulatus, and $R$. peroreticulatus. Furthermore, the first tricolpate forms (Tricolpites crassimurus and $T$. parvulus) also appear in these samples. Zone II (Brenner, 1963; and Doyle and Robbins, 1977) matches best with this microflora assemblage. Any division into subzones is merely speculative, and is hindered by the lack of good index forms. The flora of Zone II begins in early to middle Albian and ranges up to late Albian. Here the gymnosperm pollen, Welwitschiapollenites, appears. We are yet uncertain whether a stratigraphic significance can be attached to the appearance of this genus. Several other forms provide clues to the age designation, including scattered spores such as Cicatricosisporites mohrioides, Aequitriradites sp., and Klukiasporites areolatus. The occurrence of these species is confined to the middle Albian.

The dinoflagellate flora of this section is characterized by the initial appearance of Ginginodinium spinulosum and the extreme dominance of this species in the samples from Core 417D-19.

Lithosphaeridium conispinum and Cribroperidinium $\mathrm{sp} .1$ also occur for the first time. According to available studies, Ginginodinium spinulosum is limited to Albian and Cenomanian, while Lithosphaeridium conispinum can be traced back to the late Albian (Harker and Sarjeant, 1975).

\section{Cores 417D-18 and 417D-17}

The appearance of other tricolpate angiosperm pollen characterize the sediment section in Cores 18 and 17. Common forms include Tricolpites barrandei and T. nemejci. The appearance of both these species is characteristic of Zone III (Doyle and Robbins, 1977). Other index forms are also present; although scarce, we could observe Striatopollenites dubius and Tricolpopollenites macroreticulatus. The former begins in Albian (Jardiné and Magloire, 1962; Morgan, in press), while the second ranges from late Albian to Cenomanian. Further evidence for the assignment of this section to Zone III (Doyle and Robbins, 1977) includes the diverse variety of tricolpate angiosperm pollen and the complete absence of triporate types (Normapolles). This zone spans the interval from late Albian possibly through to early Cenomanian. The zonation of Habib (1977) differs slightly from this scheme. Zones II and III are combined into the Retitricolpites georgensis-Zone. The subzones IIA and IIB of Brenner (1976) correspond approximately to the Tricolpites minutus-Subzone of Habib (1977). The subzones IIC and Zone III are equivalent to the Psilatricolporites-Subzone, whereas Zone IV is called the Complexiopollis-Zone based on the occurrence of Complexiopollis. 


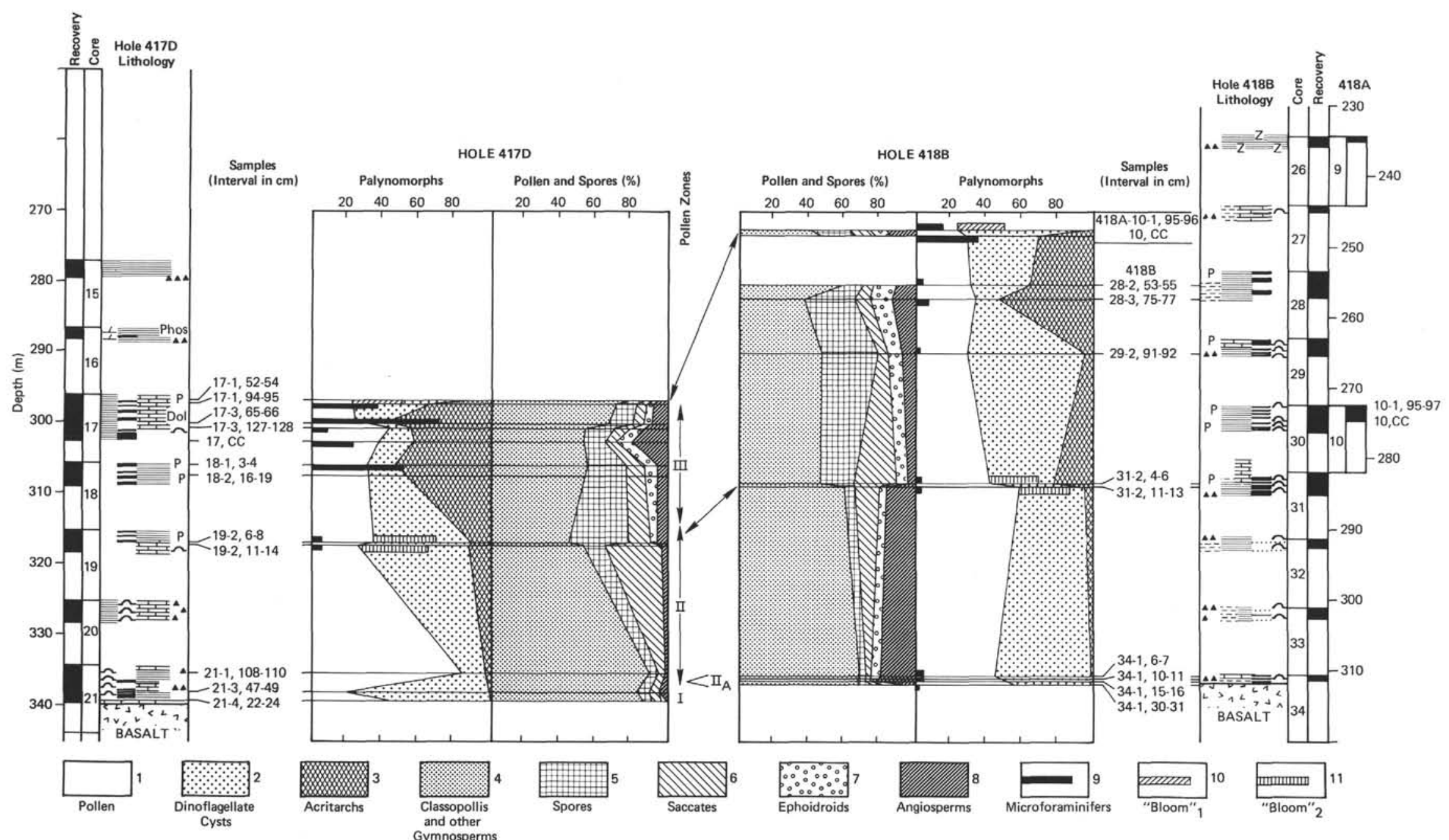

Figure 4. Compilation of palynomorph frequency and the stratigraphic position of palynology samples from Sites 417 and 418 . Lithologic symbols are as defined in the site chapters. Dinoflagellate zonation I, II, and III (Doyle, 1969) is given in the center column with tentative correlation markers. Samples from the WashCore 418A-10 (right column) have been repositioned by the flora to fall above Hole 418B. Relative frequencies are given for: 1) pollen, 2) dinoflagellates, 3) acritarchs, 4) Classopollis and other gymnosperms, 5) spores, 6) saccate pollen, 7) ephedroide grains, 8) angiosperms, 9) microforaminifers, 10) dinoflagellate bloom Canningia rotunda, and 11) dinoflagellate bloom Ginginodinium spinulosum. In the lithology column, black carbonaceous clay beds are marked by bars; $Z=$ zeolite, $P=$ pyrite. 
TABLE 2

Palynomorph Species Ranges From Hole 417D

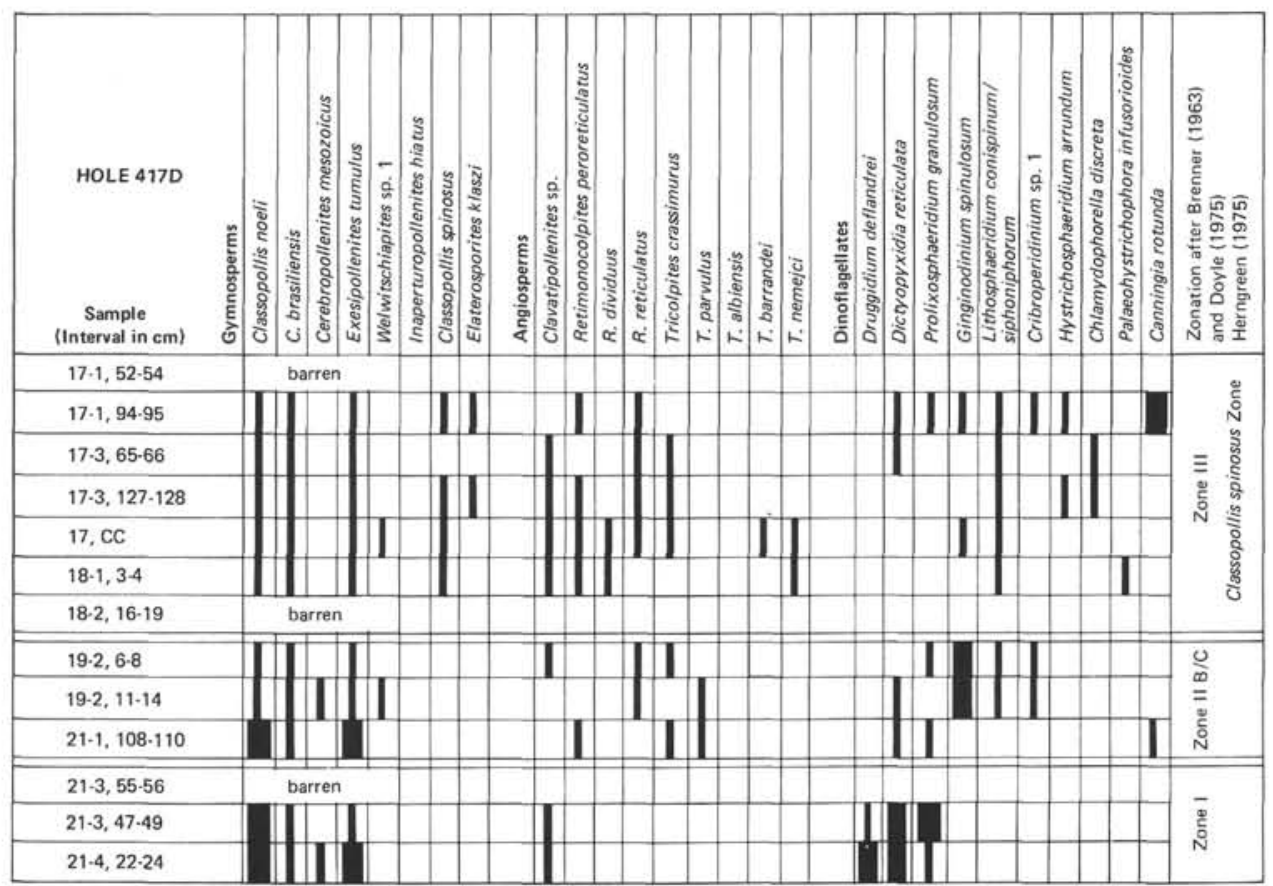

TABLE 3

Palynomorph Species Ranges From Holes 418A and 418B

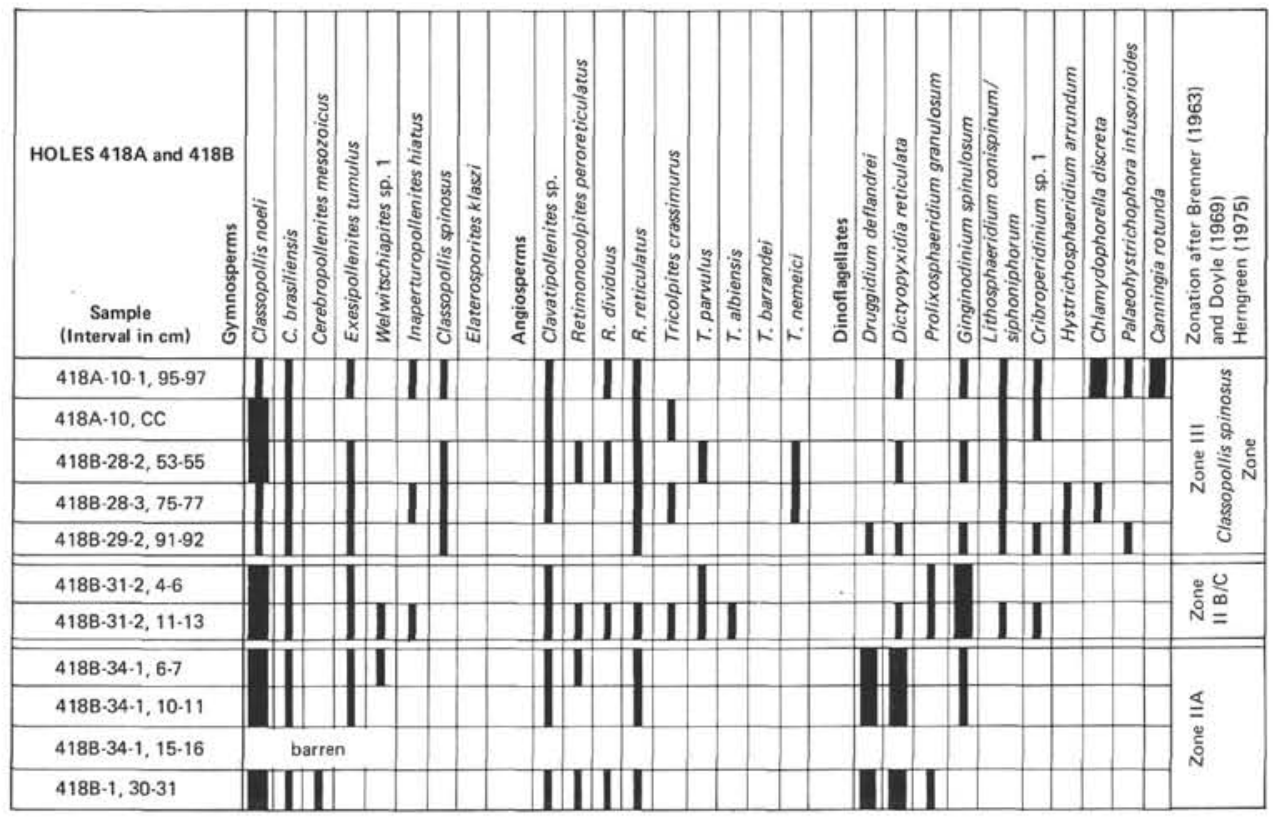

The stratigraphic age assignments are also supported by the regular occurrence of Classopollis spinosus and the rare occurrence of Elaterosporites klaszi. In Brazilian sections, C. spinosus is limited to the lower part of the Elateroplicites-Zone and is the index fossil for the Classopollis spinosus Subzone (Herngreen, 1975). The Classopollis spinosus Subzone probably is equivalent to late Albian. The Elateroplicites-Zone comprises the late Albian and early Cenomanian. Elaterosporites klaszi has a broader range than
C. spinosus from late Albian to late Cenomanian. Both these species are typical floral elements of the tropical regions. The samples from Sites 417 and 418 therefore represent a bridge, allowing a direct correlation between a tropical floral belt and floral zones from higher latitudes contemporaneous with the Albian Sea.

The dinoflagellate assemblage from Cores 417D-18 and 17 is characterized by the first occurrence of Hystrichosphaeridium arrundum, Chlamydophorella discreta, and 
Canningia rotunda. $H$. arrundum first appears in the Albian whilst as yet $\mathrm{Ch}$. discreta is only known from Cenomanian sediments (Harker and Sarjeant, 1975). Lithosphaeridium siphoniphorum and Canningia rotunda become particularly common in the upper part of the section.

\section{Core 34}

Recovery was poor in the lowest core of Hole 418B. This would explain why the last meter of light-gray lower Aptian nannofossil chalks found in Section 417D-21-4 are absent here. The flora from the lowest samples from Site 418 (Section 34-1) is confidently assigned to Zone II based on the relatively common occurrences of monocolpate angiosperm pollen as well as sporadic occurrences of tricolpate types. A more refined positioning into Subzone IIA is indicated by the relatively common occurrence of Clavatipollenites compared with scarcer tricolpate forms, namely Tricolpites crassimurus, $T$. parvulus, and T. albiensis.

The dinoflagellate assemblage is dominated by Druggidium deflandrei and Dictyopyxidia reticulata which is very similar to the spectrum at the base of Hole 417D (Sections 21-4 and 3). The appearance of Ginginodinium spinulosum, on the other hand, is more suggestive of a slightly younger age placement within the early Albian. Welwitschiapollenites also occurs in these samples. Another indication of Albian age is the presence of Klukisporites areolatus.

\section{Core 31}

Core 418B-31 samples are dominated by the single species, Ginginodinium spinulosum. The unique character of this "bloom" can be directly correlated with Section 19-2 from the Hole 417D sequence. Lithosphaeridium siphoniphorum and Cribroperidinium sp. 1 also appear for the first time in the assemblage. In comparison with Core 418B-34, the angiosperm pollen spectrum shows a greater abundance of the tricolpate types: Tricolpites crassimurus, $T$. parvulus, and $T$. albiensis. It follows that this section belongs in the upper part of Zone II. The presence of the gymnosperm pollen, Inaperturopollenites hiatus, also has stratigraphic implications. According to Singh (1971), these forms range in the middle Albian.

\section{Cores 418B-29 and 28 and 418A-10}

Late Albian or early Cenomanian (Zone II, Doyle and Robbins, 1977, or Classopollis spinosus-Zone, Herngreen, 1975) ages are indicated by the flora from the uppermost part of the sequence examined from Cores 418B-29 and 28 and 418A-10. These samples correspond to the youngest occurrences of black clay beds. Evidence includes the angiosperm assemblage as well as the occurrence of Classopollis spinosus. The dinoflagellate assemblage is characterized by Hystrichosphaeridium arrundum, Chlamydophorella discreta, Palaeohystrichophora infusorioides, and Canningia rotunda.

The obvious similarity between these samples and Core 17 from Hole 417D can be used to solve a drilling problem. Core 418 A-10 was taken at 272 to 282 meters below the sediment surface. The black clay lithology of the 1.5 meters of recovered sediment is most similar to sediments at 250 meters sub-bottom from Core 28 in Hole 418B, drilled only 40 meters away. The excellent floral match indicates that during the 27 meter wash-down for Core 418A-9, sediments from the upper black clay sequence were jammed into the core harrel while sediments from the nominally cored interval were excluded (see Figure 4).

\section{ASPECTS OF ANGIOSPERM EVOLUTION}

Samples from Legs 51 through 53 document a time span during which angiosperms underwent rapid development. The relatively detailed palynological stratigraphy in the Aptian to Cenomanian section reflects the rapid evolution of this group. Samples from pollen Zone I from Site 417D, Sections 21-3 and 4 record an initial phase of angiosperm development. Only the most primitive monocolpate types from the genus Clavatipollenites occur. In particular, this includes the forms Clavatipollenites hughesi and C. tenellis. From a taxonomic point of view, this form-group appears to be related to modern forms of the Magnoliales. None of the other monocolpate forms which might be expected in this pollen Zone I (e.g., Retimonocolpites and Stellatopollis) was found in these samples. Monocolpate pollen forms dominate a considerable time span in the phases of early angiosperm evolution. They range with certainty from Barremian into the early Albian, encompassing at least 10 million years.

The succeeding evolutionary phase is manifested in the lowest samples from the section in Hole 418B, where forms are much more diversified. Clavatipollenites continues while, in addition, several forms of the genus Retimonocolpites occur along with other monocolpate types. The first few tricolpate forms appear. This, more differentiated spectrum of pollen morphologies corresponds stratigraphically to the lower parts of pollen Zone II, probably equivalent to Subzone IIA or early Albian.

Morphologically, the genus Retimonocolpites represents a special evolutionary trend. It is commonly compared with the Liliacidite-form group although it differs by having a longer colpus, which generally encircles more than $180^{\circ}$ of the pollen grain. Retimonocolpites also differ by the type of connection between the endexine and the reticulum. In $R e$ timonocolpites, the reticulum is moderately thick and only loosely connected with the endexine. For this reason the reticulum is commonly found separated from the inner layer (see Plate 5, Figures 32 through 34 and Plate 6, Figures 7 and 8). We interpret this genus as an isolated angiosperm group which flourished briefly in Aptian and Albian times before fading in the Cenomanian. There should be a clear taxonomic separation between this form and the relatives of the Liliaceae $\mathrm{s}$. which show fossil lineage through forms such as Liliacidites and Arecipites.

Two other noteworthy pollen types with distinct angiosperm affinity occur in this interval, although they are not numerous. The first is a monocolpate form (Monocolpate sp. A, Plate 5, Figures 25 through 27) with foveolate sculpture. The sculpturing and form of the colpus indicate a relationship with pollen morphology of recent monocotyledons, in particular Restionaceae and Centrolepideceae. The second form ("Trichotomosulcites" sp. 2, Plate 5, Figures 35 through 37 ) is trichotomosulcate and displays irregularly intergrown structural elements. According to the evolutionary concept of Muller (1970), trichotomonocolpate types represent a transitional stage between monocolpate 
and tricolpate forms. Modern analogies include similar pollen grains from monocotyledons, for example palm trees.

The next phase is documented by pollen from the intervals $417 \mathrm{D}-21-1,108$ to $110 \mathrm{~cm}, 19-2,11$ to $14 \mathrm{~cm}, 19-2,6$ to $8 \mathrm{~cm}$, and in the intervals $418 \mathrm{~B}-31-2,11$ to $13 \mathrm{~cm}$ and $31-2,4$ to $6 \mathrm{~cm}$. Tricolpate pollen grains become more prominent than monocolpate types. Increased differentiation is manifested by differences in surface structures and sculpturing. The spectrum corresponds to angiosperm from the upper part of pollen Zone II (B and C zones of Doyle and Robbins, 1977). Both of these subzones approximate the middle and the lower part of the late Albian. Monocolpate forms show greater diversification. Clavatipollenites is still common, while Retimonocolpites groups attain their maximum development. Along with the forms given in Table $1, R$. textus and $R$. echinatus appear. Single pollen grains from other monocolpate forms were observed as well. We classified two types with fine reticulum and thick columellate structures with the genus Arecipites (Arecipites sp. 1 and Arecipites sp. 2, see Plate 5, Figures 3 through 7). Another form designated as Magnolipollis sp. 1 shows morphological similarities with recent magnolia pollen. A fourth type was compared with Monocolpopollenites tranquillis verrucatus which is comparable with recent palm varieties. Similar forms such as the reticulate- and columellate-structured "Trichotomosulcites' sp. (Plate 5, Figures 29 through 31) also occur in recent palms. The botanical affinity of one syncolpate form with foveolate sculpture (monocolpate sp. B, Plate 5, Figures 23 and 24) remains unclear.

A single grain was found in the same interval which has an irregular, restricted pore and scorbiculate sculpture (Milfordia sp. 1, Plate 5, Figures 21 and 22). A morphological comparison suggests this pollen type is related to the recent Restionaceae. This is the oldest reported instance of a monoporate form. Previously, its first appearance was known only from upper parts of the Late Cretaceous (Jardiné and Magloire, 1965).

The next phase includes pollen associations of the pollen Zone III. It is documented by Samples 418B-29-2, 91-92 $\mathrm{cm}, 28-3,75-77 \mathrm{~cm}$, and 28-3, 53-55 cm; 418A-10, CC, 10-1, 95-97 cm, and 417D-18-1, 3-4 cm, as well as all samples from Core 417D-17. They are characterized by the increasing prominence of the angiosperm types and in particular by greater differentiation within the tricolporate types. In several species there are indications of the beginning of pore formation. In the uppermost interval of this zone we expected to find tricolporate forms with highly differentiated ornate sculpturing. Such types are, however, absent in our samples. This is an indication that our profile extends upward to include only the lower part of the pollen Zone III, or early Cenomanian.

The rich and well-preserved flora in the samples from Sites 417 and 418 underlines the diversity already attained by angiosperm populations in the middle Cretaceous. Monocolpate, syncolpate and trichotomosulcate types, which have been considered primitive forms, show various (and some advanced) degrees of differentiation. Many show morphological similarities that can be closely linked with the recent Monocotyledons.

\section{PALEOBIOGEOGRAPHY AND CLIMATE}

The palynomorph spectrum of the land-derived components in the samples examined from Legs 51 through 53 do not show major variations that could be related to a significant climatic trend. It is thus possible to treat the results as a whole in the following discussion. The placement of the Aptian to Cenomanian flora from Sites 417 and 418 into a climatic framework was attempted by a relative comparison with those spectra available from the European and North American Cretaceous on the one hand and profiles from equatorial provinces on the other. An approximate reconstruction (Sclater et al., 1977) has been presented in Figure 2. Note that a paleolatitude determined from underlying basalts at Site $417 \mathrm{~A}$ was $11.6^{\circ} \mathrm{N}$ (Bleil and Smith, this volume). This seems rather low because the middle Cretaceous (Aptian to Cenomanian) is considered a time of general worldwide climatic amelioration and this latitude would imply a more tropical flora regime. The pollen spectrum in a midbasin marine environment is, of course, a secondary phenomenon. It is dependent on factors other than primary production including direction of currents and wind transport, river drainage, arid zones, and continental mass distribution. If the paleolatitude from magnetics is correct, it is somewhat surprising to find subtropical and tropical elements combined in the flora spectrum of Sites 417 and 418, indicating a transitional position between the northerly, subtropical Southern Laurasian Province and the more southerly and tropical Northern Gondwana Province. These results have been combined with information from the Lower Cretaceous of the Southern Alps (Hochuli, in preparation) to define a floral transition zone (Figure 2).

The sporomorphs which dominate the samples from the western North Atlantic are almost exclusively Classopollis. There is a conspicuous lack of saccate pollen as compared with sections from Northern Europe and North America. Only rare examples, such as Alisporites, Cedripites, Parvisaccites, and Podocarpidites occur. One exception is Vitreisporites pallidus, which is common in several samples. In contrast, saccate pollen comprise the major group in the corresponding stratigraphic intervals for the boreal realm. These types are almost entirely excluded from equatorial regions (Herngreen, 1975; Brenner, 1976). Another example is the relatively common occurrence of ephedroid pollen-grains in samples from Sites 417 and 418 . Here these forms are almost as common as the saccate pollen, while extremely rare in European spectra. Thus, floras from Site 417 and 418 resemble closely floras from the equatorial South American/African Province. This has been referred to as the AAS-Province by Herngreen (1974) or the Northern Gondwana Province by Brenner (1976).

There is a problem with this comparison. The main characteristic of these tropical-province floras is the occurrence of forms from the Elaterosporites group. No modern plant group is known which can be related to these elaterbearing pollen forms. Yet, they show a tremendous development in equatorial regions ranging from the latter part of the Early Cretaceous to the early part of the Late Cretaceous. On the other hand, they have a very limited distribution. In samples from Hole 417D, only a few rare examples 
of Elaterosporites klaszi could be identified. By comparison with the distribution charts of Herngreen, 1975 (Fig. 7), the rare appearance of $E$. klaszi at Site 417 constitutes the northernmost reported occurrence of this species to date.

In summary, the pollen spectrum of Sites 417 and 418 lies in a transitional flora belt. The occurrence of Elaterosporites and the abundance of ephedroid pollen grains shows distinct affinities with an equatorial flora from the Northern Gondwana province. The presence of saccate pollen points to a relationship with boreal belts of the Southern Laurasia Province. Both the saccate pollen and the elaterbearing forms are scarce, which indicates that these samples derive from a region peripheral to both these major flora zones. There appears to have been a significant regional floral gradient. Bisaccate forms are well-adapted to current transport, and further investigation of other Albian to Aptian deep-sea and land sites may define paleocurrent patterns.

Any climatic interpretation of Cretaceous flora is made with great reservation. This applies particularly to the equatorial regions. The botanical affinities of the main floral elements are completely unknown. We can assume that the characteristic floral elements of the boreal regions, Pinaceae and Podocarpaceae types, derive from a relatively humid, temperate climate and would tolerate a broad temperature range. Fern spores are also common along with the saccate pollen, in boreal regions. Some of these, for example Schizaeceae, show affinities to present-day families that are exclusively tropical or subtropical. For this reason Brenner (1976) designated this association as the Southern Laurasia Province. The corresponding climate is considered warm temperate to subtropical. Brenner (1976) used several criteria to conclude that the climate in the North Gondwana Province of the Middle Cretaceous, while tropical, had some strong semi-arid overprints. Pinaceae and Podocarpaceen pollen are scarce, as are the Pteridophyte spores which resemble the Schizaeceen. Pollen grains from forms related to Ephedra along with Welwitschia and Classopollis suggest tropical, but semi-arid conditions.

\section{PALEOENVIRONMENT}

\section{Terrestrial Influence}

The Aptian to Albian central North Atlantic Sea was about $1500 \mathrm{~km}$ wide (Sclater et al., 1977), although land may have been present about $500 \mathrm{~km}$ to the south of Site 417 (see Figure 2). Land-derived organic components form a minor fraction of the flora examined in this study. Some fragments of wood cuticles and tissues occur in the prepared slides, but none of the particles exceeds 120 microns. As this is near the average size of pollen and spores, it follows that normal surface currents and winds were probably responsible for the distribution of terrestrial material fragments. The spectrum and size ranges are some evidence for a relatively long distance from Site 417 to the nearest major landmasses. Further supporting evidence is the lack of thick-walled spores. In flysch-like sediments and marine deposits with a heavy terrestrial overprint, such forms are particularly common along with coarse wood and tissue fragments. Turbidity-current distribution of land-derived components, particularly at the ridge Sites 417 and 418, seems unlikely. Very little, however, is known about the amount of land-derived organic matter or the pollen/ dinoflagellate ratios in the present-day Mid-Atlantic Ridge sediments (Farrington, personal communication). A qualitative evaluation of the palynomorphs suggests that organic particles of terrestrial origin may have been fractionated by relatively long-distance transport by surface currents.

In general, the percentage of pollen and spores in the palynological profiles tends to decrease in upward direction in the sediment column, indicating decreasing terrestrial influences. Possibly this represents a faint echo of late Albian transgressions onto the continents. A maximum in the quantity of land-derived components is observed at the base of Zone II (late Aptian to early Albian). The peak content of up to 8 to 10 per cent $C_{\text {org }}$ in the top of the section does not appear to correspond with the maximum indication of land-derived organic matter, but rather to dinoflagellate species "blooms." Along with a decrease in pollen and spores the upward onset and increase of microforaminifers document pelagic, open marine conditions. The delicate chitinous remnants of microforaminifers are rarely found in sediments along the continental margins. In contrast, dinoflagellates as yet give little indication of coastal distances. These microfossils may be abundant in nearshore sediments. Dinoflagellates are the dominant representative of marine phytoplankton in the lower parts of the sediment column from Legs 51 through 53. Very little is known about the systematic relationship or ecology of the other plankton forms recorded, such as Tytthodiscus, Monogemmites, and Pleurozonaria. It is noteworthy that they first appear along with the microforaminifers at the base of the pollen Zone II. In some samples they form a major portion of the phytoplankton assemblage. In the younger part of the section, these forms diminish in importance. The palynomorphs in the sediment column from late Aptian to early Cenomanian at both Sites 417 and 418 are clearly dominated by an open marine phytoplankton flora. A decrease in the pollen/ dinoflagellate ratio and corresponding increase in microforaminifers from late Aptian to early Cenomanian are interpreted as signs of further decline of terrestrial influences. Several mechanisms could lead to this situation including 1) a shift in the predominant oceanic current patterns, 2) parallel development to the inward migration of source areas due to mid-Cretaceous transgression and regression factors, 3) reductions in the outpourings of organic matter by the large delta complexes around the Aptian to Albian sea, 4) phytoplankton evolutionary trends, and 5) changes in the preservation of organic matter due to fluctuations in an anoxic boundary layer. More anoxic conditions would increase preservation of marine-derived organic matter with respect to more robust, refractory land-derived organic matter.

\section{"Blooms"}

One of the most conspicuous and puzzling observations is the rapid fluctuations and dominance of individual species in the phytoplankton spectrum. In the lower part of the section we see a dominance of Druggidium deflandrei and Dictyopyxidia reticulata (Sections 417D-21-4 and 21-3; and Section 418B-34-1). Subsequently, this phase wanes and is replaced by another low-diversity, limited-individual as- 
semblage. There follows a flora with predominance of Ginginodinium spinulosum. In the Hole $418 \mathrm{~B}$ section, this bloom follows directly the Druggidium-Dictyopyxidiella maximum. The maximum development of the Ginginodinium also corresponds to a marked increase in the number of cysts from Tytthodiscus, Monogemmites, and Pleurozonaria, as well as the expansion of microforaminifers. The Ginginodinium "bloom" preserved in Hole 418B, Section $31-2$, is followed by the first clearly polyspecific, rich dinoflagellate flora in Sample 418B-29-2, 91-93 cm. Shortly thereafter, in the next specimen, Sample 418B-28$3,75-77 \mathrm{~cm}$, we find the same assemblage considerably diminished, overwhelmed by a quantitative dominance of Tytthodiscus and Monogemmites. The next specimen, Sample 28-2, 53-55 cm, again shows a well-developed dinoflagellate spectrum. Here again a single species, Cleistosphaeridium huguonoti, plays the major role.

Samples from Core 418A-10 also contain a rich dinoflagellate spectrum, but here the most common species is Chlamydophorella discreta and, in addition, Canningia rotunda in the youngest specimen (Sample 418A-10-1, 95-97 cm).

The Ginginodinium maximum in Hole 417D is followed by a high-diversity dinoflagellate population. The number of individuals is low, however. This situation prevails in Samples 417D-18-1, 3-4 cm, 17, CC, 17-3, 127-128 cm, and 17-3, 65-66 cm. The cysts, Tytthodiscus and Monogemmites, dominate the flora. Dinoflagellates once again regain dominance towards the top of the sediment section, particularly by an increase in Canningia rotunda. The conspicuous abundance of this species suggests a direct correlation with specimens from Hole 418A (Sample 10-1, 95-97 $\mathrm{cm})$.

In summary, we note that the phytoplankton spectrum in the stratigraphic interval from early Aptian to middle Cenomanian in Sites 417 and 418 shows signs of rapid change in both quantitative and qualitative composition. Some variations could be attributed to preservation effects, but the conspicuous dominance of individual species, their rapid expansion, and short-time spans all suggest a phasal or bloom-like development of the planktonic flora. The paleoenvironment and depositional regime control the composition of the phytoplankton spectrum. It follows that the mechanisms of distribution, reproduction, and cyst formation are all governed by complex variables in the surface waters of the ocean at that time. We attribute the rapid, and fundamental fluctuations in assemblage character to primary, short-term changes in the paleoceanography. Near continents, such fluctuations could be the result of changes in upwelling patterns and in the input of land-derived organic matter. We have seen that the terrestrial spectrum, except for a quantitative decrease in upward direction, has a fairly uniform composition and texture indicating a more or less homogenized input. This would be expected if a site some distance from coastal areas was the locus of a pelagic rain that included land-derived components transported by surface currents.

It is possible that the rapid changes are a result of extreme variations in the nutrient budget. We recall that the samples examined for palynomorphs are about 1 to $3 \mathrm{~cm}^{3}$ and represent a likely interval on the order of 10,000 to 20,000 years.
This is the time scale on which climate-induced changes in oceanic circulation, such as the overturn of an euxinic basin, could be expected.

The ecology of ancient dinoflagellate forms is poorly known. From the study of recent lakes we know, however, that dinoflagellates (e.g., Peridinium) can be strong competitors during periods of low nutrient input. In many meromictic lacustrine systems, with annual stratification and stagnation, diatom blooms occur commonly during spring circulation when surface waters are recharged with nutrients from anoxic bottom waters. Under these conditions, Peridinium may bloom, with a biomass larger than warranted by nutrient conditions, and they may replace diatoms as the dominant species during the summer stagnation when nutrient levels are low. If we apply this generalized model to an euxinic Albian sea, the following salient features emerge. The rapid fluctuations in phytoplankton populations could result from alternating periods of basinwide stagnation and periods of partial to full circulation. After long periods of stagnation, overturn and mixing of nutrient-rich waters cause phytoplankton blooms. Possibly during initial phases of surplus nutrients, coccolith or radiolarian assemblages may be favored depending on the local levels and types of nutrient supply. If some dinoflagellate blooms are more closely associated with episodes of stagnation, they may be preferentially preserved in sediments because of the higher pyncnocline at those times. Dinoflagellates, although more sparse, are also wellpreserved in some green clays with low organic content. Perhaps these are also times with widespread anoxia but overall low productivity. Because currents and oxygenation continue in surface waters, the distribution of refractory land-derived components would be less affected by the episodic stagnation. Some dinoflagellate blooms possibly even caused widespread red tides as in the modern ocean. Naturally, oceans are a complex biological and chemical system, and the rapid sediment variations may only indicate subtle changes in the balance of populations at the surface and their survival as particles falling through the water column.

\section{SYSTEMATICS}

Only a few remarks are made concerning the morphology, systematics, and taxonomy of the palynomorphs. Except for one new species, formal descriptions are not given for several palynomorphs which are probably new for the middle Cretaceous. Most of these forms are very rare and only a few isolated examples of these species have been found. Informal designations are used in this publication. These species will be the subject of a later paper.

\section{ACKNOWLEDGMENTS}

Our thanks go to Urs Gerber for the excellent plates and Frl. H. Deubelbiss for preparation of samples. Michael Arthur, Rob Fensome, and William Orr are gratefully acknowledged for their thoughtful reviews and suggestions on the manuscript. This research was supported jointly by the Swiss National Fund and a Swiss Federal Institute of Technology (ETH) research grant. 


\section{REFERENCES}

Brenner, G. J., 1963. The spores and pollen of the Potomac Group of Maryland. Maryland Dept. Geol. Mines Water Res., v. 27, pp. $1-215$.

1976. Middle Cretaceous floral provinces and early migrations of Angiosperms. In Beck, C. B., (Ed.), Origin and Early Evolution of Angiosperms, pp. 23-47, New York and London (Columbia University Press).

Deroo, G., Herbin, J. P., Roucaché, J., Tissot, B., Albrecht, P., and Schaeffle, J., 1978. Organic geochemistry of some Cretaceous black shales from Sites 367 and 368; Leg 41, Eastern North Atlantic. In Lancelot, Y., Seibold, E., et al., Initial Reports of the Deep Sea Drilling Project, v. 41: Washington (U.S. Government Printing Office), pp. 865-871.

Doyle, J. A., 1969. Cretaceous angiosperm pollen of the Atlantic Coastal Plain and its evolutionary significance. J. Arnold Arbor, v. 50, pp. 1-35.

Doyle, J. A. and Robbins, E. I., 1977. Angiosperm pollen zonation of the Continental Cretaceous of the Atlantic Coastal Plain and its application to deep wells in the Salisbury Embayment. Palynology, v. 1, pp. 43-78.

Groot, J. J. and Groot, C. R., 1962. Plant microfossils from Aptian, Albian and Cenomanian deposits of Portugal. Communic. Serv. Geol. Portugal, v. 46, pp. 133-176.

Habib, D., 1972. Dinoflagellate stratigraphy Leg 11, Deep Sea Drilling Project. Initial Reports of the Deep Sea Drilling Project, v. 11: Washington (U.S. Government Printing Office), pp. $367-425$.

, 1975. Neocomian dinoflagellate zonation in the western North Atlantic. Micropaleontology, v. 21, pp. 373-392.

_ 1977 . Comparison of Lower and Middle Cretaceous palynostratigraphic zonations in the western North Atlantic. In Swain, F. M., Stratigraphic micropaleontology of Atlantic basin and borderlands. Develop. Paleont. Stratigraphy, v. 6, pp. 341-367.

Harker, S. D. and Sarjeant, W. A. S., 1975. The stratigraphic distribution of organic-walled dinoflagellate cysts in the Cretaceous and Tertiary. Rev. Paleobot. Palynol., v. 20, pp. 217. 315 .

Hedlund, R. W., 1966. Palynology of the Red Branch Member (Woodbine Formation), Oklahoma Geol. Surv. Bull., v. 112.

Herngreen, G. F. W., 1973. Palynology of Albian-Cenomanian strata of borehole 1-QS-1-MA, State of Maranhao, Brazil. Pollen et Spores, v. 15, pp. 515-555.

, 1974. Middle Cretaceous palynomorphs from Northeastern Brazil. Sci Geol. Bull., v. 27 (1-2), pp. 101-116. , 1975. An upper Senonian pollen assemblage of borehole 3-PIA-10-A1, State of Alagoas, Brazil. Pollen et Spores, v. 17, pp. 93-140.

Jardiné, S. and Magloire, L., 1965. Palynologie et stratigraphie du Crétacé des bassins du Sénégal et de Côte d'Ivoire. Mém. B.R.G.M., v. 32, pp. 187-245.

Kemp, E. M., 1968. Probable angiosperm pollen from British Barremian to Albian strata. Palaeontology, v. 11, pp. 421-434.

Krutzsch, W., 1970. Die stratigraphisch verwertbaren Sporen-und Pollenformen des mitteleuropäischen Alttertiärs. Jb. Geol., v. 3 (1967), pp. 309-379.

Lancelot, Y., Hathaway, J. C., and Hollister, C. D., 1972. Lithology of sediments from the western North Atlantic, Leg 11, DSDP. In Hollister, C. D., Ewing, J. I., et al., Initial Reports of the Deep Sea Drilling Project, v. 11: Washington (U.S. Government Printing Office), pp. 901-949.

Mädler, K. A., 1967. Tasmanites und verwandte Planktonformen aus dem Posidonienschiefer-Meer. Proc. 1. Int. Conf. Plankton. Microfoss., v. 2, pp. 375-377.
Morgan, R., in press. Albian to Senonian palynology of Site 367, Angola Basin. Initial Reports of the Deep Sea Drilling Project, v. 40: Washington (U.S. Government Printing Office).

Montadert, L., Roberts, D., et al., 1976. Glomar Challenger sails on Leg 48. Geotimes, v. 21, pp. 19-22.

Muller, J., 1970. Palynological evidence on early differentiation of angiosperms. Bio. Rev., v. 45, pp. 417-450.

Ryan, W. B. F. and Cita, M. B., 1977. Ignorance concerning episodes of ocean-wide stagnation. Mar. Geol., v. 23, pp. 197, 215.

Sclater, J. G., Hellinger, S., and Tapscott, C., 1977. The paleobathymetry of the Atlantic Ocean from the Jurassic to the present. J. Geol., v. 85, pp. 509-552.

Singh, C., 1971. Lower Cretaceous microfloras of the Peace River area, Northwestern Alberta. Res. Council Alberta, v. 28.

Stover, L. E., 1964. Cretaceous ephedroid pollen from West Africa. Micropaleontology, v. 10, pp. 145-156.

Tissot, B., Durand, B., Espitalié, I., and Combaz, A., 1974. Influence of the nature and diagenesis of organic matter in the formation of petroleum. Amer. Assoc. Pet. Geol. Bull., v. 58, pp. 499-506.

van der Voo, R. and French, R. B., 1974. Apparent polar wandering for the Atlantic-bordering continents: Late Carboniferous to Eocene, Earth Sci. Reviews, v. 10, pp. 99-119.

van Hinte, J. E., 1976. A Cretaceous time scale. Amer. Assoc. Pet. Geol. Bull., v. 60, pp. 498-516.

\section{APPENDIX \\ List of Spores and Pollens}

Spores

Aequitriradites sp.

(Plate 1, Figure 1)

A similar form named (but not formally described) Aequitriradites sp. is known from the Albian of Africa (Jardiné and Magloire, 1965).

Appendicisporites problematicus (Burger) Singh, 1971.

(Plate 1, Figures 2, 3)

Stratigraphic distribution: Berriasian-Albian.

Appendicisporites tricornitatus Weil. and Greif., 1953

(Plate 1, Figures 4, 5)

Baculatisporites sp.

(Plate 1, Figures 6, 7)

Trilete spore, rounded triangular or round in outline. Ornamented with more or less isodiametric gemmae, baculae or blunt echinae. The sculpture is the same on the proximal and distal face. Trilete laesura simple, reaching the equator.

Biretisporites potoniaei Delc. and Sprum., 1955

(Plate 1, Figure 8)

Cicatricosisporites hallei Delc. and Sprum., 1955

(Plate 1, Figure 9)

Stratigraphic distribution: Early Cretaceous and Cenomanian.

Cicatricosisporites minutaestriatus (Bolkh.) Pocock, 1964

(Plate 1, Figures 12, 13)

Cicatricosisporites mohrioides Delc. and Sprum., 1955

(Plate 1, Figures 10, 11)

Stratigraphic distribution: Purbeckian-Albian.

Cicatricosisporites cf. patapscoensis Brenner, 1963

(Plate 1, Figures 14, 15)

The spores compared with $C$. patapscoensis found in our material are smaller than the typus. The typical $C$. patapscoensis is stratigraphically restricted to Zone II (Brenner, 1963).

Cicatricosisporites subrotundus Brenner, 1963

(Plate 1, Figures 16, 17)

Stratigraphic distribution: restricted to Zone II (Brenner, 1963). 
Cicatricosisporites venustus Deak, 1963

(Plate 1, Figures 21, 22)

Stratigraphic distribution: Barremian-Cenomanian/Turonian (Singh, 1971)

Concavisporites juriensis Balme, 1957

(Plate 2, Figures 9, 10)

Stratigraphic distribution: Late Jurassic-Early Cretaceous

Converrucosisporites platyverrucosus Brenner, 1963

(Plate 1, Figures 19, 20)

In contrast to Baculatisporites (see forementioned), the sculptureelements are anisodiametric and the trilete laesura is bordered by an undulating crest. Stratigraphic distribution: Zones I and II (Brenner, 1963).

Converrucosisporites proxigranulatus Brenner, 1963

(Plate 1, Figure 18)

Costato perforosporites foveolatus Deak, 1962

(Plate 1, Figures 29, 30)

Stratigraphic distribution: Late Aptian-Albian (Singh, 1971)

Cyathidites australis Couper, 1953

Cyathidites minor Couper, 1953

Gleicheniidites circinidites (Cooks.) Dettm., 1963

(Plate 1, Figure 23)

Gleicheniidites confossus Hedlund, 1966

(Plate 1, Figures 24, 25)

Stratigraphic distribution: To date, has only been found in the Cenomanian.

Gleicheniidites echinatus (Bolkh.) W.Kr., 1959

(Plate 1, Figures 26-28)

Gleicheniidites sp. 1

(Plate 2, Figures 1, 2)

This species differs from the similar $G$. circinidites by the thick wall (about $5 \mu \mathrm{m}$ ) along the margin.

Klkisporites areolatus Singh, 1971

(Plate 2, Figures 4, 5)

Stratigraphic distribution: Albian (Singh, 1971)

Klukisporites foveolatus Pocock, 1971

(Plate 2, Figure 3)

Stratigraphic distribution: Barremian-Albian (Singh, 1971)

Psilatriletes circumundulatus Brenner, 1963

(Plate 2, Figures 6, 7)

Stratigraphic distribution: Zones I-II (Brenner, 1963),

Stereisporites antiquasporites (Wils. and Webst.) Dettm., 1963

(Plate 2, Figures 11-13)

Triplanosporites $\mathrm{sp} .1$

(Plate 2, Figures 18, 19)

This type of spore is very often found in different grain sizes.

Triplanosporites sp. 2

(Plate 2, Figure 8)

A species of the form-genus Triplanosporites with a flat coarse verrucate sculpture.

Undulatisporites cf. fossulatus Singh, 1971

(Plate 2, Figures 16, 17)

In contrast to the type $U$. fossulatus, the sides of the spores are not straight, but convex. The amb is rounded triangular. Stratigraphic distribution of the typical $U$. fossulatus: middle and late Albian (Singh, 1971).

Undulatisporites undulapolus Brenner, 1963

(Plate 2, Figures 14, 15)

Stratigraphic distribution: Barremian-Albian (Singh, 1971).

Trilete sp. 1

(Plate 2, Figures 20, 21)

Trilete spore with a rounded amb. Trilete laesurae straight, short, not reaching the equator. Sculpture irregular reticulate, lumen 1 to $3 \mu \mathrm{m}$ in diameter. Muri inhomogeneous, compose of small elements. Occurrence: single spore found in Sample 418B-31-2, 11-13 cm.

Trilete sp 2

(Plate 2, Figures 22, 23)
Trilete spore, amb round to rounded triangular. Sculpture verrucate. The high verrucae are interconnected by low irregular bridges forming an indistinct reticulum. Trilete laesurae straight, not reaching the equator. Occurrence: single spore found in Sample 417D-21-1, 108-110 cm.

\section{Gymnosperms \\ Vesiculate Grains}

Alisporites thomasi Couper, 1958

(Plate 2, Figures 24, 25)

Cedripites admirabilis (Bolkh.) W.Kr., 1971

(Plate 3, Figures 3-5)

Parvisaccites radiatus Couper, 1958

(Plate 2, Figures 31, 32)

Parvisaccites rugulatus Brenner, 1963.

(Plate 2, Figure 29)

Podocarpidites multesimus (Bolkh.) Pocock, 1962

(Plate 3, Figures 1, 2)

Rugubivesiculites minimus Burger, 1966

(Plate 2, Figure 30)

Vitreisporites pallidus (Reiss.) Nilss., 1958

(Plate 2, Figures 26-28)

In our material the grains of $V$. pallidus are highly variable in size (20 to $40 \mu \mathrm{m})$.

\section{Classopollis-Exesipollenites-Form Group}

Classopollis brasiliensis Herngreen, 1975

(Plate 3, Figures 10, 11)

Classopollis noeli Reyre, 1970

(Plate 3, Figures 6-9)

The most frequent species of Classopollis can be compared best with $C$. noeli. The grains found in our material are highly variable in size ( 20 to 40 $\mu \mathrm{m})$. The ornamentation is, in contrast to $C$. brasiliensis, isodiametric verrucate.

Classopollis spinosus Herngreen, 1973

(Plate 3, Figures 18, 19)

Exesipollenites tumulus Balme, 1957

(Plate 3, Figures 12, 13)

Besides the distal "pore," several specimens show a very fine trilete scar. Tetrads of $E$. tumulus are found very rarely (compare Plate 3, Figure 13).

Exesipollenites sp.

(Plate 3, Figure 14)

In contrast to $E$.tumulus, this species is smaller and shows a very small depression (diameter about $2 \mu \mathrm{m}$ ) within the thickened area of the distal pole.

\section{Inaperturate and Colpate Gymnosperms}

Araucariacites australis Cooks., 1947

(Plate 3, Figure 33)

Araucariacites cf. hungaricus Deak, 1965

(Plate 3, Figures 21, 22) from A. australis

This form can be distinguished by its coarser sculpture. A. hungaricus is known from the Cenomanian.

Callialasporites dampieri (Balme) Sukh Dev, 1961

(Plate 3, Figure 17)

Cerebropollenites mesozoicus (Couper) Nilsson, 1958

(Plate 3, Figure 20)

Cycadopites minimus (Cooks., 1947)

(Plate 3, Figure 15)

The species has been described as Monosulcites minimus. The genus Monosulcites is a synonym of Cycadopites Wdh., 1933 (ex Wilson and Webster, 1946).

Cycadopites carpentieri (Del. and Sprum.)

(Plate 3, Figure 16)

C. carpentieri differ from C. minimus by the size (about $70 \mu \mathrm{m}$ ) and the coarser structure. 
Cycadopites sp. 1

(Plate 3, Figures 24, 25)

This pollen grain, with a relatively thick structured (granulate) wall and a wide colpus, can be compared with the specimen of Jardiné and Magloire (1965; Pl. 9, fig. 14) named Monosulcites sp. from the Albian-Aptian.

Eucommiidites troedssonii (Erdtm.) R. Pot., 1958

(Plate 3, Figures 31, 32)

Eucommiidites? glottus (Brenner, 1963)

(Plate 3, Figure 23)

Brenner described a similar form as Monosulcites glottus. It is possible that the two folds beside the main sulcus of the holotypus correspond to the reduced colpi of Eucommiidites.

Eucommiidites sp. 1

(Plate 3, Figures 27, 28)

Tricolpate grain with one big and two smaller colpi. In contrast to the typical $E$. troedssonii, this grain is considerably larger $(52 \mu \mathrm{m})$. The ectexine is about $2 \mu \mathrm{m}$ thick at the equator with a thickening trend toward the pole. The endexine is thin. The structure shows the typical granulation of the gymnosperms.

Inaperturopollenites hiatus (R.Pot.) Th. and Pf., 1953

(Plate 3, Figure 26)

The first occurrence of this form lies in the middle Albian.

Sciadopityspollenites sp. 1

(Plate 3, Figures 29, 30)

The structure and sculpture of this inaperturate grain correspond to the genus Sciadopityspollenites, for example to $S$. crassus from European Tertiary. According to W. Krutzsch (1970), Sciadopityspollenites first occurs in the Late Cretaceous. Cerebropollenites mesozoicus, resembling Sciadopityspollenites, has a coarser sculpture and a different structure. $C$. mesozoicus is very frequent in the Jurassic and in the Early Cretaceous.

\section{Ephedroide Pollen Grains}

Aucmancisporites cf. cretaceous (Pocock) Pocock, 1964

(Plate 4, Figure 1)

The single grain found in the material of Hole $418 \mathrm{~A}$ is smaller than the holotype. Distinctive for the genus is the transverse colpus.

Ephedripites (Distachyapites) cf. markovii (Pocock, 1964)

(Plate 4, Figures 4, 5)

Ephedripites (Distachyapites) cf. mediolobatus Bolkh., 1953

(Plate 4, Figures 14, 15)

Ephedripites (Distachyapites) multistriatus (Pocock, 1964)

(Plate 4, Figure 2)

Ephedripites (Distachyapites) sp. 2 - Herngreen (1973)

(Plate 4, Figures 8, 9)

Small grains (about $40 \mu \mathrm{m}$ ) with numerous fine ribs separated by fine grooves. It is possible that they have a sulcus-like area without sculpture. Stratigraphic distribution: Albian-Cenomanian (Herngreen, 1973)

Ephedripites (Distachyapites) sp. 4 - Herngreen (1973)

(Plate 4, Figure 13)

Relatively large grain with about 15 coarse ribs separated by wide grooves. Stratigraphic distribution: as $E$. sp. 2.

Ephedripites (Distachyapites) sp. 5 - Herngreen (1973)

(Plate 4, Figure 3)

Small grain with numerous (15) about $2 \mu \mathrm{m}$ broad ribs. The grooves in between are very fine. Stratigraphic distribution: as $E$. sp. 2 and 5.

Ephedripites (Spiralipites) barghoornii (Pocock, 1964)

(Plate 4, Figures 6, 7)

Stratigraphic distribution: In the material from the mid-Cretaceous of South America (Herngreen, 1975) E. barghoornianum, staplinii and E. jansonii are frequent in the Albian and disappear in the Cenomanian.

Ephedripites (Spiralipites) jansonii (Pocock, 1964) Müller, 1968 (Plate 4, Figure 12)

Ephedripites (Spiralipites) staplinii (Pocock, 1964)

(Płate 4, Figures 10, 11)

Steevesipollenites binodosus Stover, 1964

(Plate 4, Figures 29, 30)

Stratigraphic distribution: Albian-Turonian (Stover, 1964)
Steevesipollenites $\mathrm{cf}$. binodosus Stover, 1964

(Plate 4, Figures 16; 22, 23)

The distal ends of these grains are also thickened but less prominent than in the type St. binodosus. Ribs numerous (15 to 20); grooves narrow.

Steevesipollenites multilineatus Stover, 1964

(Plate 4, Figures 18 through 21)

Stratigraphic distribution: Albian-Turonian (Stover, 1964; Herngreen, 1973).

Steevesipollenites $\mathrm{sp} .1$

(Plate 4, Figure 17)

Large grain (about $100 \mu \mathrm{m}$ ) with thickened ends and numerous coarse ribs (about 24). Grooves between them are rather wide and flat. This form can be compared with Ephedripites sp. 7 - Herngreen (1973), which is about $130 \mu \mathrm{m}$ in diameter.

Steevesipollenites $\mathrm{sp} .2$

(Plate 4, Figure 28)

Small grain with thick end and more than 30 fine ribs. Grooves as broad as the ribs.

Welwitschiapites sp. 1

(Plate 4, Figures 24, 27)

The grains assigned to Welwitschiapites sp. have numerous ribs (15 to 20) and one longitudinal furrow accompanied by two more solid ribs. Under the other ribs the endexine seems to be folded, producing a crossstriped ornamentation on the ribs. The ribs merge at the distal ends. The ectexine is thickened but, in contrast to Steveesipollenites, the two layers are still recognizable. $W$. sp. 1 is comparable in general features with $W$. virgatus Deak 1964, but this species is larger and shows no ornamentation of the ribs.

\section{Elaters-Bearing Species}

Elaterosporites klaszi (Jard. and Magl.) Jard., 1967

(Plate 5, Figures 1,2)

Stratigraphic distribution: Albian-Cenomanian (Herngreen, 1975).

\section{Angiosperms}

Arecipites sp. 1

(Plate 5, Figures 3-5)

Slightly asymmetric monocolpate grain. Sculpture fine reticulate, homobrochate, lumen about $1 \mu \mathrm{m}$ in diameter. Structure densely columellate. Arecipites can be distinguished from Liliacidites by its smaller size and by the density of the reticulum. A similar form has been described as Liliacidites sp. B by Doyle and Robbins, 1977.

Arecipites sp. 2

(Plate 5, Figures 6, 7)

This form can be distinguished from $A$. sp. 1 by the narrow colpus, very fine reticulum, and extremely dense structure.

Clavatipollenites hughesii Couper, 1958

(Plate 5, Figures 10-12; 19, 20)

Stratigraphic distribution: Zones I-III (Doyle and Robbins, 1977).

Clavatipollenites tenellis Phillips and Felix, 1971

(Plate 5, Figures 15, 16)

Stratigraphic distribution: as $C$. hughesii.

Magnolipollis sp. 1

(Plate 5, Figures 13, 14)

Monocolpate grain with a narrow colpus. Wall about $1 \mu \mathrm{m}$ thick, twolayered, endexine very thin. Structure columellate, sculpture punctate or very fine reticulate. This form can be compared with Magnolipollis magnolioides W.Kr., 1970 known from the European Tertiary.

Monocolpopollenites cf. tranquillus tranquillus (R.Pot.) Th. and Pf., 1953 (Plate 5, Figures 8, 9)

Monocolpate grain with smooth to fine punctate surface. Structure fine columellate. This form can best be compared with $M$. tranquillus, a species related to the Palmae occurring in the Paleogene.

Monocolpopollenites $\mathrm{cf}$. tranquillus verrucatus W.Kr., 1962a

(Plate 5, Figures 17, 18)

This type can be distinguished from the former species by the characteristic verrucate sculpture. A very similar subspecies of $M$. tranquillus occurs in the European Tertiary. 
Milfordia sp. 1

(Plate 5, Figures 21, 22)

Monoporate grain; pore of irregular shape. Wall thin (about $1.5 \mu \mathrm{m}$ ), two-layered, structure hardly visible. Sculpture scorbiculate (tectum perforate), surface smooth. This pollen grain can best be compared with the fossil genera Milfordia Erdtm., 1960 and with the pollen of recent Restionaceae.

Monocolpate sp. A

(Plate 5, Figures 25-27)

Monocolpate grain with a distinct colpus surrounded by an anulus-like zone without sculpture. Wall about $2 \mu \mathrm{m}$ thick, ectexine thicker than endexine. Sculpture scorbiculate (tectum perforate), distance between the scorbiculae 1 to $2 \mu \mathrm{m}$. Structure columellate, elements grown together forming an irregular intrareticulum. The grain can be compared with the pollen grains of the recent monocots families Restionaceae and Centrolepidaceae.

Monocolpate sp. B

(Plate 5, Figures 23, 24)

Monocolpate grain with a long colpus which extends over more than $180^{\circ}$ of the pollen grain. Wall thin (about $1 \mu \mathrm{m}$ thick), two-layered $(r \sim$ 1:1). Structure not visible. Sculpture scorbiculate (tectum perforate), distribution of the scorbiculae irregular.

"Trichotomosulcites" Erdtm., 1945 sp. 1

(Plate 5, Figures 28-31)

Trichotomocolpate grain. Sculpture reticulate, homobrochate, lumen about $2 \mu \mathrm{m}$ in diameter, muri $1 \mu \mathrm{m}$, monobaculate, baculae thickens toward the top (diameter at the top $1 \mu \mathrm{m}$ ). Endexine very thin, less than 1 $\mu \mathrm{m}$. This form can be compared with the pollen grains of recent palms (for example Acanthorhiza, Erdtman [1971, fig. 177 C]).

"Trichotomosulcites" sp. 2

(Plate 5, Figures 35-37)

Trichotomocolpate grain. Colpus accompanied by a folding of the wall. Wall two- layered $(r \sim 1: 1)$. Elements of structure grown together, forming an irregular network. Surface smooth.

\section{Retimonocolpites Pierce}

This genus can be distinguished from similar forms of the genus Liliacidites by the long colpus encircling the grain and by the reticulum which is connected with the endexine by scattered columellae. The reticulum is very often partly separated from the grain. Retimonocolpites has been regarded as synonymous with Liliacidites by Kemp (1968).

Retimonocolpites dividuus Pierce, 1961

(Plate 5; 6 Figures 32-34; 1-3)

Reticulum fine, more or less regular (hombrochate), lumen 1 to $2 \mu \mathrm{m}$ in diameter. The reticulum is attached to the endexine with about one columella per brochus. In our material this form can be observed relatively often in different grain sizes (20 to $35 \mu \mathrm{m}$ ). Stratigraphic distribution: Zones IIA-III (Doyle and Robbins, 1977).

Retimonocolpites clavatus (Singh, 1971)

(Plate 6, Figures 4-6; 7,8)

In contrast to $R$. dividuus, the reticulum of $R$. clavatus is heterobrochate and there are several distally thickened columellae per brochus. Stratigraphic distribution: late Albian (Singh, 1971).

Retimonocolpites enchinatus n.sp.

(Plate 6, Figures 9-11)

$R$. echinatus differ from other forms of the genus by its echinate ornamentation of the reticulum. The latter is held by about one columella per brochus. The columellae are distally thickened. The echinate ornamentation is not in connection with the columellae. About 10 echinae of $1 \mu \mathrm{m}$ length can be observed on one brochus.

Retimonocolpites peroreticulatus (Brenner) Doyle, 1975

(Plate 6, Figures 14, 15)

In this species the reticulum is heterobrochate (diameter of the lumen 1 to $4 \mu \mathrm{m}$ ). The muri of the reticulum are relatively broad ( $1 \mu \mathrm{m}$ or more) and inhomogeneous in structure. Stratigraphic distribution: Zones I-III (Doyle and Robbins, 1977).

Retimonocolpites cf. peroreticulatus (Brenner) Doyle, 1975

(Plate 6, Figures 12, 13)

This form can be distinguished from the typical $R$. peroreticulatus by the size $(40$ to $50 \mu \mathrm{m})$, by the coarse irregular reticulum (lumen diameter about $5 \mu \mathrm{m})$ and the large distance between the endexine and the reticulum. A similar grain has been described by Brenner (1968) as Reticulatisporites jardinus.

Retimonocolpites reticulatus (Brenner, 1963)

(Plate 6, Figures 16, 17; 18-20)

In this species the muri are very narrow and the reticulum is attached by several ( 4 to 6 ) pilae per brochum. The lumina of the reticulum are of irregular form and size. Stratigraphic distribution: Barremian-Albian (Singh, 1971).

Striatopollis dubius (Jard. and Magl.) Morgan, 1978

(Plate 6, Figures 27-29)

Stratigraphic distribution: Albian (Morgan, 1978).

Tricolpites albiensis Kemp, 1968

(Plate 6, Figures 32, 33)

Stratigraphic distribution: Zones IIA-IIC (Doyle and Robbins, 1977)

Tricolpites cf. barrandei Paclt., 1971

(Plate 6, Figures 30, 31)

Stratigraphic distribution: Zone III (Doyle and Robbins, 1977).

Tricolpites crassimurus (Groot and Penny) Singh, 1971

(Plate 6, Figures 21-24)

First occurrence: Zone II (Doyle and Robbins, 1977).

Tricolpites nemejci Paclt., 1971

(Plate 6, Figures 38, 39)

Stratigraphic distribution: Zone III (Doyle and Robbins, 1977)

Tricolpites parvulus (Groot and Penny, 1960)

(Plate 6, Figures 34, 35)

First occurrence: Zones IIA-III (Doyle and Robbins, 1977).

Tricolpites cf. parvulus (Groot and Penny, 1960)

(Plate 6, Figures 25, 26)

Tricolpate grain, colpae narrow, somewhat larger in the equatorial region. Cavernae well-developed. Wall thin (about $1 \mu \mathrm{m}$ ), endexine thinner than ectexine. These grains are larger than the typical $T$. parvulus (about 30 $\mu \mathrm{m}$ instead of 20 to $25 \mu \mathrm{m})$.

Tricolpites sagax Norris, 1967

(Plate 6, Figures 45, 46)

Stratigraphic distribution: Zones IIA-III (Doyle and Robbins, 1977).

Tricolpites sp. 1

(Plate 6, Figures 36, 37)

Tricolpate grain with distinct cavernae. Wall thin (about $1 \mu \mathrm{m}$ ). Structure densely baculate, sculpture punctate.

"Tricolpopollenites" macroreticulatus Groot and Groot, 1962

(Plate 6, Figures 40, 41)

Stratigraphic distribution: upper Albian-lower Cenomanian.

"Tricolpopollenites" pumilis Groot, Penny, and Groot, 1961

(Plate 6, Figures 42-44)

\section{Proximate Dinoflagellate Cysts}

Canningia colliveri Cooks, and Eisenack, 1960

(Plate 7, Figure 1)

First occurrence: upper Barremian (Harker and Sarjeant, 1975).

Canningia rotunda Cooks. and Eisenack, 1961

(Plate 7, Figure 2)

A similar form has been described as Archeotectatum sarjeantii Habib (1972) from the Late Jurassic of Leg 11.

Canningia circularis Cooks. and Eisenack, 1971

(Plate 7, Figures 3,5)

Stratigraphic distribution: this species is known from mid-Cretaceous of Australia.

Cribroperidinium muderongensis (Cooks. and Eisenack) Davey, 1969

(Plate 7, Figure 4)

Stratigraphic distribution: Berriasian-Aptian.

Cribroperidinium orthoceras (Eisenack) Davey, 1969

Cribroperidinium sp. 1

(Plate 7, Figures 6, 7; 9, 10)

The arrangement and the number of the plates correspond with those of the genus Cribroperidinium. Theca oval or rounded with one apical and one more or less, prominent antapical horn. Tabulation reflected by irregular vermiculate ridges. Cingulum slightly helicoid. 
Diacanthum hollisteri Habib, 1972

(Plate 7, Figure 8)

Stratigraphic distribution: After Habib (1977), this species is restricted to the Neocomian. In our material is occurs regularly in the entire profile.

Dictyopyxidia reticulata (Valensi) Lentin and Williams, 1973

(Plate 7, Figure 11)

Druggidium deflandrei (Millioud) Habib, 1973

(Plate 7, Figure 18)

Fromea amphora Cooks. and Eisenack, 1958

(Plate 7, Figures 22, 23)

Stratigraphic distribution: Barremian-Cenomanian.

Ginginodinium spinulosum Cooks. and Eisenack, 1960

(Plate 7, Figures 14-17)

Stratigraphic distribution: Albian-Cenomanian (Harker and Sarjeant, 1975).

Gonyaulacysta helicoidea (Eisenack and Cooks.) Sarjeant, 1966b

Gonyaulacysta ordovaca Duxbury, 1977

(Plate 8, Figures 5, 6)

Leptodinium cf. aculeatum Wall, 1967

(Plate 7, Figures 20, 21)

Leptodinium alectrolophum Sarjeant, 1966

(Plate 8, Figures 11, 12)

Leptodinium cf. margaritiferum (Cooks. and Eisenack) Sarjeant, 1969

(Plate 8, Figure 3)

Meiourogonyaulax psoros Davey and Verdier, 1974

(Plate 7, Figure 19)

Stratigraphic distribution: Hauterivian-Albian (Harker and Sarjeant, 1975).

Palaeoperidinium sp.

(Plate 8, Figure 4)

This form can be assigned to the genus Palaeoperidinium. The theca is rounded pentagonal with one prominent apical horn. The cingulum is helicoid. A tabulation is hardly visible. Dorsal archeopyle polygonal; ornamentation punctate. First occurrence of the genus: Albian (Harker and Sarjeant, 1975).

cf. Pyxidiella sp.

(Plate 7; 8, Figures 12, 13; 1, 2)

Ovoidal or spherical body with a subapical archeopyle, which is more or less rectangular. The thin wall is ornamented with blunt echinae which are of different sizes from one specimen to another ( 2 to $5 \mu \mathrm{m}$ ). Cingulum or tabulation not visible.

"Scriniodinium attadalense" (Cooks. and Eisenack) Eisenack, 1967

(Plate 8, Figures 7, 8)

Similar forms from the Lower Cretaceous of Leg 11 have been assigned to $S$. attadalense by Habib (1975). Stratigraphic distribution: Valanginian-Cenomanian (Habib, 1977).

\section{Proximo-Chorate Dinoflagellate Cysts}

Hystrichosphaeropsis ovum Defl., 1935

Spiniferites cingulatus (Wetzel, 1935) Sarjeant, 1970

First occurrence: upper Aptian (Harker and Sarjeant, 1975).

Spiniferites ramosus (Ehrenb.) Loeblich and Loeblich, 1966

\section{Chorate Dinoflagellate Cysts}

Cannosphaeropsis peridicta Eisenack and Cooks., 1960

(Plate 8, Figure 15)

Stratigraphic distribution: Aptian-Albian.

Chlamydophorella discreta Clarke and Verdier, 1967

(Plate 8, Figures 9, 10;18)

First occurrence: Cenomanian.

Cleistosphaeridium huguonioti (Valensi) Davey, 1969

(Plate 8, Figures 13, 14)

Stratigraphic distribution: occur regularly in the Albian and in the lower part of the Late Cretaceous.

Cometodinium sp.

(Plate 8, Figure 17)
Cyclonephelium distictum subsp. brevispinatum (Millioud) Lentin and Williams, 1973

(Plate 8, Figure 16)

Stratigraphic distribution: Berriasian-early Aptian (Harker and Sarjeant, 1975)

In our material the species occurs in the profile of Hole 417D.

Gardodinium deflandrei Clarke and Verdier, 1967

(Plate 8, Figure 23)

Stratigraphic distribution: Albian (Harker and Sarjeant, 1975).

Hystrichosphaeridium arundum Eisenack and Cooks., 1960

(Plate 8, Figure 22)

Stratigraphic distribution: Albian (Harker and Sarjeant, 1975).

Lithosphaeridium conispinum Davey and Verdier, 1973

(Plate 8, Figures 19, 20)

First occurrence: late Aptian.

Lithosphaeridium siphoniphorum (Cooks. and Eisenack) Davey and Williams, 1966

(Plate 8, Figure 26)

First occurrence: late Aptian.

Oligosphaeridium complex (White) Davey and Williams, 1966

Prolixosphaeridium granulosum (Defl. 1937) Davey et al., 1966

(Plate 8; 9, Figures 24, 25; 15)

A similar type has been described as Polysphaeridium warrenii by Habib (1975).

Prolixosphaeridium deirense Davey et al., 1966

(Plate 9, Figure 5)

Systematophora fasciculigera Klement, 1960

(Plate 9, Figure 6)

\section{Cavate Dinoflagellate Cysts}

Actinotheca aphroditae Cooks. and Eisenack, 1960

(Plate 8, Figure 21)

Stratigraphic distribution: To date this form has only been found in the Turonian of Australia.

Odontochitina operculata (Wetz.) Defl. and Cooks., 1955

(Plate 9, Figures 1, 2)

Palaeohystrichophora infusorioides Defl., 1935

(Plate 9, Figure 3)

First occurrence: middle Albian (Harker and Sarjeant).

Subtilisphaera perlucida (Alberti) Jain and Millepied, 1973

(Plate 9, Figure 7)

Stratigraphic distribution: After Habib (1977), this species is restricted to the Odontochitina operculata Zone (Barremian-early Albian). In our material it also occurs in the lower part of the floral Zone III (late Albianearly Cenomanian).

Xenikoon australis Cooks. and Eisenack, 1960

(Plate 9, Figures 4, 8)

A similar form has been registered as Pyxidiella sp. A by Habib (1972) from the Barremian and Aptian of DSDP Leg 11. X. australis is known from the Late Cretaceous of Australia.

Acritarchs, Tasmanaceae, and Cysts of Uncertain Affinity

Micrhystridium fragile Defl., 1947

(Plate 9, Figure 23)

Pterospermopsis helios Sarjeant, 1974

(Plate 9, Figure 20)

This species has been observed in highly variable sizes ( 40 to $85 \mu \mathrm{m}$ ).

Pleurozonaria sp. 1

(Plate 9, Figures 16, 17; 18, 19)

In our material the size of Pleurozonaria varies from 20 to $50 \mu \mathrm{m}$.

Tytthodiscus sp. 1

(Plate 9, Figures 9, 10)

We can distinguish two types of Tytthodiscus by their different sizes. $T$. sp. 1 is of about $35 \mu \mathrm{m}$ in diameter; the large form $T$. sp. 2 of about $80 \mu \mathrm{m}$.

Tytthodiscus sp. 2

(Plate 9, Figure 21) 
Tytthodiscus sp. 3

\section{(Plate 9, Figures 11, 12)}

A spheroid body with a thick homogeneous wall, very similar to Tythodiscus, has been found ornamented with scattered echinae of about $4 \mu \mathrm{m}$ length.

Monogemmites cf. pseudosetarius (Weyl. and Pf.) W.Kr., 1970

(Plate 9, Figures 13, 14; 24, 25)

A probable algal cyst very similar to Tythodiscus shows a regular gemmate to echinate ornamentation. It can be compared with Monogemmites pseudosetarius known from lacustrine sediments of the European Tertiary. Krutzsch (1970) attributes this form to a resting cyst of a freshwater algae. The same form can also be found in marine sediments of the Central Paratethys,

\section{Incertae Sedis}

Spermatites sp.

(Plate 9, Figure 22)

Our form from the Albian of Hole 417D looks similar to the material from the Cenomanian of Oklahoma (Hedlund, 1966) named Spermatites or the "lenticular bodies" from the Late Albian of Alberta (Singh, 1971). Another type resembling Spermatites has been described as Lancettopsis lanceolata by Mädler (1969) from the Jurassic.

\section{Microforaminifers}

(Plate 9, Figure 26)

Besides the planispiral microforaminifers found very frequently in our material, several forms with uni- or biserial arrangement of the chambers could be observed. 
APPENDIX A $i$

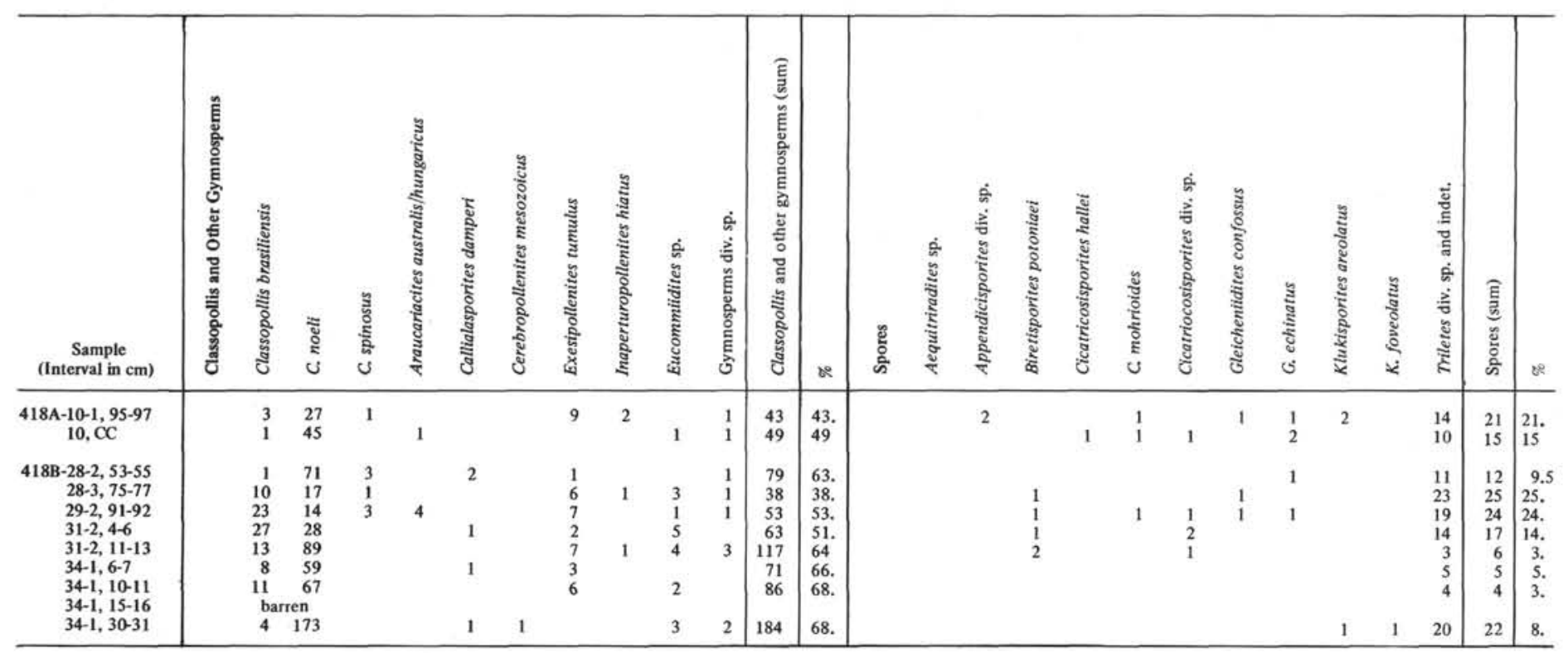

APPENDIX A $i i$

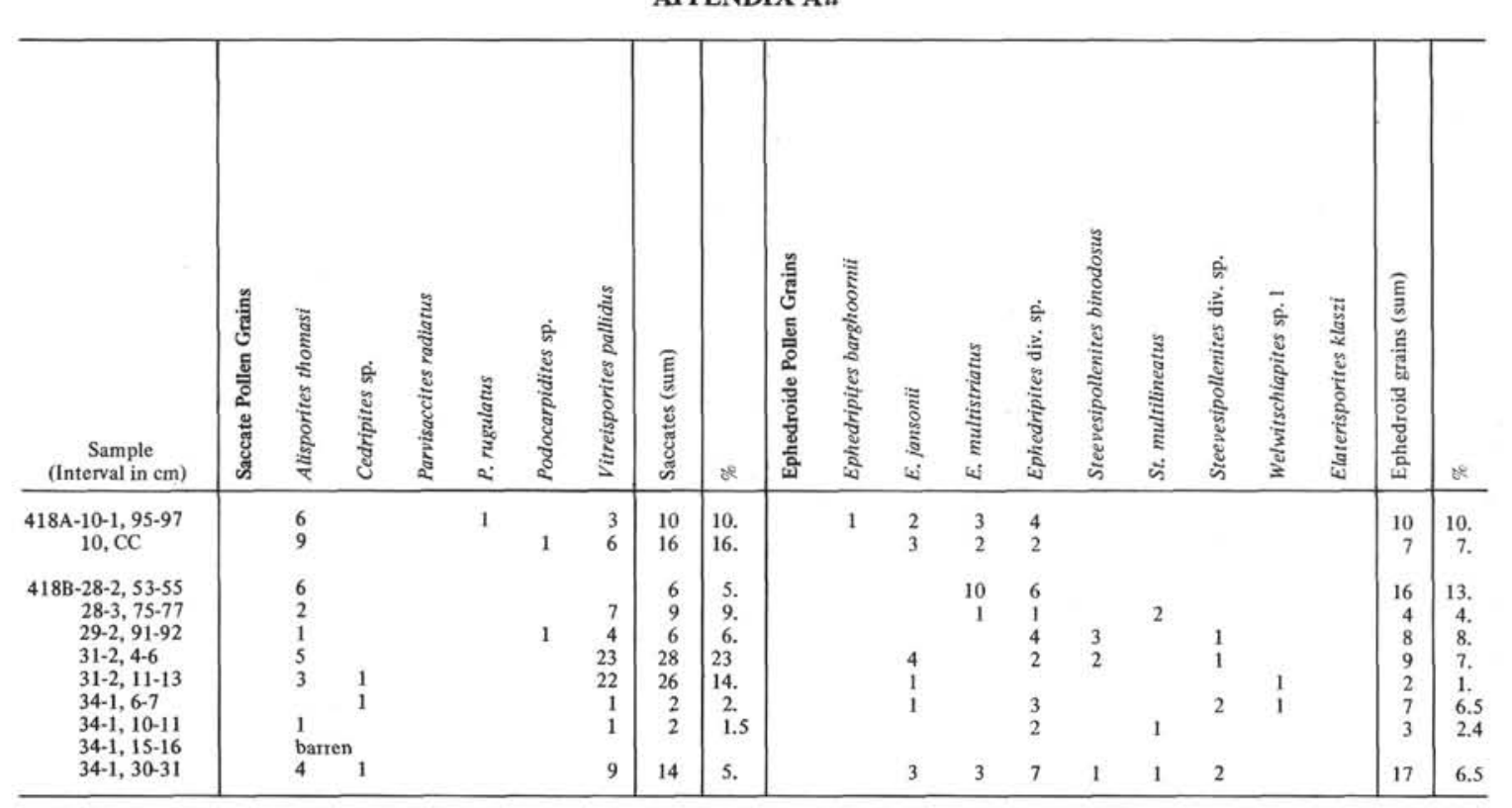




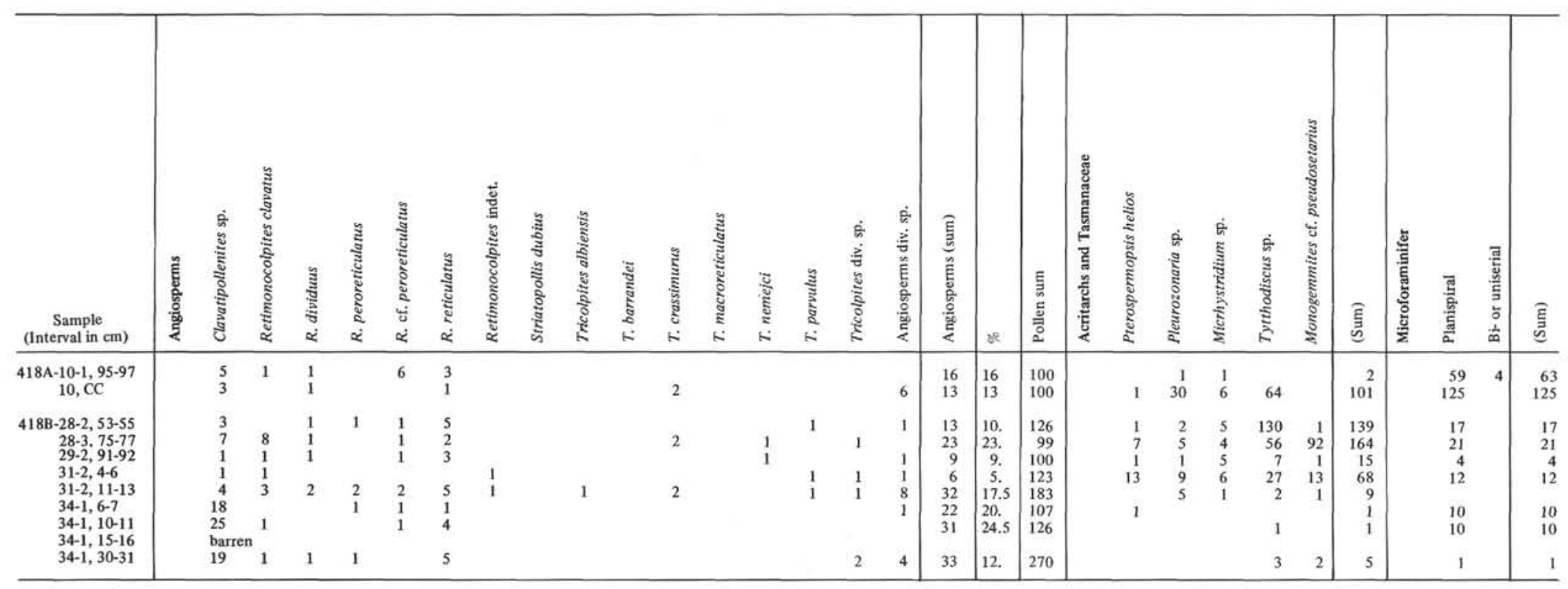

APPENDIX A $i v$

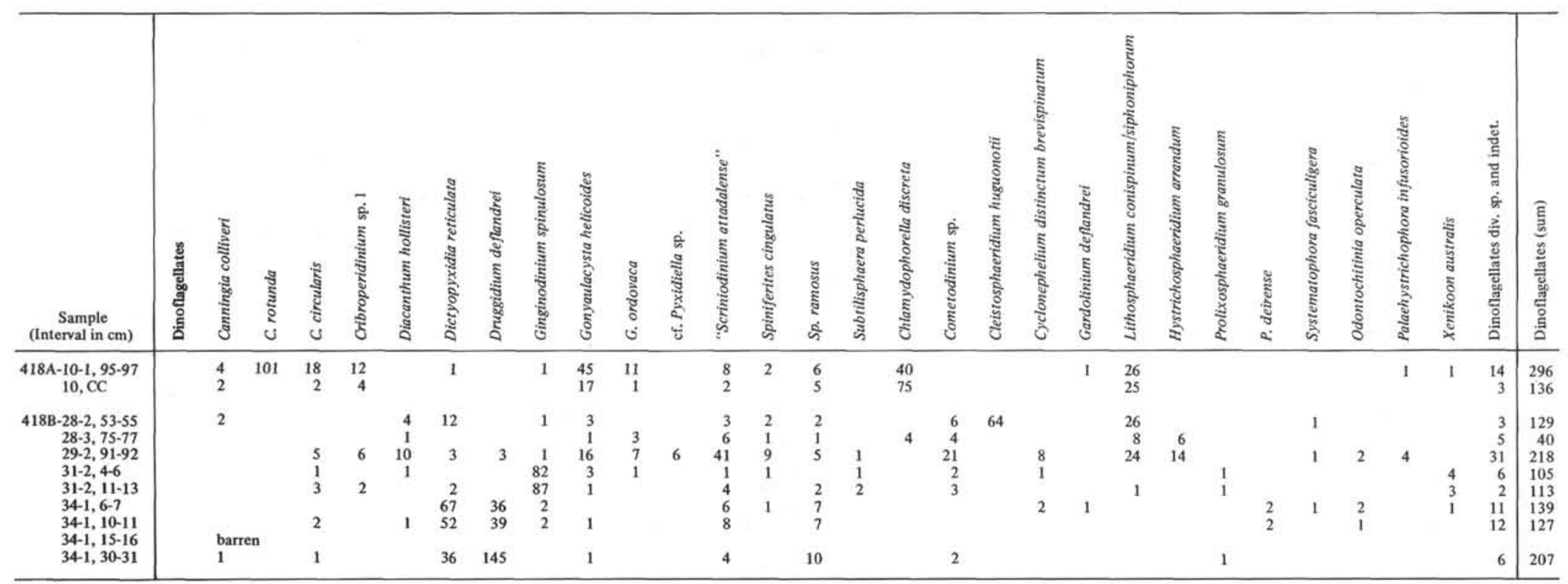


APPENDIX A $v$

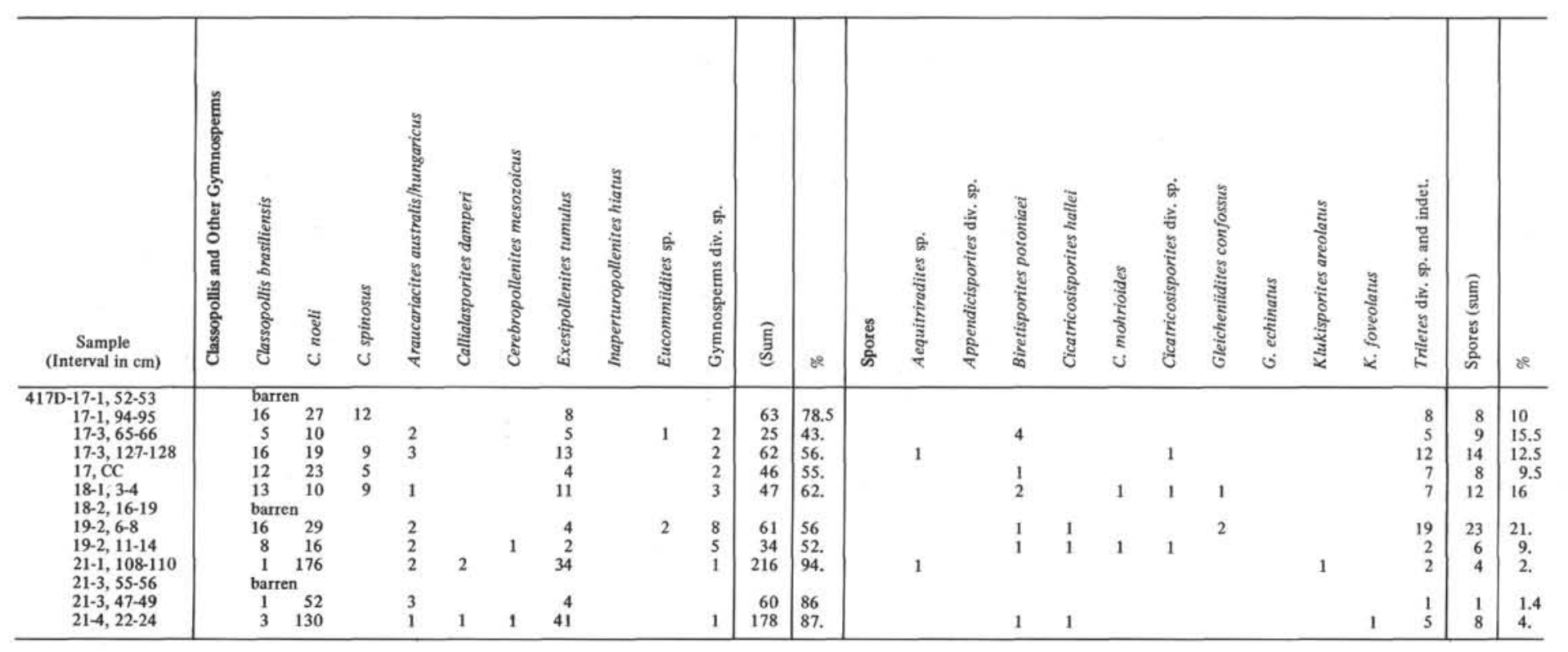

APPENDIX A $v i$

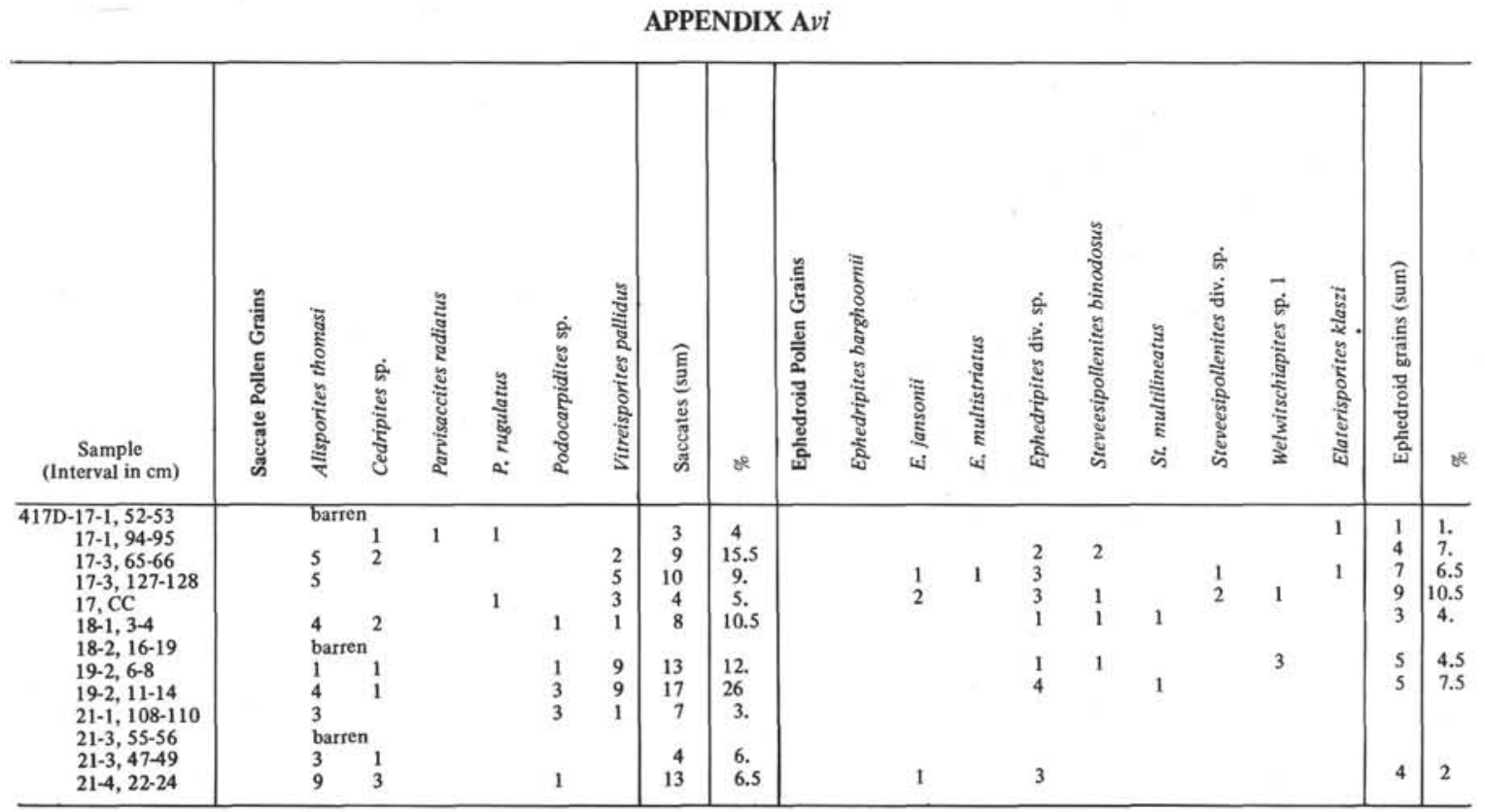




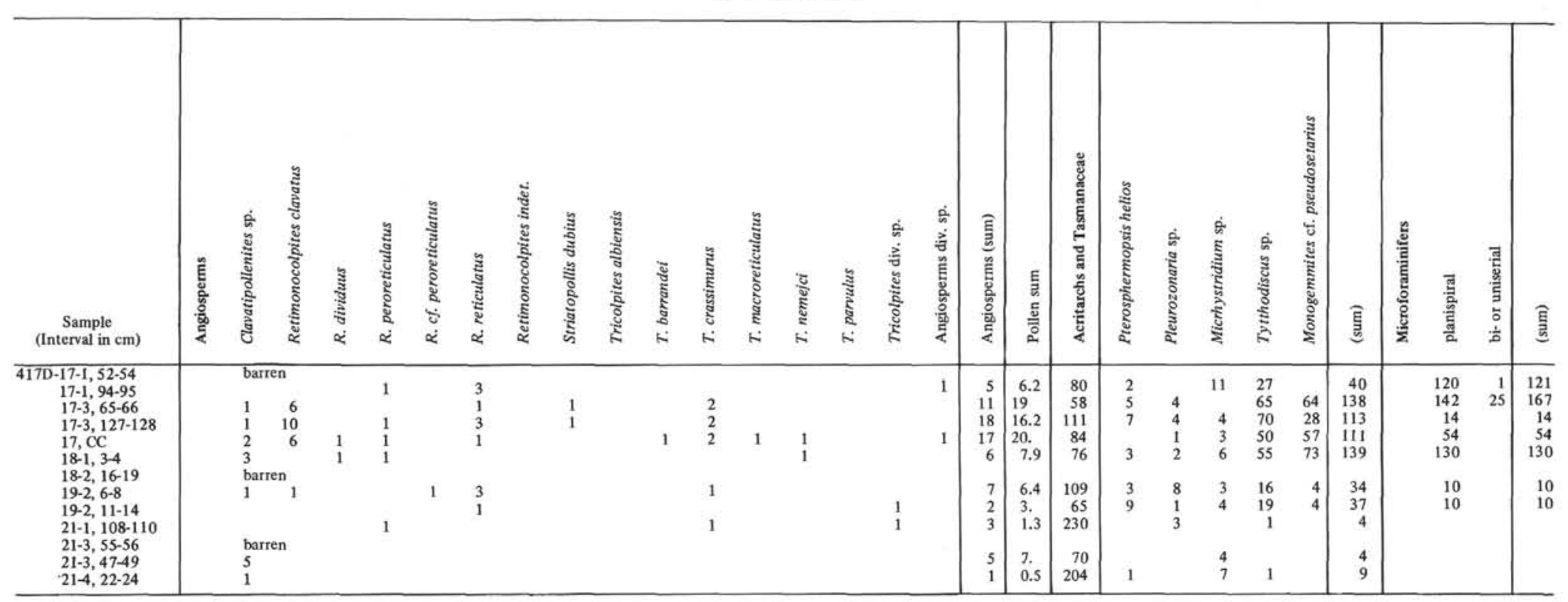

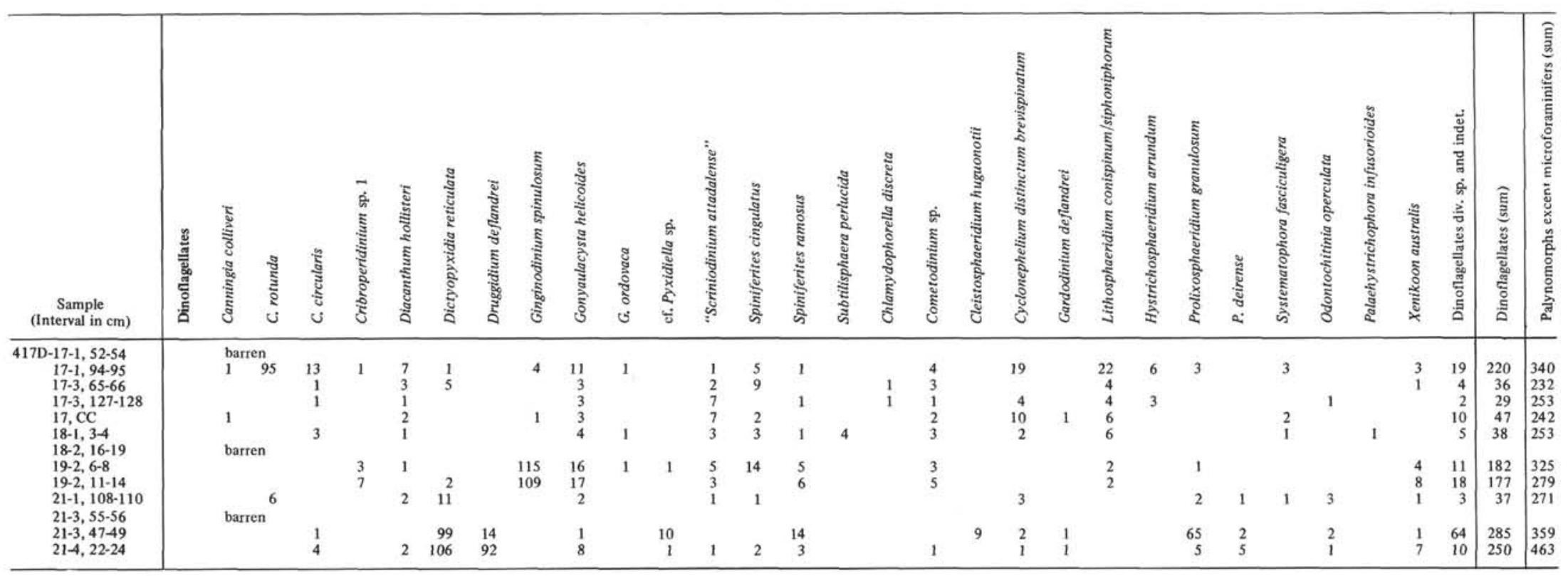



PLATE $\downarrow$

All figures $\times 750$ unless otherwise indicated.

Figure $1 \quad$ Aequitriradites sp.

Sample 417D-21-1, 108-110 cm (No. 1)

Figures 2, 3 Appendicisporites problematicus (Burger) Singh 1971.

Sample 418A-10-1, 95-97 cm (No. 4)

Figures 4, 5 Appendicisporites tricornitatus Weil \& Greif 1953. Sample 418A-10-1, 95-97 cm (No. 6)

Figures 6, 7 Baculatisporites $\mathrm{sp}$.

Sample 418B-31-2, 11-13 cm. (No. 4)

Figure $8 \quad$ Biretisporites potoniaei Delc. \& Sprum. 1955.

Sample 418B-31-4, 4-6 cm. (No. 8)

Figure 9 Cicatricosisporites hallei Delc. \& Sprum. 1955.

Sample 417D-19-2, 6-8 cm. (No. 7)

Figures 10, 11 Cicatricosisporites mohrioides Delc. \& Sprum. 1955.

Sample 418A-10, CC, (No. 4)

Figures 12, 13 Cicatricosisporites minutaestriatus (Bolkh.) Pocock 1964.

Sample 417D-21-1, 108-110 cm (No. 2)

Figures 14, 15 Cicatricosisporites cf. patapscoensis Brenner 1963.

Sample 417D-17-3, 127-128 cm (No. 10)

Figures 16, 17 Cicatricosisporites subrotundus Brenner 1963.

Sample 418B-29-2, 91-92 cm (No. 10)

Figure 18 Converrucosisporites proxigranulatus Brenner (1963) Sample 417D-21-1, 108-110 cm (No. 1)

Figures 19, 20 Converrucosisporites platyverrucosus Brenner 1963. Sample 418B-34-1, 30-31 cm (No. 3)

Figures 21, 22 Cicatricosisporites venustus Deak 1963. Sample 418B-31-2, 11-13 cm (No. 1)

Figure $23 \quad$ Gleicheniidites circinidites (Cooks.) Dettm. 1963. Sample 418B-34-1, 30-31 cm (No. 3)

Figures 24, 25 Gleicheniidites confossus Hedlund 1966.

Sample 418A-10-1, 95-97 cm (No. 3)

Figures 26-28 Gleicheniidites echinatus (Bolkh.) W.Kr. 1959.

Sample 418B-29-2, 91-92 cm (No. 10)

Figures 29, 30 Costatoperforosporites foveolatus Deak 1962.

Sample 417D-17-1, 94-95 cm (No. 1) 
PLATE 1

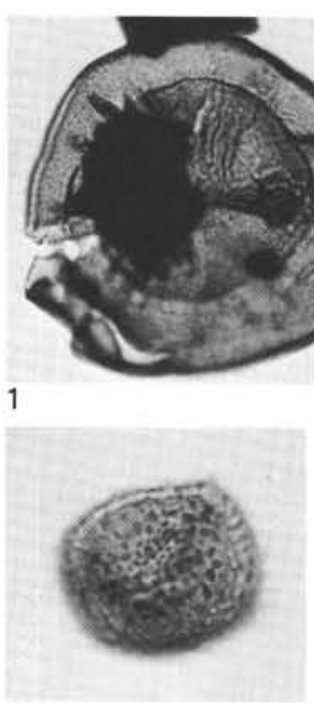

6

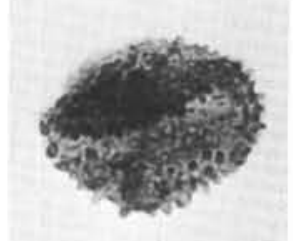

7
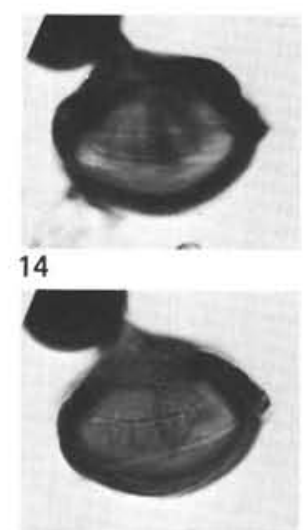

15

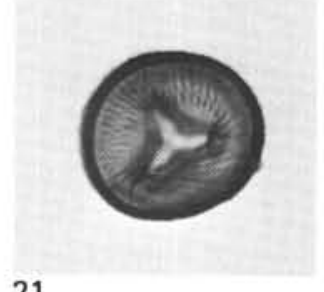

21

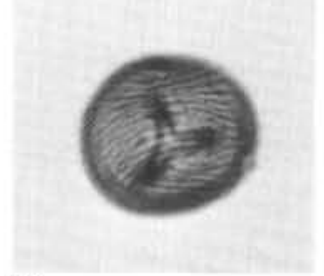

22

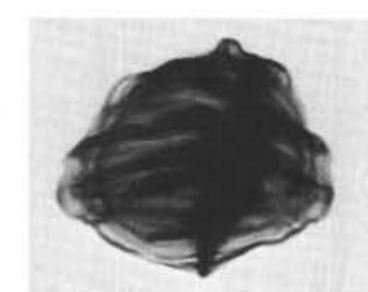

2

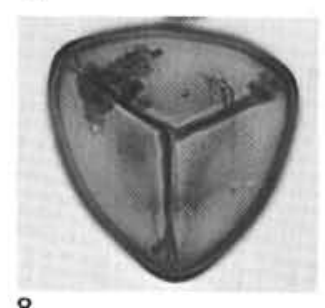

8

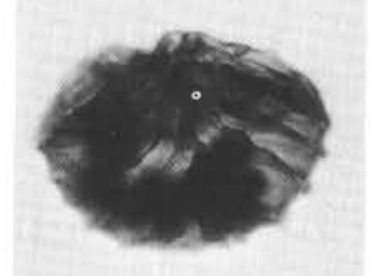

10

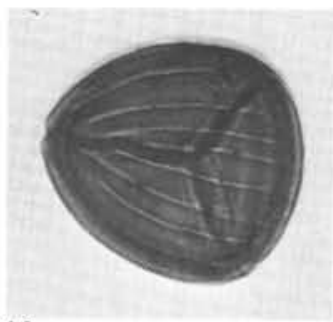

16

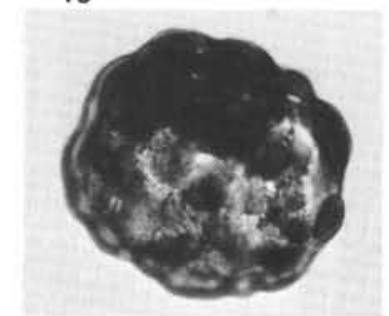

18

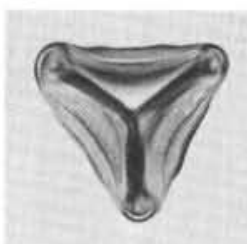

23

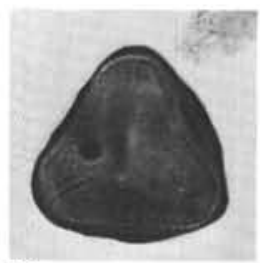

26

24

27

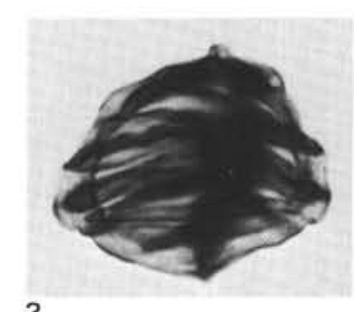

3
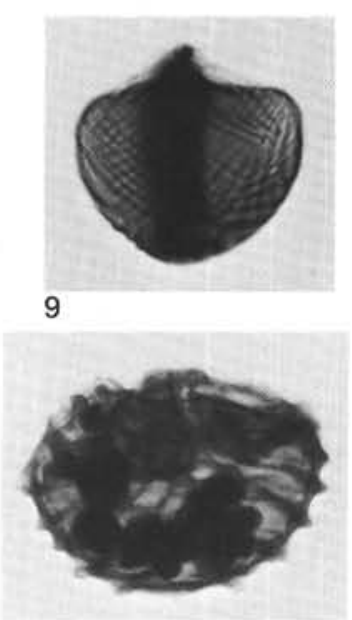

11

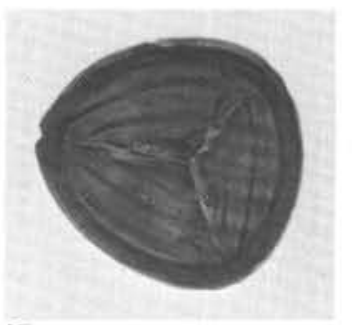

17
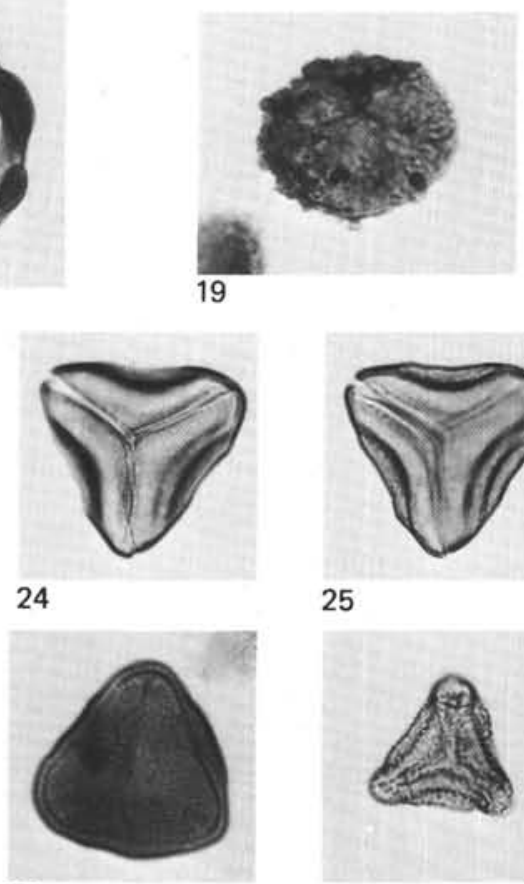

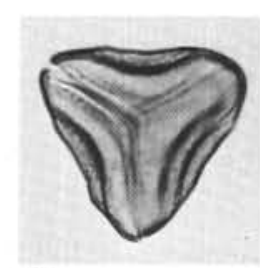

25

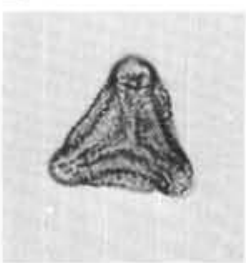

28

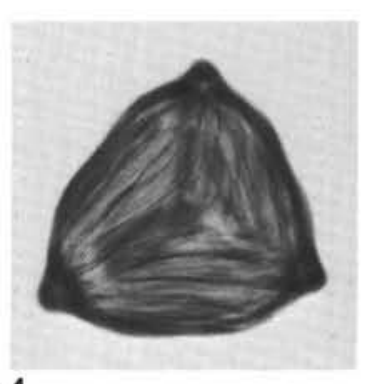

4

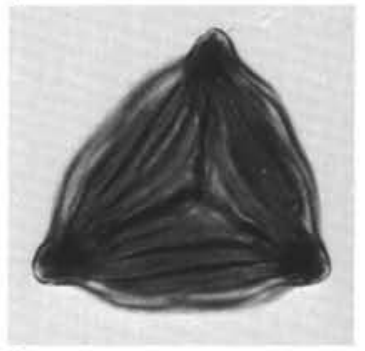

5

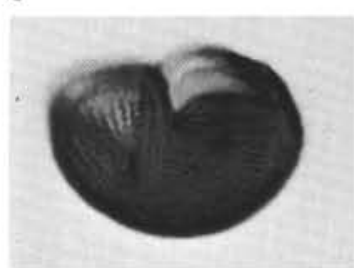

12

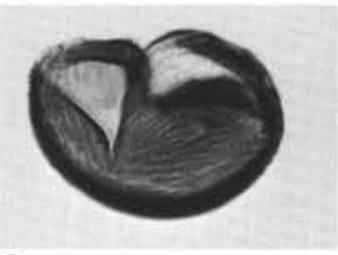

13
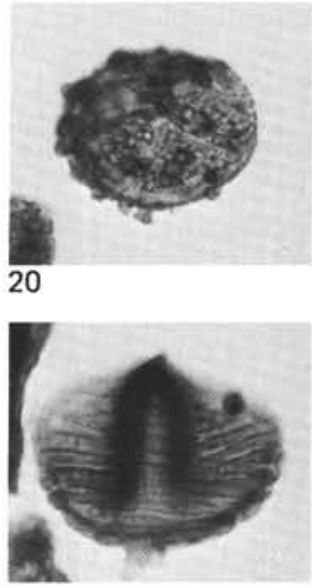

29

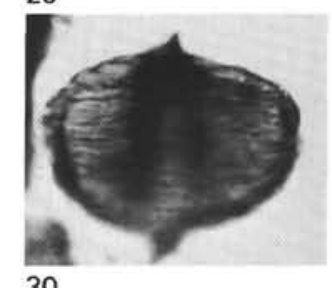


PLATE 2

(All figures $\times 750$ unless otherwise indicated)

Figures 1, 2 Gleicheniidites sp. 1

Sample 418A, 10, CC (No. 9)

Figure $3 \quad$ Klukisporites foveolatus Pocock 1971. Sample 418B-34-1, 30-31 cm (No. 4)

Figures 4,5 Klukisporites areolatus Singh 1971. Sample 417D-21-1, 108-110 cm (No. 1)

Figures 6, $7 \quad$ Psilatriletes circumundulatus Brenner 1963. Sample 417D, 17, CC (No. 5)

Figure $8 \quad$ Triplanosporites sp. 2. Sample 417D, 17, CC (No. 9)

Figures 9, 10 Concavisporites juriensis Balme 1957. Sample 418B-34-1, 30-31 cm (No. 3)

Figures 11-13 Stereisporites antiquasporites (Wils. \& Webst.) Dettm. 1963.

Sample 418B-31-2, 11-13 cm (Nos. 4 and 1)

Figures 14, 15 Undulatisporites undulapolus Brenner 1963. Sample 418B-34-1, 30-31 cm (No. 2)

Figures 16, 17 Undulatisporites cf. fossulatus Singh 1971. Sample 417D-17-3, 127-128 cm (No. 10)

Figures 18, 19 Triplanosporites sp. 1. Sample 418B-31-2, 11-13 cm (No. 2)

Figures 20, 21 Trilete sp. 1.

Sample 418B-31-2, 11-13 cm (No. 3)

Figures 22, 23 Trilete sp. 2.

Sample 417D-21-1, 108-110 cm (No. 2)

Figures 24, 25 Alisporites thomasi Couper 1958. Sample 418B-34-1, 30-31 cm (No. 3)

Figures 26-28 Vitreisporites pallidus (Reiss.) Nilss. 1958. Sample 418B-31-2, 11-13 cm (No. 1)

Figure 29 Parvisaccites rugulatus Brenner 1963. Sample 417D, 17cc (No. 7)

Figure $30 \quad$ Rugubivesiculites minimus Burger 1966. Sample 418A-10-1, 95-97 cm (No. 3)

Figures 31, 32 Parvisaccites radiatus Couper 1958. Sample 417D-17-1, 94-95 cm (No. 1) 
PLATE 2
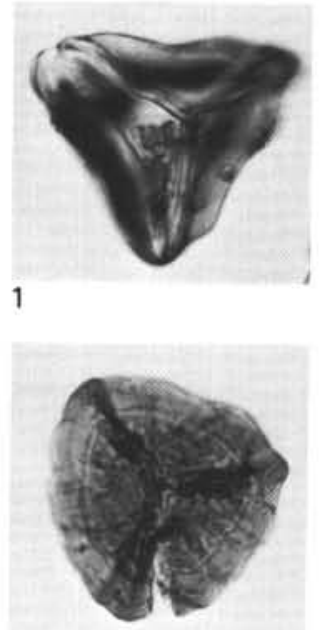

6

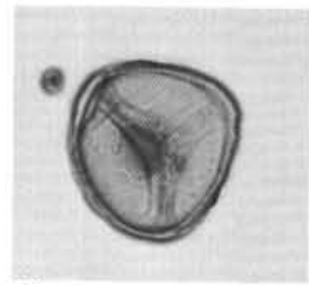

11

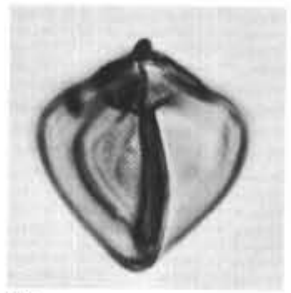

18
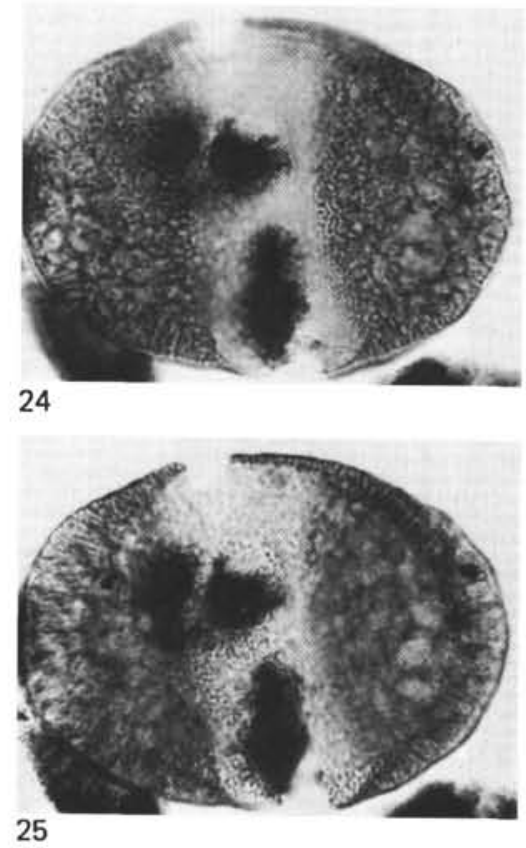

7

12

19
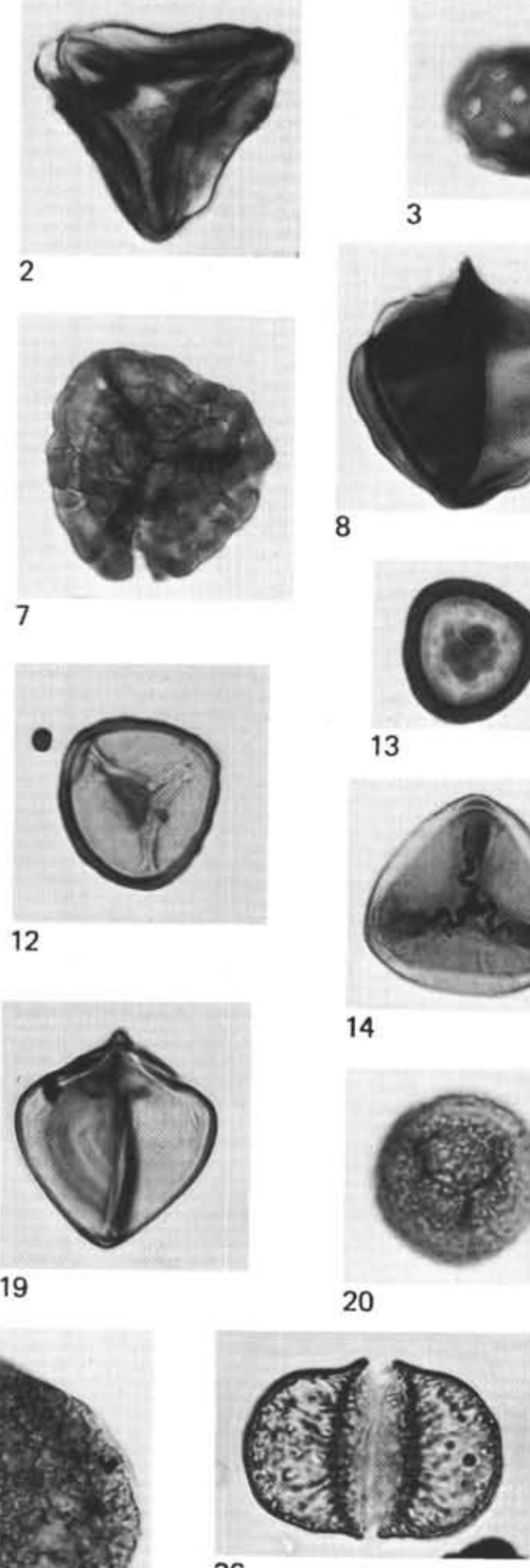

26
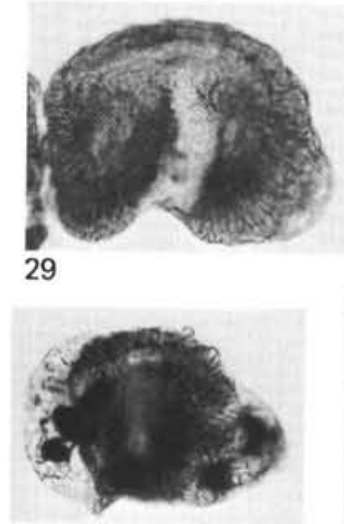

30

20
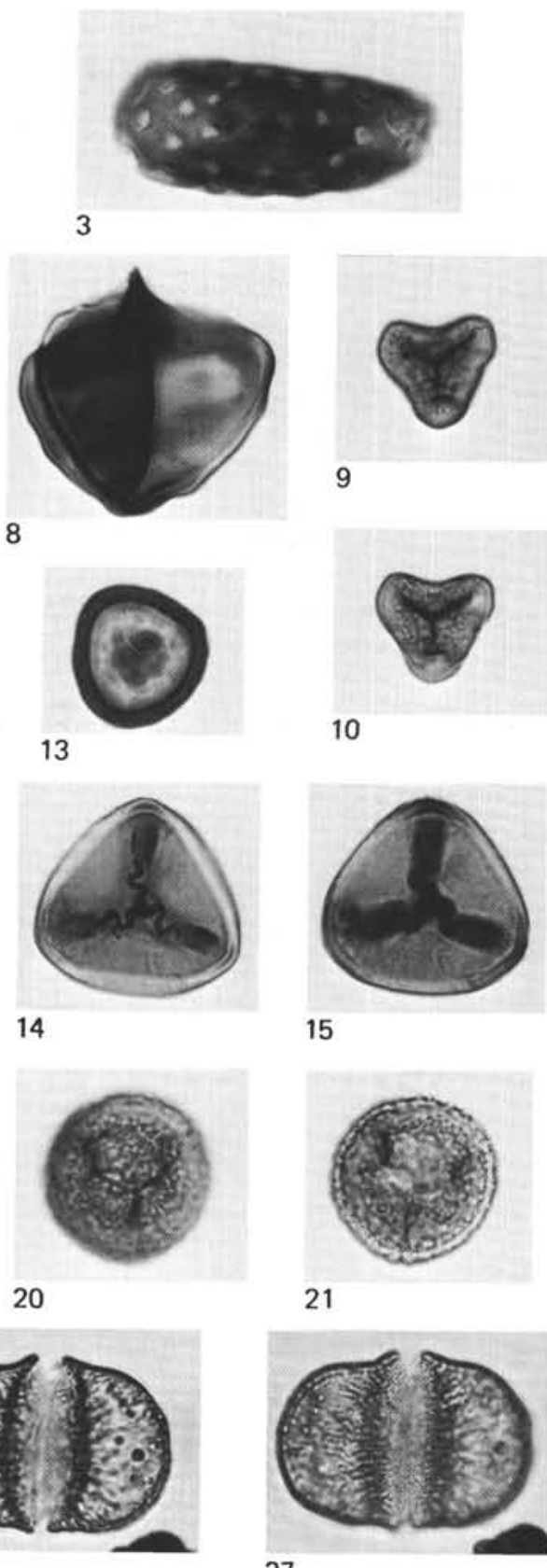

27

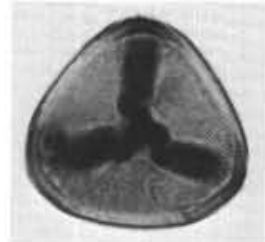

15
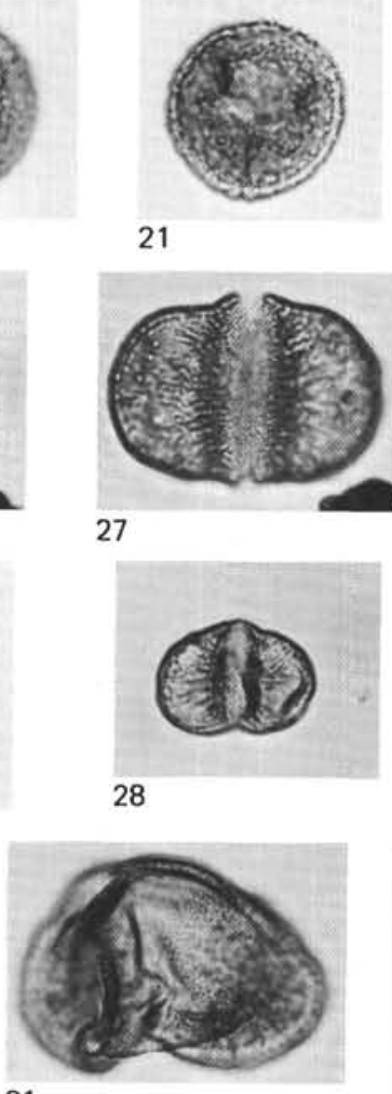

31

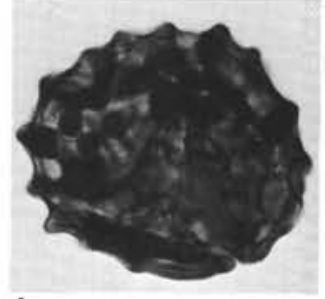

4

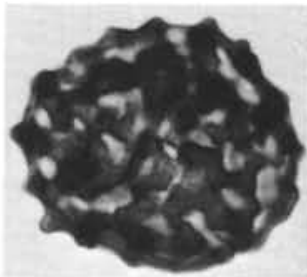

5
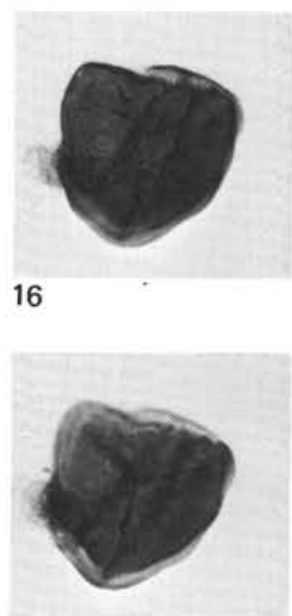

17

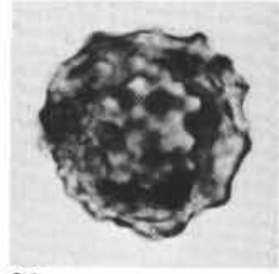

22

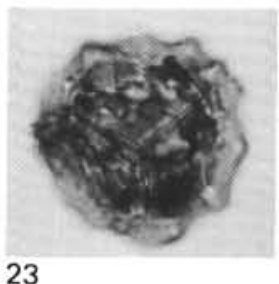

23

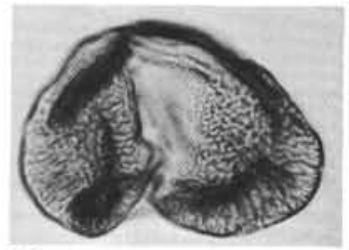


PLATE 3

(All figures $\times 750$ unless otherwise indicated)

Figures 1, 2 Podocarpidites multesimus (Bolkh.) Pocock 1962.

Sample 418A, 10, CC (No. 8)

Figures 3-5 Cedripites admirabilis (Bolkh.) W.Kr. 1971.

Sample 418B-31-2, 11-13 cm (No. 1)

Figures 6-9 Classopollis noeli Reyre 1970.

Sample 417D-17-3, 65-66 cm (No. 1)

Sample 417D-21-1, 108-110 cm (No. 3)

Figures 10, 11 Classopollis brasiliensis Herngreen 1975.

Sample 417D-17-1, 94-95 cm (No. 3)

Figures 12, 13 Exesipollenites tumulus Balme 1957.

Sample 418B-31-2, 11-13 cm (No. 1)

Sample 417D-21-1, 108-110 cm (No. 1)

Figure $14 \quad$ Exesipollenites sp. 1

Sample 418B-31-2, 11-13 cm (No. 4)

Figure $15 \quad$ Cycadopites minimus (Cooks. 1947).

Sample 418B-34-1, 30-31 cm (No. 2)

Figure 16 Cycadopites carpentieri (Delc. \& Sprum. 1955).

Sample 418B-34-1, 30-31 cm (No. 4)

Figure 17 Callialasporites damperi (Balme) Sukh Dev 1961.

Sample 418B-28-2, 53-55 cm (No. 1)

Figures 18, 19 Classopollis spinosus Herngreen 1973.

Sample 418B-28-2, 53-55 cm (No. 1)

Figure $20 \quad$ Cerebropollenites mesozoicus (Couper) Nilsson 1958.

Sample 417D-19-2, 11-14 cm (No. 9)

Figures 21, 22 Araucariacites cf. hungaricus Deak 1965.

Sample 417D-19-2, 6-8 cm (No. 8)

Figure 23 Eucommidites ? glottus (Brenner 1963).

Sample 418B-31-2, 11-13 cm (No. 3)

Figures 24, 25 Cycadopites sp. 1

Sample 417D-17-1, 94-95 cm (No. 3)

Figure $26 \quad$ Inaperturopollenites hiatus (R.Pot.) Th. \& Pf. 1953.

Sample 418A-10-1, 95-97 cm (No. 3)

Figures 27, 28 Eucommidites sp. 1

Sample 417D-21-4, 22-24 cm (No. 3)

Figures 29, 30 Scidopityspollenites (sp. 1)

Sample 418B-31-2, 11-13 cm (No. 3)

Figures 31, 32 Eucommidites troedssonii (Erdtm.) R.Pot. 1958.

Sample 418B-31-2, 11-13 cm (No. 2)

Figure 33 Araucariacites australis Cooks. 1947.

Sample 417D-21-1, 108-110 (No. 1) 


\section{PLATE 3}
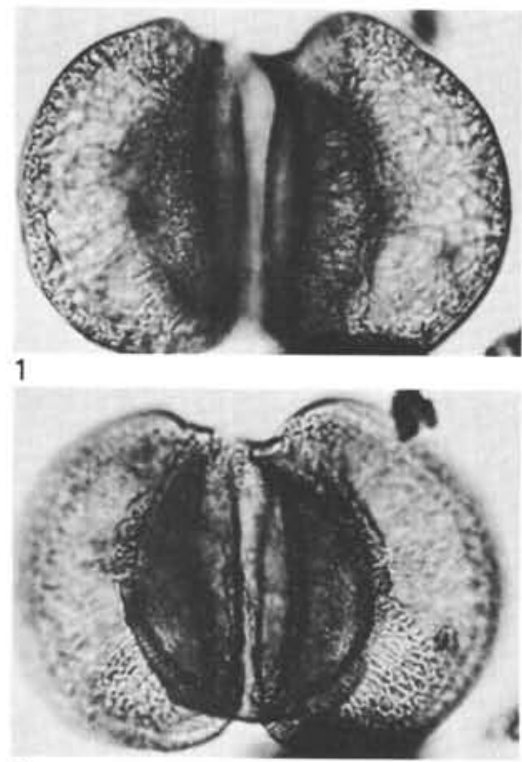

2

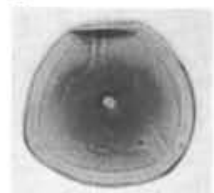

14

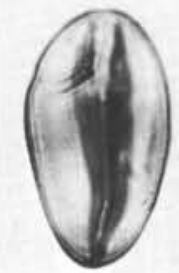

15

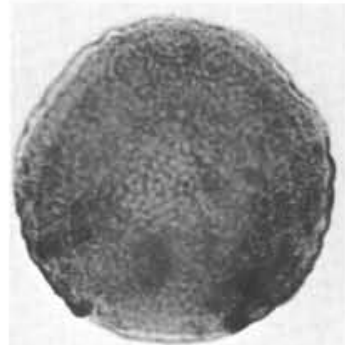

21

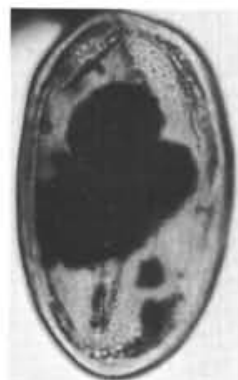

27

22

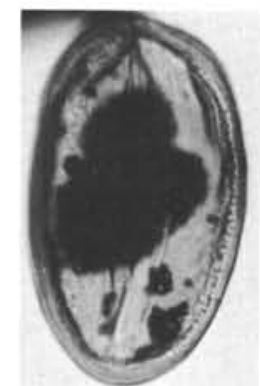

28

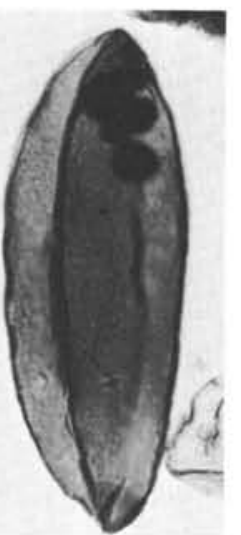

16

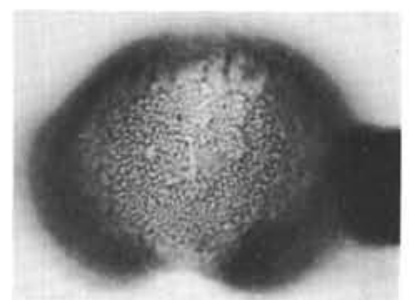

3

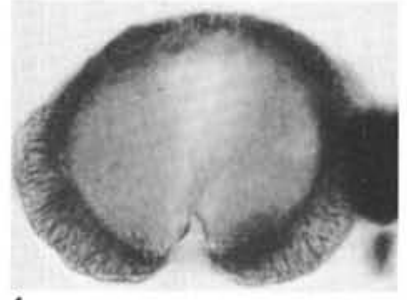

4

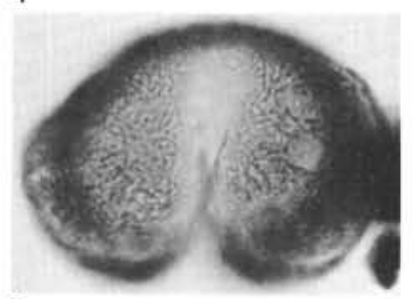

5

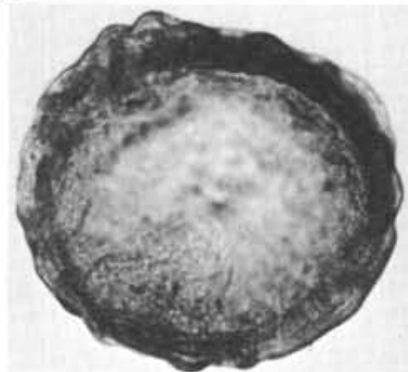

17

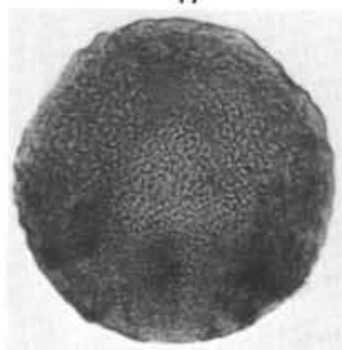

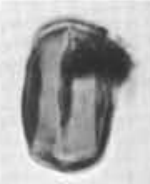

23
24

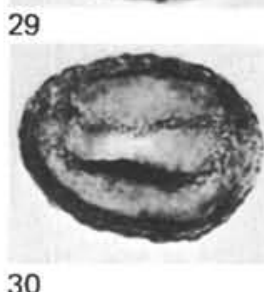

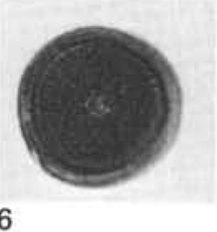

6

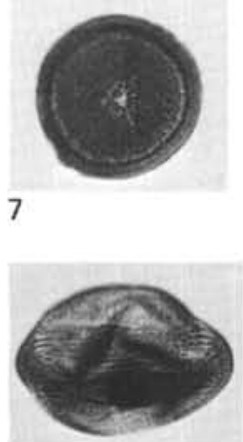

8

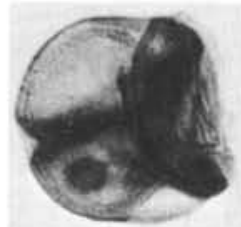

9

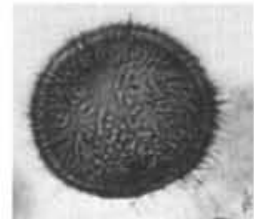

18

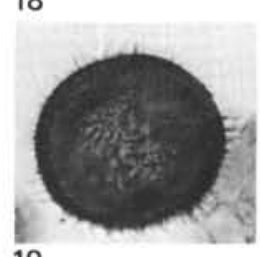

19

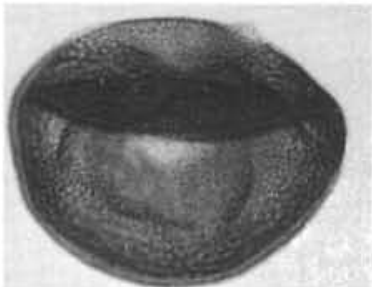

10

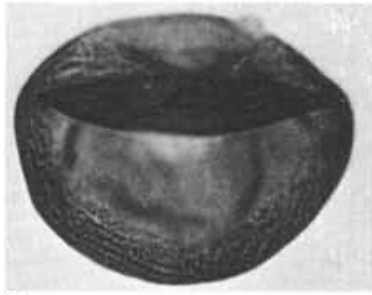

11
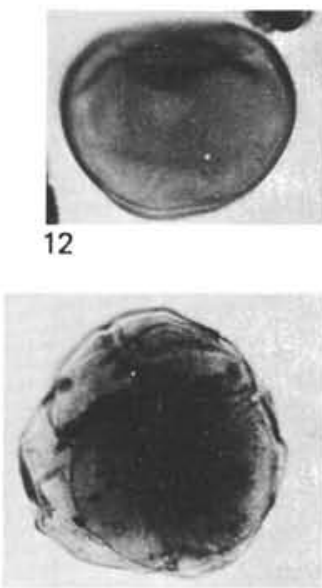

13

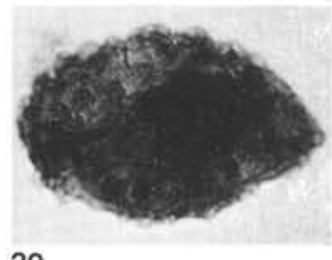

20
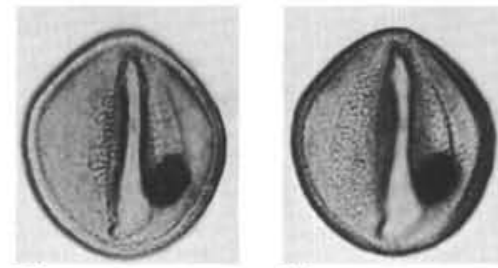

25

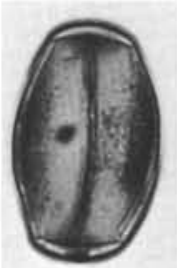

31

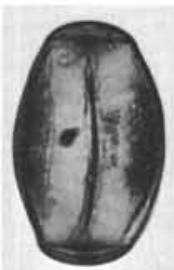

32

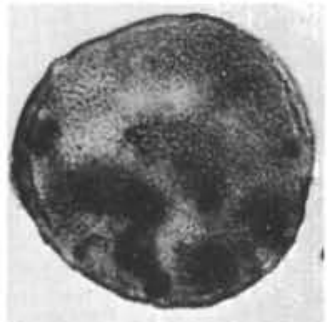

33
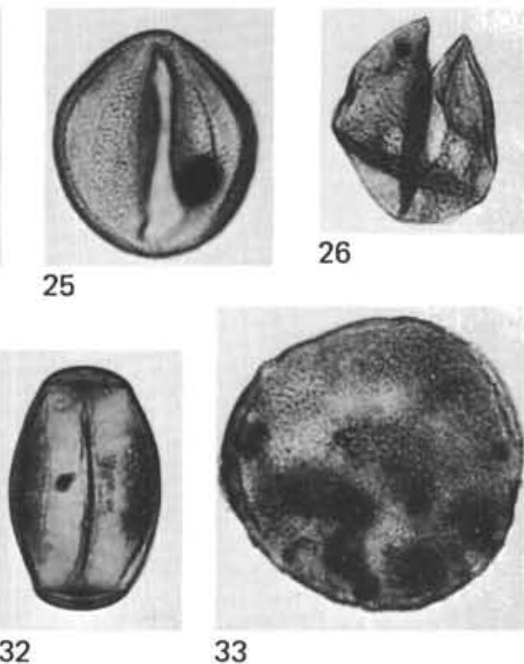
PLATE 4

(All figures $\times 750$ unless otherwise indicated)

Figure $1 \quad$ Aumancisporites cf. cretaceous (Pocock) Pocock 1964 Sample 418A-10-1, 95-97 cm (No. 3)

Figure $2 \quad$ Ephedripites (Distachyapites) multistriatus (Pocock 1964) Sample 418B-34-1, 30-31 cm (No. 3)

Figure 3 Ephedripites (Distachyapites) sp. 5- Herngreen (1973) Sample 418B-31-2, 11-13 cm (No. 4)

Figures 4, $5 \quad$ Ephedripites (Distachyapites) cf. markovii (Pocock 1964) Sample 418B-34-1, 30-31 cm (No. 3)

Figures 6, 7 Ephedripites (Spiralipites) barghoornii (Pocock 1964)

Sample 418A-10-1, 95-97 cm (No. 3)

Figures 8, 9 Ephedripites (Distachyapites) sp. 2 - Herngreen (1973) Sample 418B-31-2, 11-13 cm (No. 2)

Figures 10, 11 Ephedripites (Spiralipites) staplinii (Pocock 1964) Sample 418B-34-1, 30-31 cm (No. 3)

Figure 12 Ephedripites (Spiralipites) jansonii (Pocock) Muller 1968 Sample 417D, 17, CC (No. 3)

Figure 13 Ephedripites (Distachyapites) sp. 4 - Herngreen (1973) Sample 418A-10-1, 95-97 cm (No. 4)

Figures 14, 15 Ephedripites (Distachyapites) cf. mediolobatus Bolkh. 1953 Sample 418B-31-2, 11-13 cm (No. 3)

Figure $16 \quad$ Steevesipollenites $\mathrm{cf}$. binodosus Stover 1964 Sample 418B-34-1, 30-31 cm (No. 4)

Figure $17 \quad$ Steevesipollenites sp. 1 Sample 418B-28-2, 53-55 cm (No. 1)

Figures 18-21 Steevesipollenites multilineatus Stover 1964 Sample 418B-34-1, 30-31 cm (No. 2)/Sample 417D-19-2, 11-14 cm (No. 10)

Figures 22, 23 Steevesipollenites $\mathrm{cf}$. binodosus Stover 1964 Sample 418B-31-2, 4-6 cm (No. 7)

Figures 24-27 Welwitschiapites sp. 1 Sample 417D-19-2, 6-8 cm (No. 8) / Sample 418B-31-2, 11$13 \mathrm{~cm}$ (No. 4)

Figure $28 \quad$ Steevesipollenites sp. 2 Sample 418B-34-1, 30-31 cm (No. 4)

Figures 29, 30 Steevesipollenites binodosus Stover 1964 Sample 417D, 17, CC (No. 9) 
PLATE 4

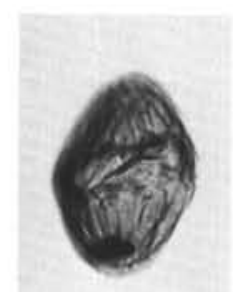

1

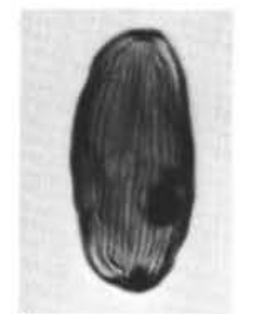

8

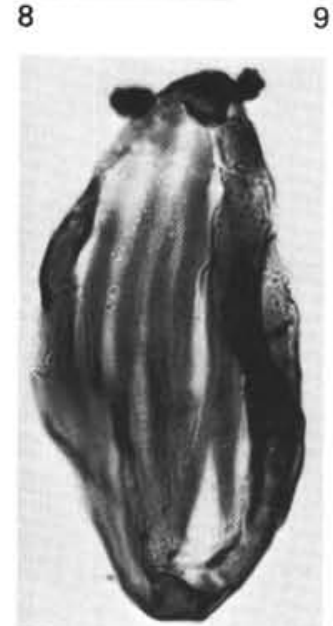

13

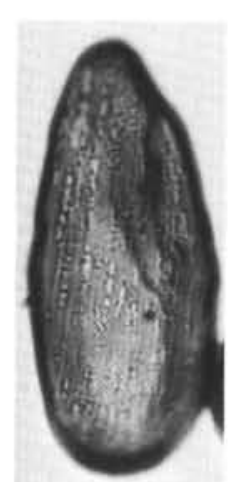

18

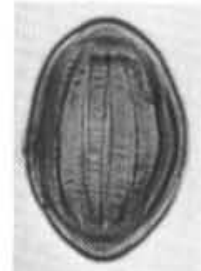

24

2

9

19

25
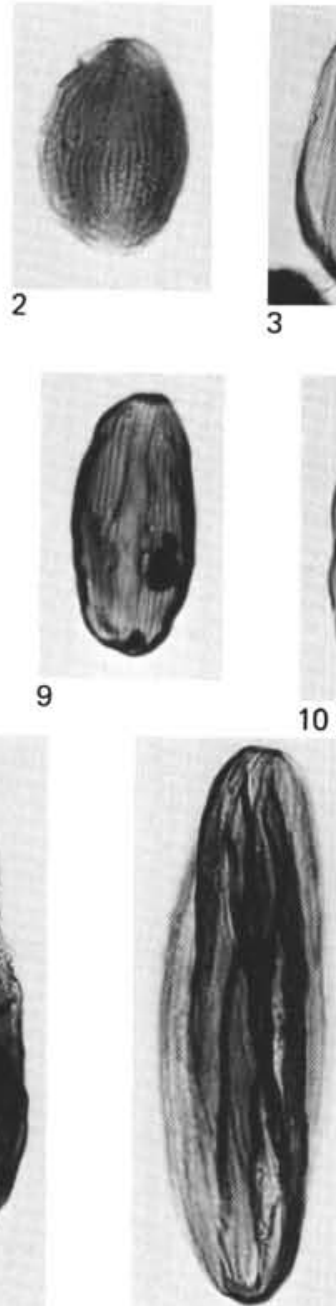

14
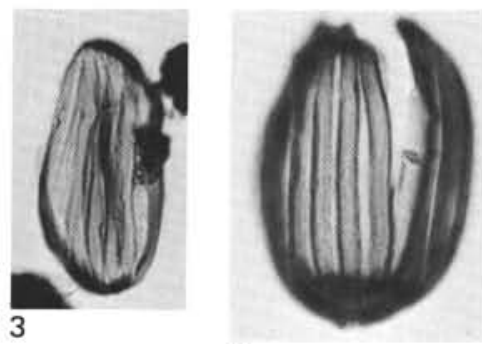

4
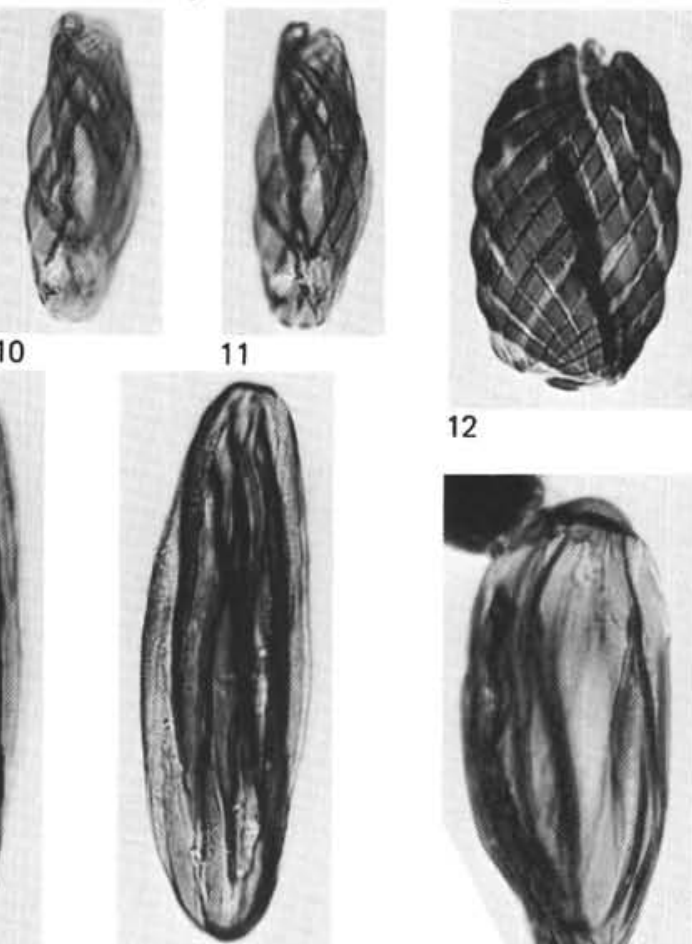

15
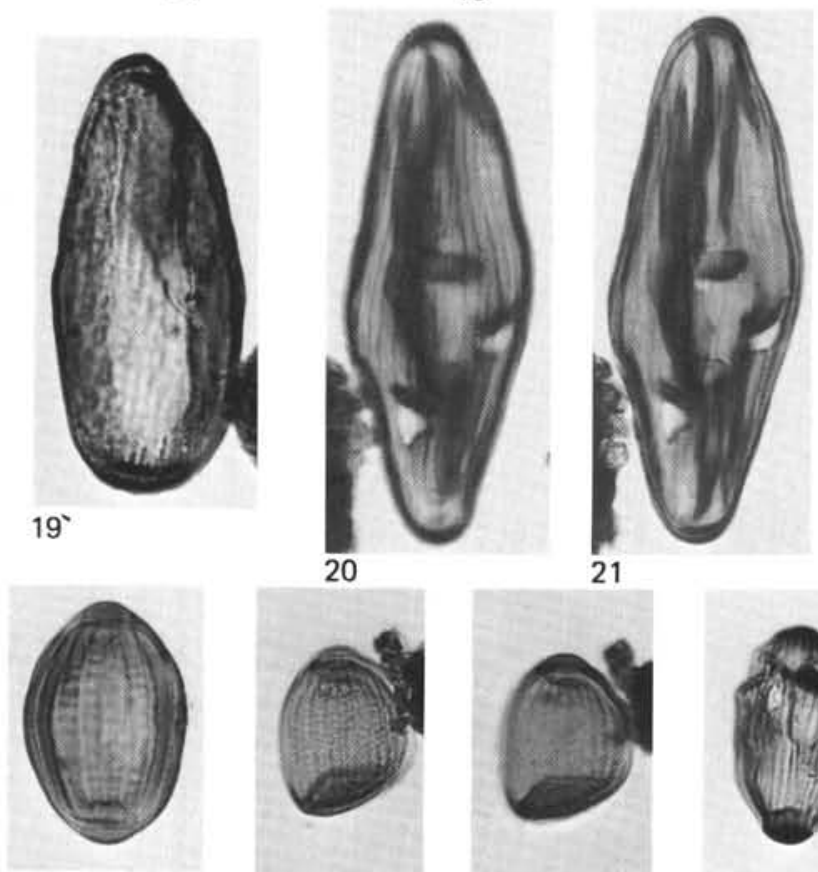

26

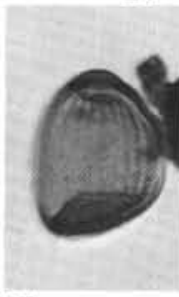

27

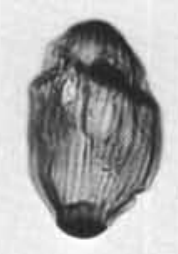

28

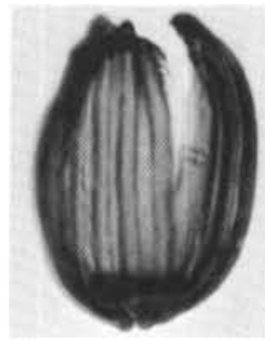

5
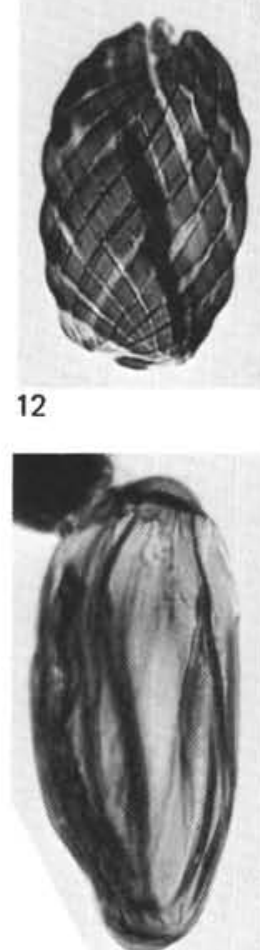

16

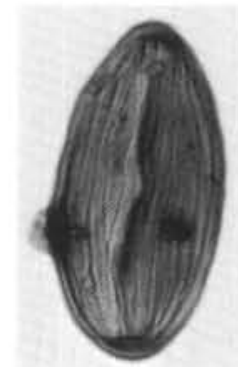

22

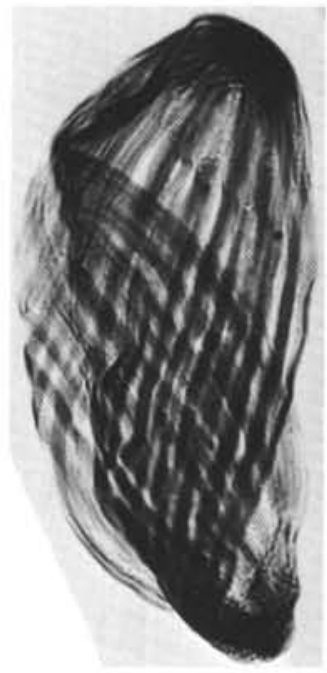

17

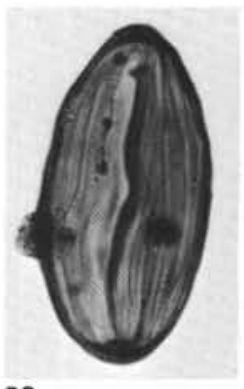

23

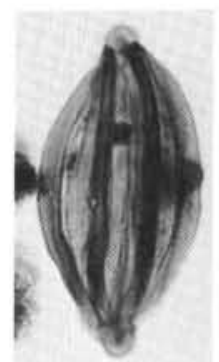

29

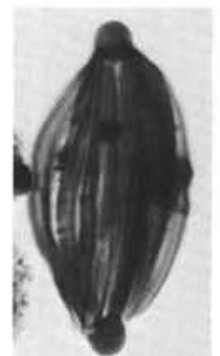

30 


\section{PLATE 5}

(All figures $\times 750$ unless otherwise indicated)

Figures 1, 2 Elaterosporites klaszi (Jard. \& Magl.) Jard. 1967

Sample 417D-17-1, 94-95 cm (No. 1)

Figures 3-5 Arecipites sp. 1

(Figure 4: $\times 1500$ )

Sample 418-31-2, 11-13 cm (No. 1)

Figures 6, $7 \quad$ Arecipites sp. 2

(Figure 7: $\times 1500$ )

Sample 418B-31-2, 11-13 cm (No. 1)

Figures 8, 9 Monocolpopollenites cf. tranquillus tranquillus ( $\mathrm{R}$.

Pot.) Th. \& Pf. 1958

(Figure 9: $\times 1500$ )

Sample 418A, 10 cc (No. 9)

Figures 10-12 Clavatipollenites hughesii Couper 1958

(Figure 12: $\times 1500$ )

Sample 418B-31-2, 11-13 cm (No. 3)

Figures 13, 14 Magnolipollis sp. 1

(Figure 14: $\times 1500$ )

Sample 418B-31-2, 11-13 cm (No. 2)

Figures 15, 16 Clavatipollenites tenellis Phillips \& Felix 1971

Sample 418B-34-1, 30-31 cm (No. 3)

Figures 17, 18 Monocolpopollenites cf. tranquillus verrucatus W.

Kr. 1962a

(Figure 18: $\times 1500$ )

Sample 418B-31-2, 11-13 cm (No. 2)

Figures 19, 20 Clavatipollenites hughesii Couper 1958

Sample 418B-31-2, 11-13 cm (No. 1)

Figures 21, 22 Milfordia sp. 1

(Figure 22: $\times 1500$ )

Sample 418B-31-2, 11-13 cm (No. 2)

Figures 23, 24 Monocolpate sp. B

(Figure 24: $\times 1500$ )

Sample 418B-31-2, 11-13 cm (No. 1)

Figures 25-27 Monocolpate sp. A

(Figure 27: $\times 1500$ )

Sample 418B-34-1, 30-31 cm (No. 4)

Figures 28-31 "Trichotomosulcites" Erdtm. 1945 sp. 1

(Figure 31: $\times 1500$ )

Sample 418B-31-2, 11-13 cm (No. 1)

Figures 32-34 Retimonocolpites dividuus Pierce 1961

(Figures 33, 34: $\times 1500$ )

Sample 418B-31-2, 11-13 cm (No. 2)

Figures 35-37 "Trichotomosulcites' sp. 2

(Figure 37: $\times 1500$ )

Sample 418B-34-1, 30-31 cm (No. 3) 
PLATE 5
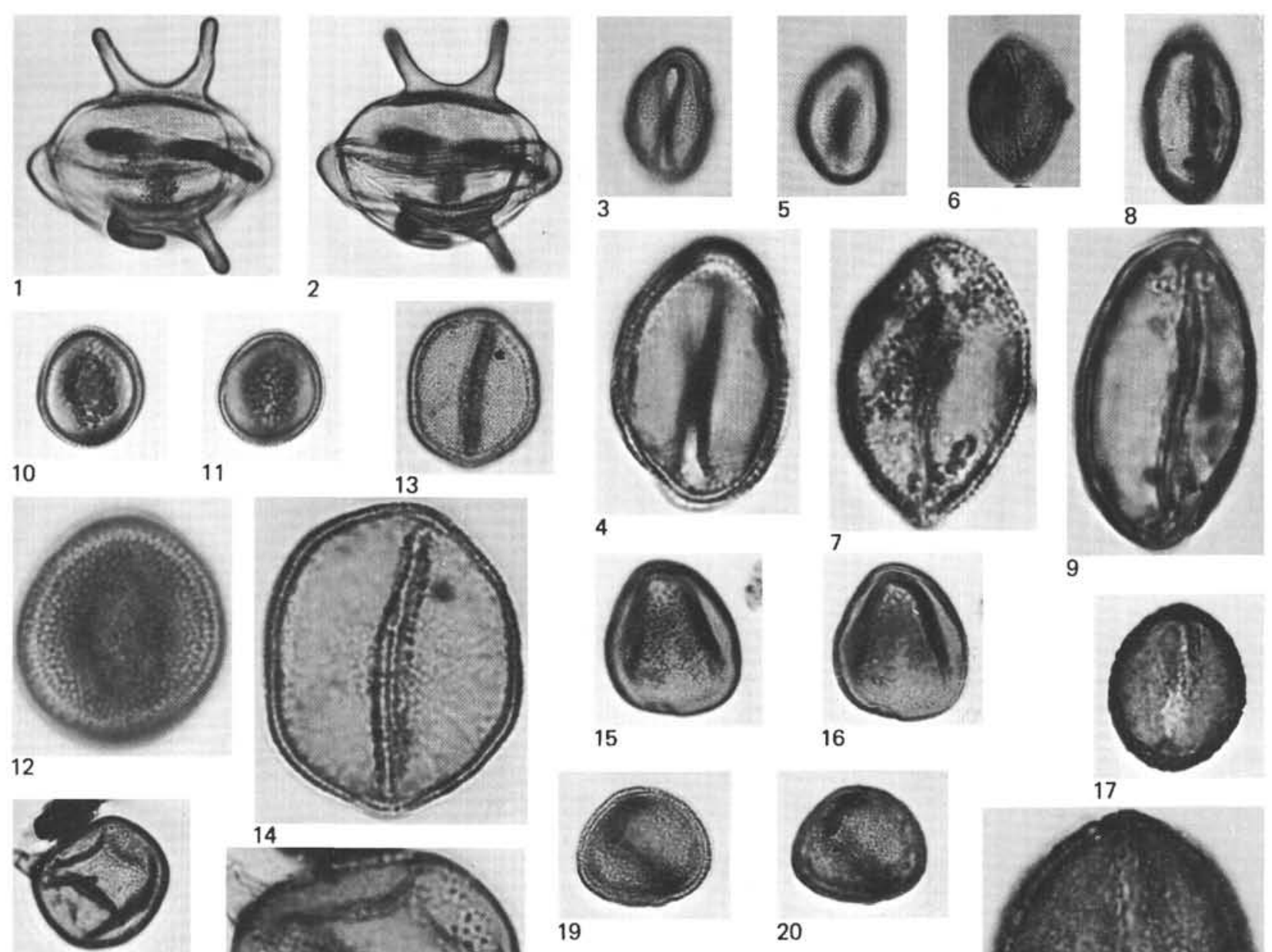

21
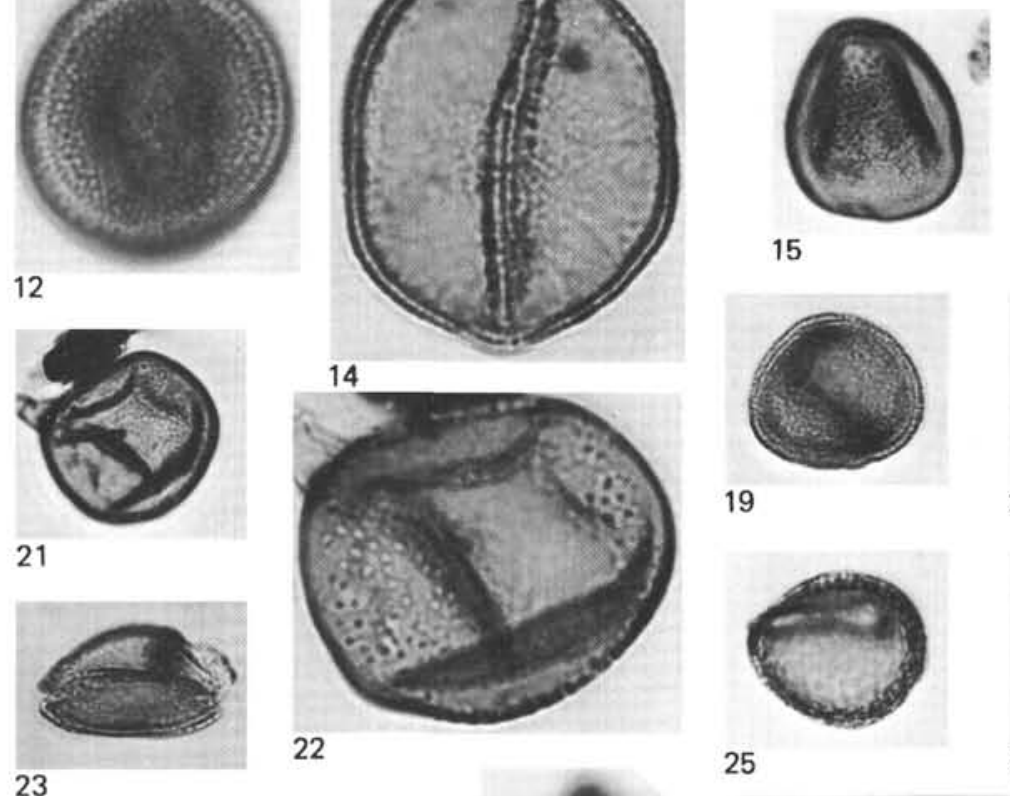

15

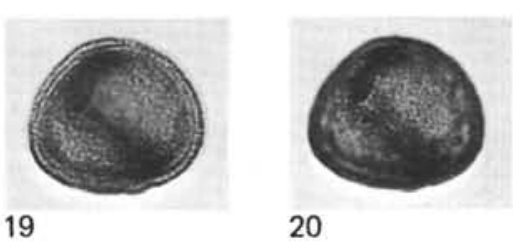

19

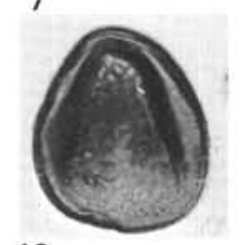

9
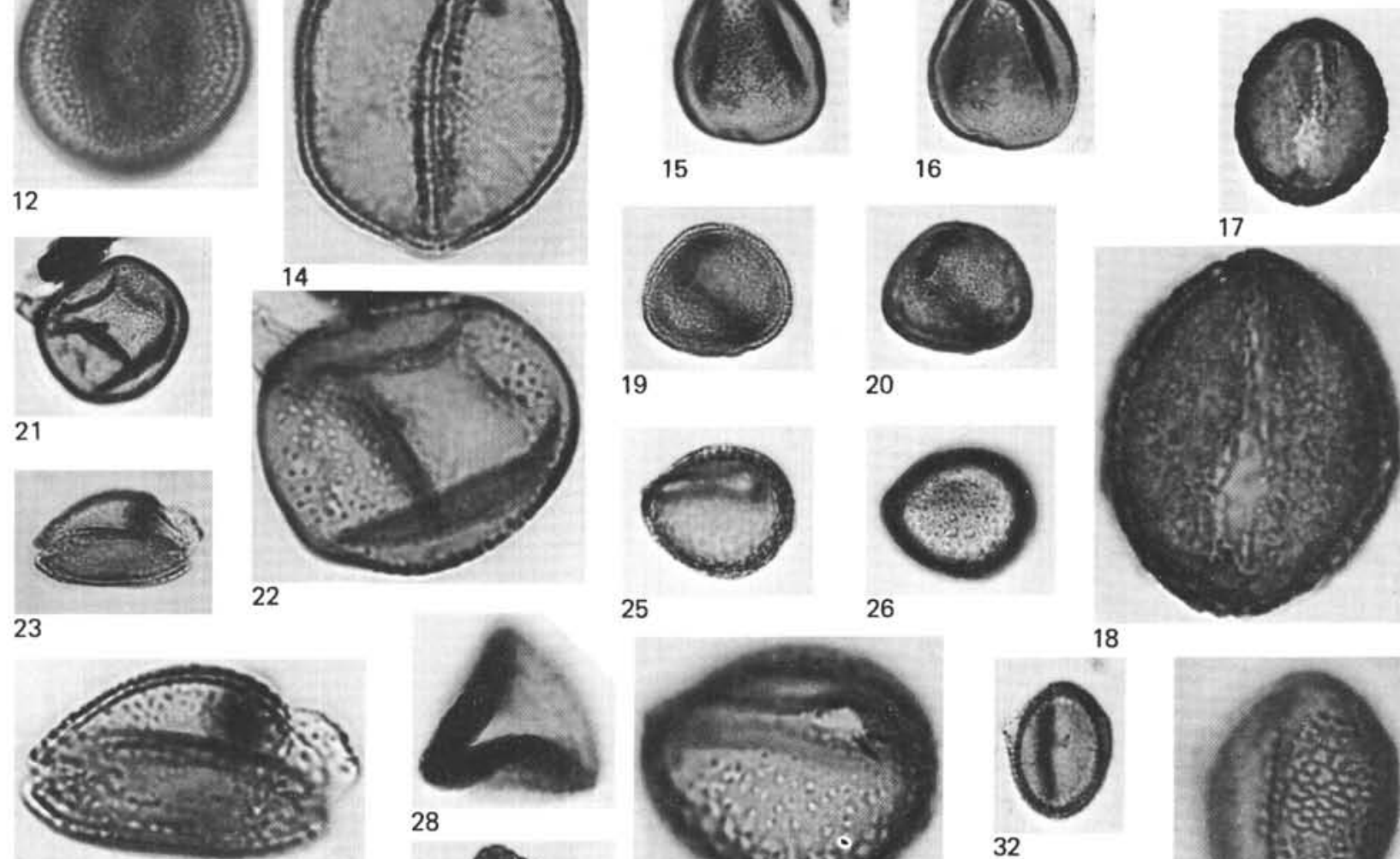

24
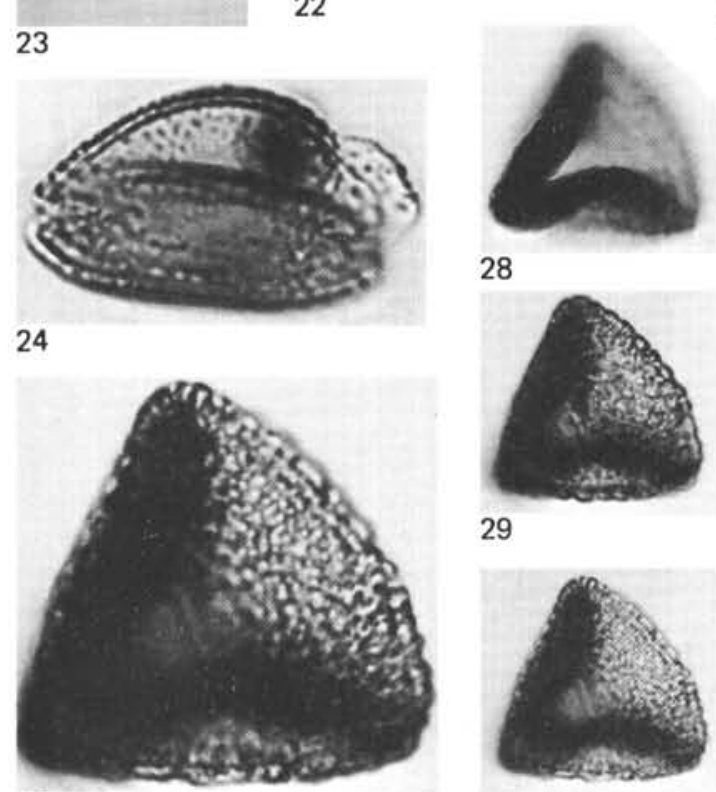

30
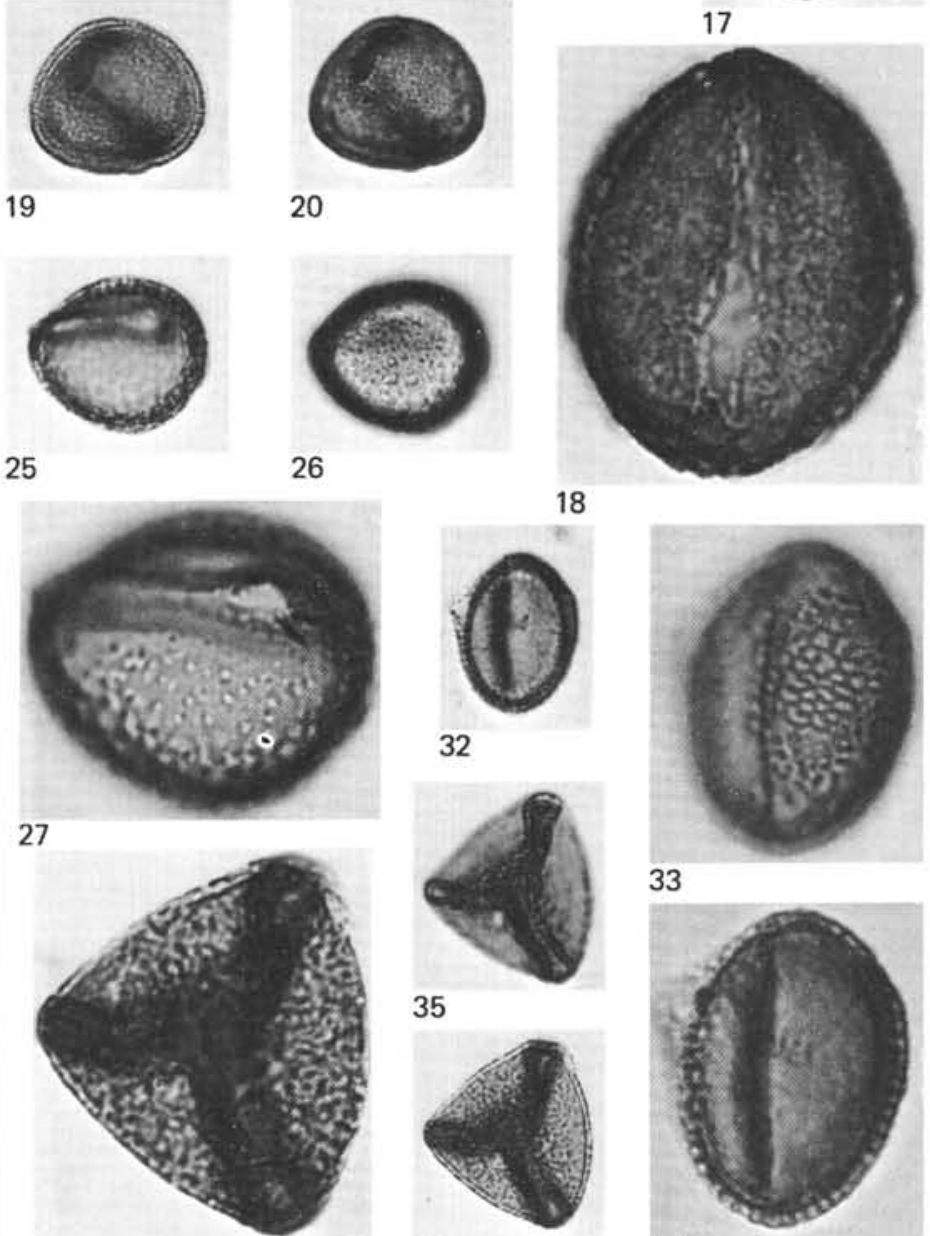

37

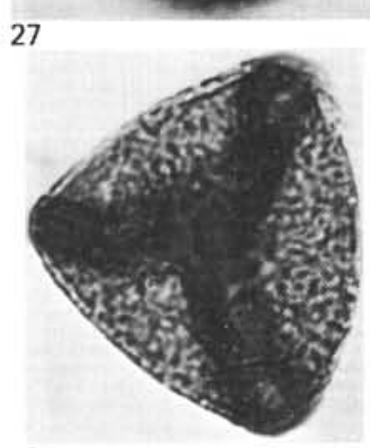

36

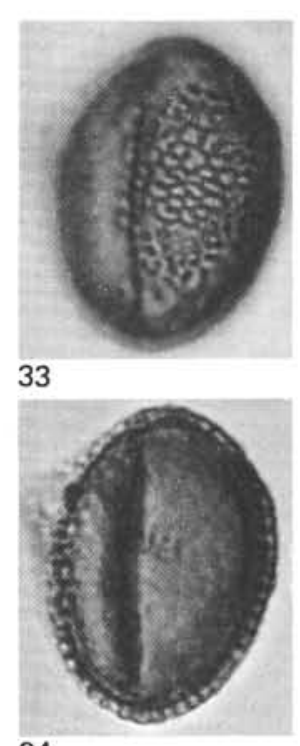




\section{PLATE 6}

(All figures $\times 750$ unless 'otherwise indicated)

Figures 1-3 Retimonocolpites dividuus Pierce 1961

(Figure 3: $\times 1500$ )

Sample 418B-28-2, 53-55 cm (No. 1)

Figures 4-8 Retimonocolpites clavatus (Singh 1971)

Sample 418B-34-1, 30-31 cm (No. 4)

Figures 9-11 Retimonocolpites echinatus n. sp.

(Figure 9: $\times 1500$ )

Sample 418B-31-2, 4-6 cm (No. 7)

Figures 12, 13 Retimonocolpites $\mathrm{cf}$. peroreticulatus (Brenner) Doyle 1975

Sample 418B-31-2, 11-13 cm (No. 1)

Figures 14, 15 Retimonocolpites peroreticulatus (Brenner) Doyle 1975

(Figure 14: $\times 1500$ )

Sample 418B-34-1, 30-31 cm (No. 2)

Figures 16-20 Retimonocolpites reticulatus (Brenner 1963)

(Figure 18: $\times 1500$ )

Sample 418B-31-2, 11-13 cm (No. 4)

Figures 21-24 Tricolpites crassimurus (Groot \& Penny) Singh 1971

Sample 418B-31-2, 11-13 cm (No. 3)

Sample 418B-31-2, 11-13 cm (No. 1)

Figures 25, 26 Tricolpites cf. parvulus (Groot \& Penny 1960)

Sample 418B-34-1, 30-31 cm (No. 3)

Figures 27-29 Striatopollis dubius (Jard. \& Magl.) Morgan 1978

Sample 417D-17-3, 65-66 cm (No. 2)

Figures 30, 31 Tricolpites cf. barrandei Paclt. 1971

Sample 417D, 17, CC (No. 6)

Figures 32, 33 Tricolpites albiensis Kemp 1968

Sample 418B-31-2, 11-13 cm (No. 1)

Figures 34, 35 Tricolpites parvulus (Groot \& Penny 1960)

Sample 418B-31-2, 11-13 cm (No. 4)

Figures 36, 37 Tricolpites sp. 1

Sample 418B-31-2, 11-13 cm (No. 1)

Figures 38, 39 Tricolpites němejci Paclt. 1971

Sample 417D, 17, CC (No. 7)

Figures 40, 41 'Tricolpopollenites' macroreticulatus Groot \& Groot 1962 Sample 417D, 17, CC (No. 10)

Figures 42-44 “Tricolpopollenites" pumilis Groot, Penny \& Groot 1961 Sample 418B-31-2, 11-13 cm (Nos. 1 and 3)

Figures 45, 46 Tricolpites sagax Norris 1967

(Figure 45: $\times 1500$ )

Sample 418B-31-2, 11-13 cm (No. 3) 
PLATE 6
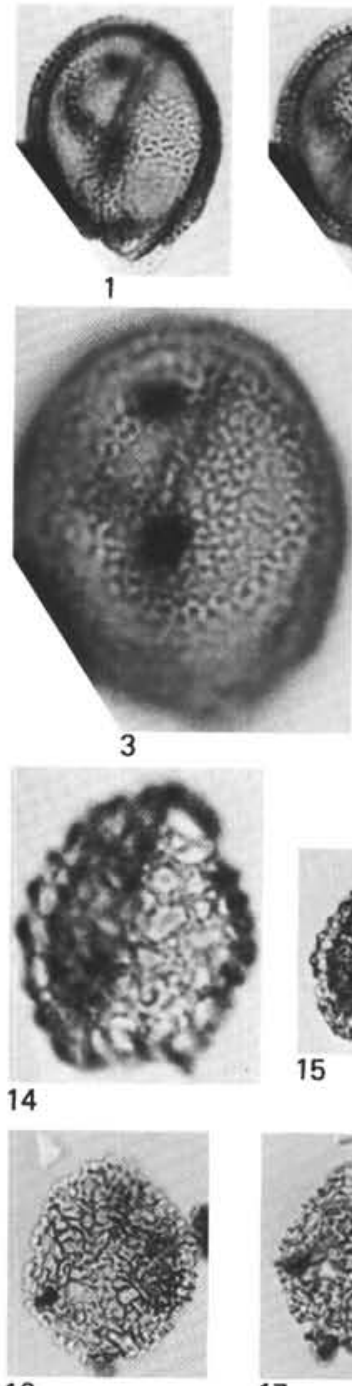

16

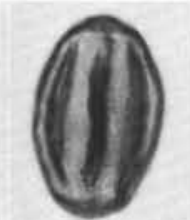

25

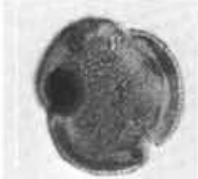

3

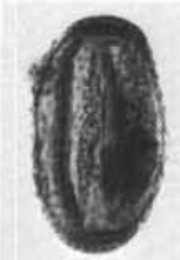

40

17

26

3

41
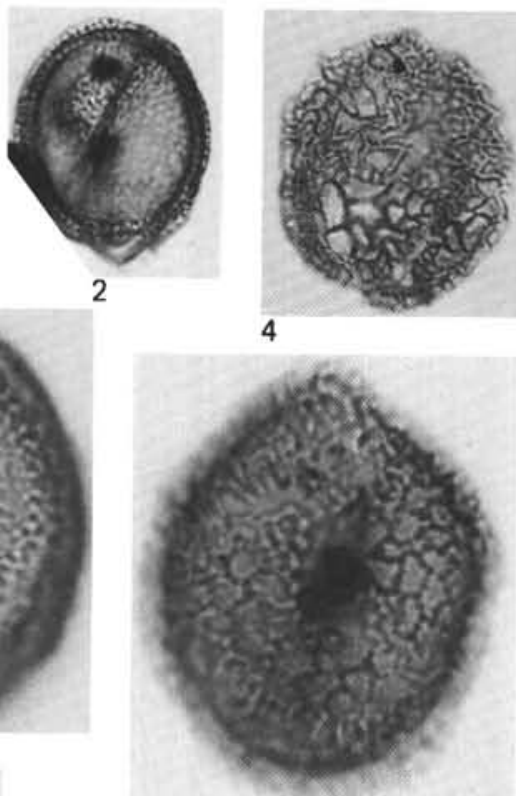

9
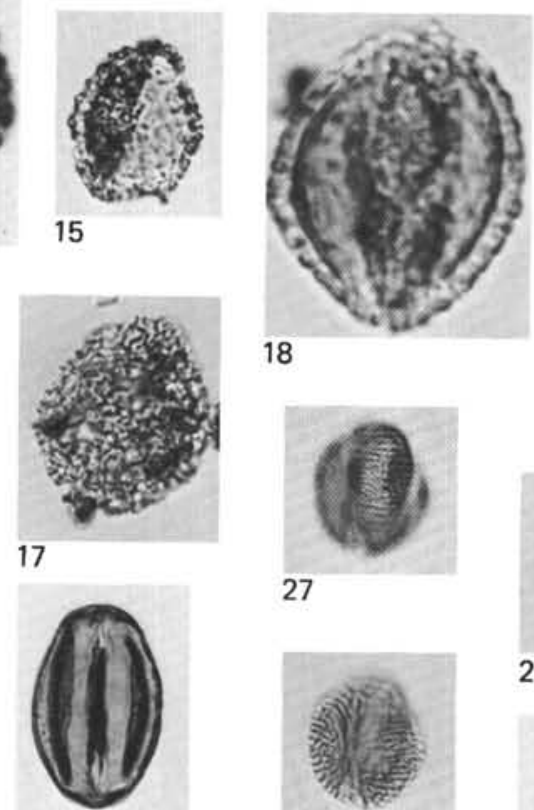

18
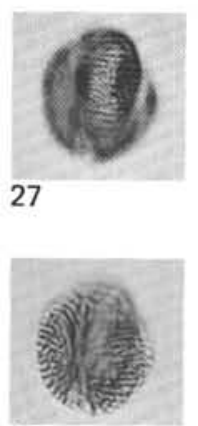

28
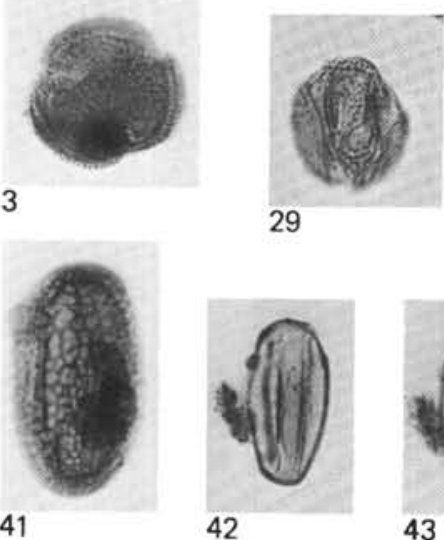

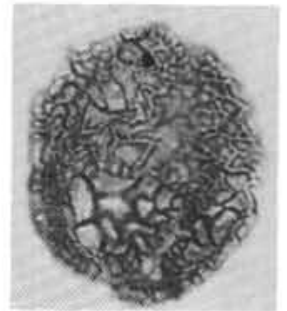

\section{5}
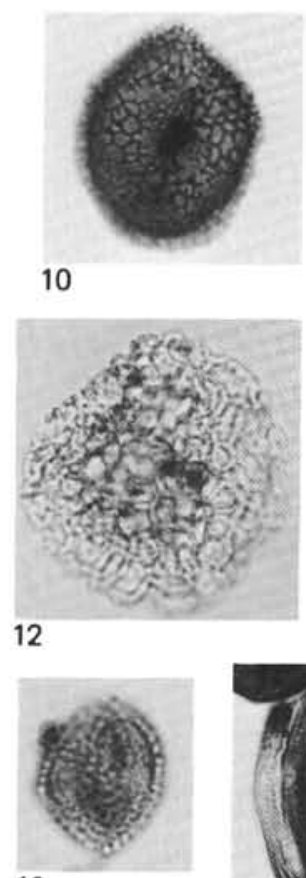

19

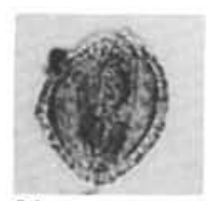

20

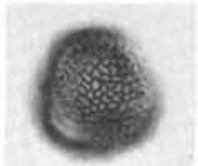

30

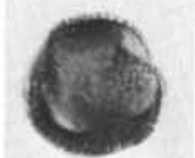

31

34
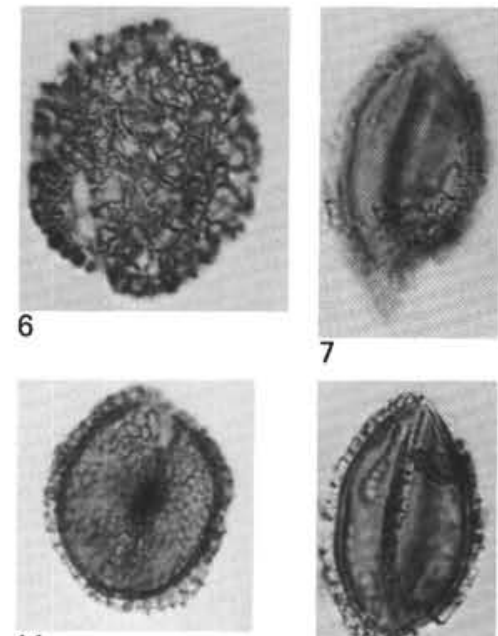

11
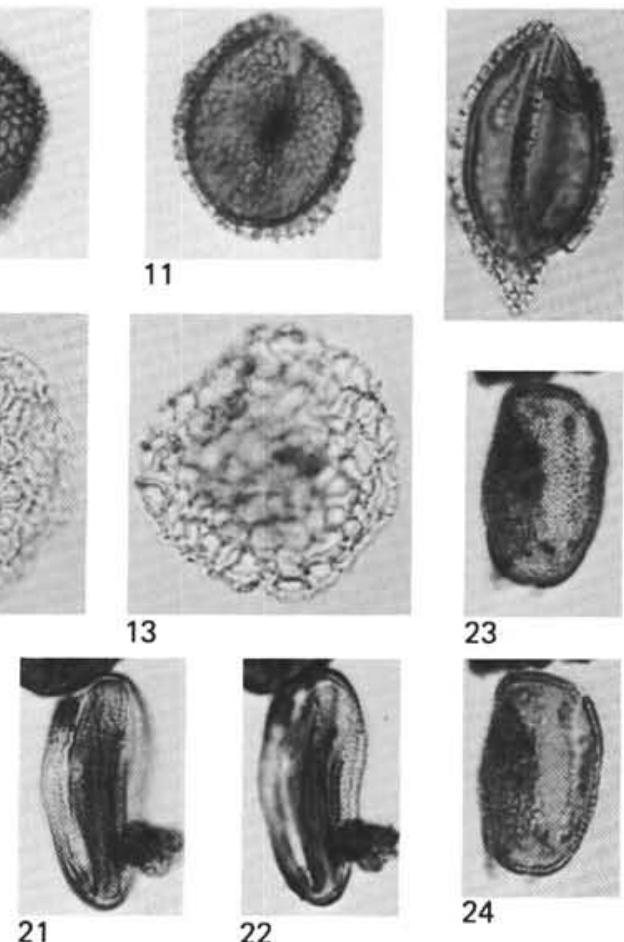

23

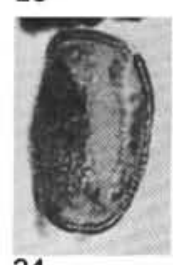

24
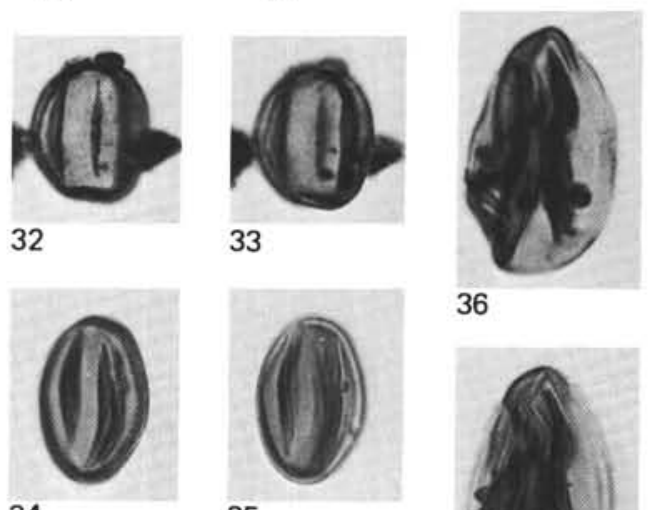

36

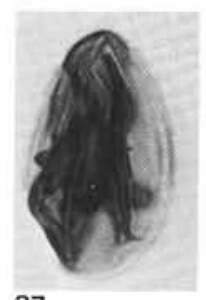

37
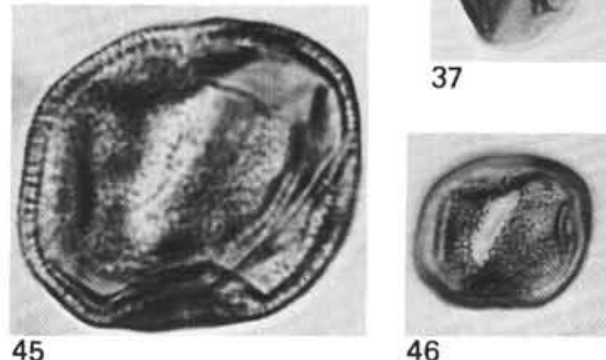

46 
PLATE 7

(All figures $\times 740$ unless otherwise indicated)

Figure $1 \quad$ Canningia colliveri Cooks. \& Eisenack 1960

Sample 417D-17-1, 94-95 cm (No. 2)

Figure 2 Canningia rotunda Cooks. \& Eisenack 1961

Sample 418A-10-1, 95-97 cm (No. 6)

Figures 3, 5 Canningia circularis Cooks. \& Eisenack 1971

Sample 418B-31-2, 11-13 cm (No. 3)

Sample 417D-17-1, 94-95 cm (No. 1)

Figure 4 Cribroperidinium muderongensis (Cooks. \& Eisenack) Davey 1969

Sample 417D-21-1, 108-110 cm (No. 2)

Figures 6, 7, Cribroperidinium sp. 1

9, 10 Sample 418A-10-1, 96-97 cm (No. 4)

Sample 418A-31-2, 11-13 cm (No. 3)

Figure 8 Diacanthum hollisteri Habib 1972

Sample 418B-29-2, 91-92 cm (No. 10)

Figure 11 Dictyopyxidia reticulata (Valensi) Lentin \& Williams 1973

Sample 418B-34-1, 30-31 cm (No. 2)

Figures 12, 13 cf. Pyxidiella sp.

Sample 417D-19-2, 6-8 cm (No. 8)

Figures 14-17 Ginginodinium spinulosum Cooks. \& Eisenack 1960 Sample 418B-31-2, 11-13 cm (Nos. 1 and 2)

Figure 18 Druggidium deflandrei (Millioud) Habib 1973 Sample 418B-34-1, 30-31 cm (No. 3)

Figure 19 Neiourogonyaulax psoros Davey \& Verdier 1974 Sample 417D-21-1, 108-110 cm (No. 1)

Figures 20, 21 Leptodinium cf. aculeatum Wall 1967

Sample 417D-17-1, 94-95 (No. 1)

Figures 22, 23 Fromea amphora Cooks. \& Eisenack 1958

Sample 417D-21-1, 108-110 cm (No. 2) 
PLATE 7
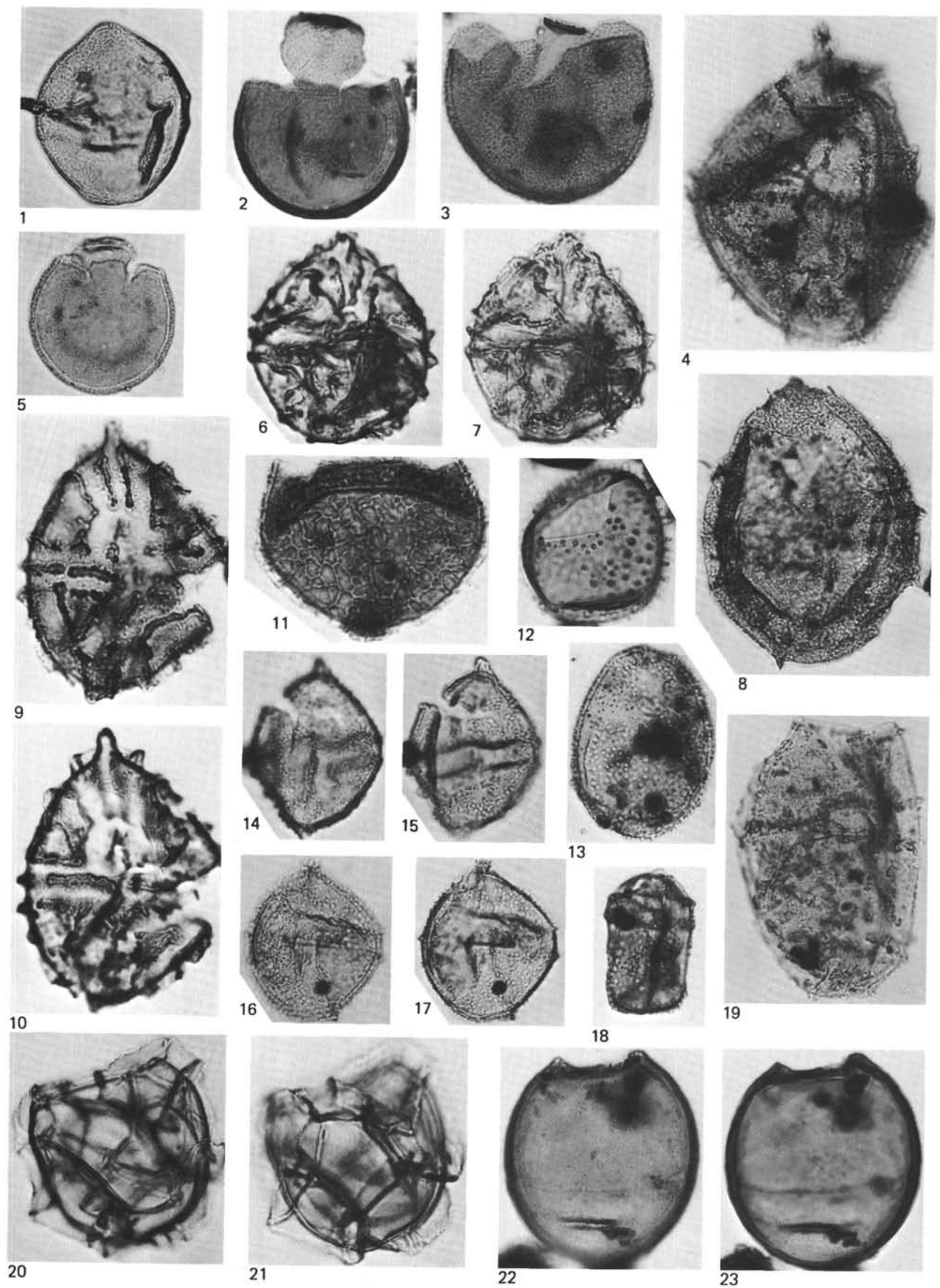

19

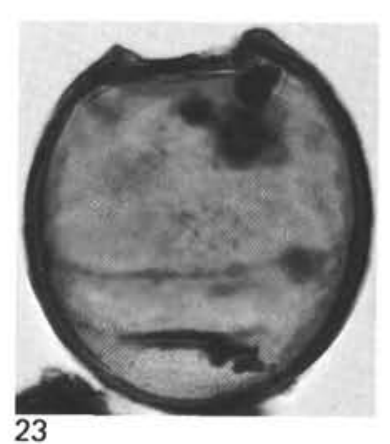


PLATE 8

(All figures $\times 750$ unless otherwise indicated)

Figures 1, 2 cf. Pyxidiella $\mathrm{sp}$.

Sample 418B-34-1, 30-31 cm (No. 3)

Figure 3 Leptodinium cf. margaritiferum (Cooks. \& Eisenack) Sarjeant 1969

Sample 418A-10-1, 95-97 cm (No. 6)

Figure $4 \quad$ Palaeoperidinium sp.

Sample 418B-34-1, 30-31 cm (No. 3)

Figures 5, 6 Gonyaulacysta ordovaca Duxbury 1977

Sample 417D-17-1, 94-95 cm (No. 3)

Figures 7,8 "'Scriniodinium attadalense"' (Cooks. Eisenack) Eisenack 1967

Sample 418B-3-12, 11-13 cm (No. 1)

Figures 9, 10 Chlamydophorella discreta Clarke \& Verdier 1967

Sample 418A, 10, CC (No. 2)

Figures 11, 12 Leptodinium alectrolophum Sarjeant 1966

Sample 417D-17-1, 94-95 cm (No. 2)

Figures 13, 14 Cleistosphaeridium huguonioti (Valensi) Davey 1969 Sample 418B-28-2, 53-55 cm (No. 8)

Figure 15 Cannosphaeropsis peridicta Eisenack \& Cooks. 1960 Sample 418B-29-2, 91-92 cm (No. 9)

Figure $16 \quad$ Cyclonephelium distictum subsp. brevispinatum (Millioud) Lentin \& Williams 1973

Sample 417D-17-1, 94-95 cm (No. 1)

Figure 17 Cometodinium sp.

Sample 417D-17-1, 94-95 cm (No. 2)

Figure $18 \quad$ Chlamydophorella discreta Clarke \& Verdier 1967

Sample 418A, 10, CC (No. 2)

Figures 19, 20 Lithosphaeridium conispinum Davey \& Verdier 1973 Sample 417D-17-1, 94-95 cm (No. 3)

Figure $21 \quad$ Actinotheca aphroditae Cooks. \& Eisenack 1960 Sample 418B-28-2, 53-55 cm (No. 8)

Figure 22 Hystrichosphaeridium arrundum Eisenack \& Cooks. 1960

Sample 418B-29-2, 91-92 cm (No. 9)

Figure 23 Gardodinium deflandrei Clarke \& Verdier 1967 417D, 17 cc (No. 5)

Figures 24, 25 Prolixosphaeridium granulosum (Defl. 1937) Davey et al. 1966

Sample 417D-21-1, 108-110 cm (No. 2)

Figure 26 Lithosphaeridium siphoniphorum (Cooks. \& Eisenack) Davey \& Williams, 1966

Sample 418B-31-2, 11-13 cm (No. 1) 
PLATE 8
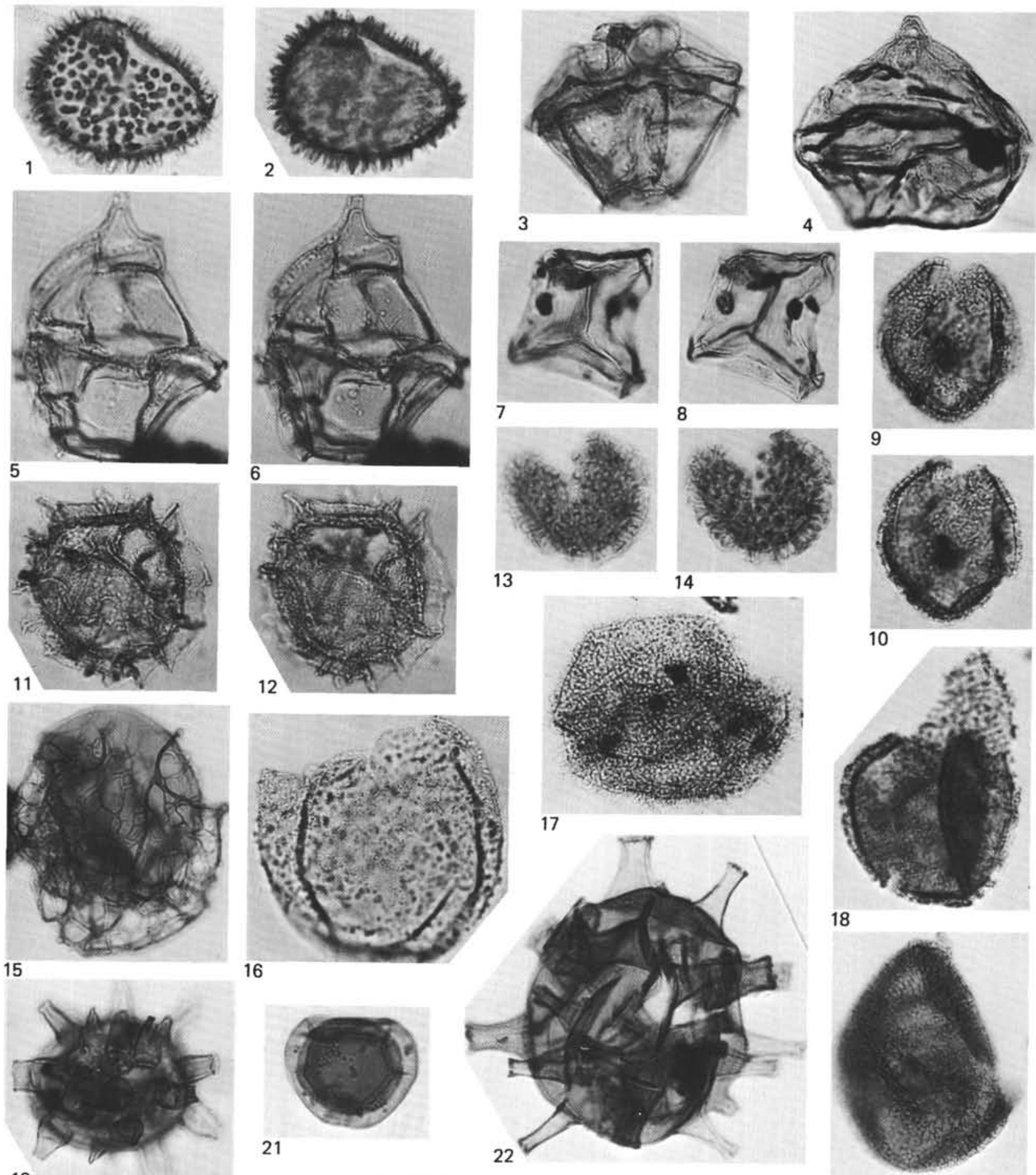

21
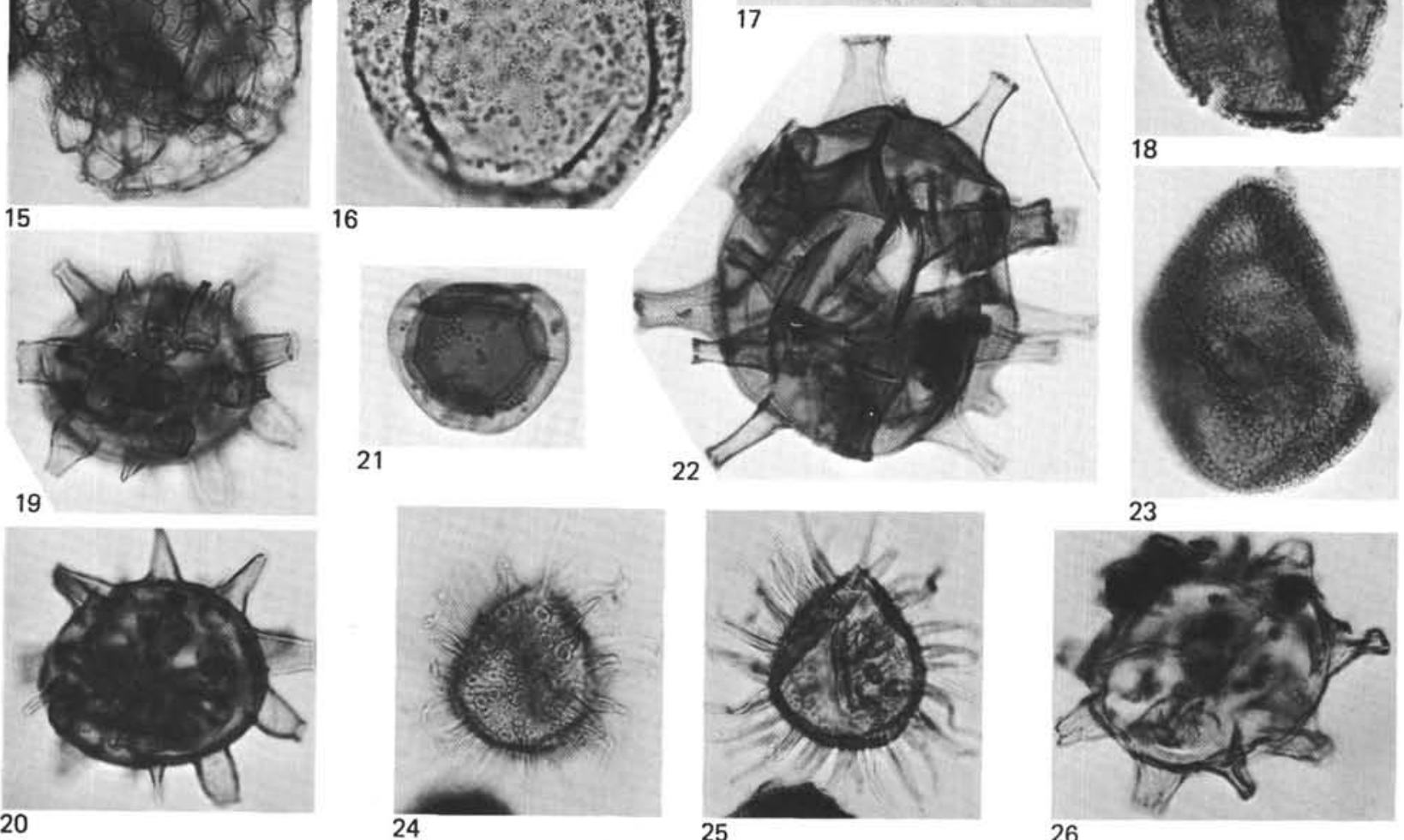
PLATE 9

(All figures $\times 750$ unless otherwise indicated)

Figures 1,2 Odontochitina operculata (Wetz.) Defl. \& Cooks. 1955

Sample 417D-21-1, 108-110 cm (No. 1)

Figure $3 \quad$ Palaeohystrichophora infusorioides Defl. 1935

Sample 418B-29-2, 91-92 cm (No. 9)

Figure 4 Xenikoon australis Cooks. \& Eisenack 1960

Sample 418B-31-2, 11-13 cm (No. 3)

Figure 5 Prolixosphaeridium deirense Davey et al. 1966

Sample 417D-21-1, 108-110 cm (No. 3)

Figure $6 \quad$ Systematophora fasciculigera Klement 1960

Sample 417D, 17, CC (No. 4)

Figure 7 Subtilisphaera perlucida (Alberti) Jain \& Millepied 1973

Sample 417D-18-1, 3-4 cm (No. 9)

Figure $8 \quad$ Xenikoon australis Cooks. \& Eisenack 1960

Sample 418B-31-2, 11-13 cm (No. 1)

Figures 9, $10 \quad$ Tytthodiscus sp. 1

Sample 417D-17-1, 94-95 cm (No. 3)

Figures 11, 12 ? Tytthodiscus sp. 3

Sample 417D-21-1, 108-110 cm (No. 2)

Figures 13, 14 Monogemmites cf. pseudosetarius (Weyl. \& Pf.) W. Kr. 1970

Sample 417D, 17, CC (No. 9)

Figure 15 Prolixosphaeridium granulosum (Defl. 1937) Davey et al. 1966

Sample 417D-19-2, 6-8 cm (No. 8)

Figures 16-19 Pleurozonaria sp. 1

Sample 418B-31-2, 11-13 cm (No. 2)

Figure $20 \quad$ Pterospermopsis helios Sarjeant 1974

Sample 417D-19-2, 11-14 cm (No. 7)

Figure $21 \quad$ Tytthodiscus sp. 2

Sample 417D-18-1, 3-4 cm (No. 9)

Figure $22 \quad$ Spermatites sp.

Sample 417D-19-2, 11-14 cm (No. 9)

Figure $23 \quad$ Micrhystridium fragile Defl. 1947

Sample 418B-31-2, 11-13 cm (No. 2)

Figures 24, 25 Monogemmites cf. pseudosetarius (Weyl. \& Pf.) W. Kr. 1970

Sample 417D, 17, CC (No. 9)

Figure 26 Microforaminifers (biserial)

Sample 418A-10-1, 95-97 cm (No. 4) 
PLATE 9
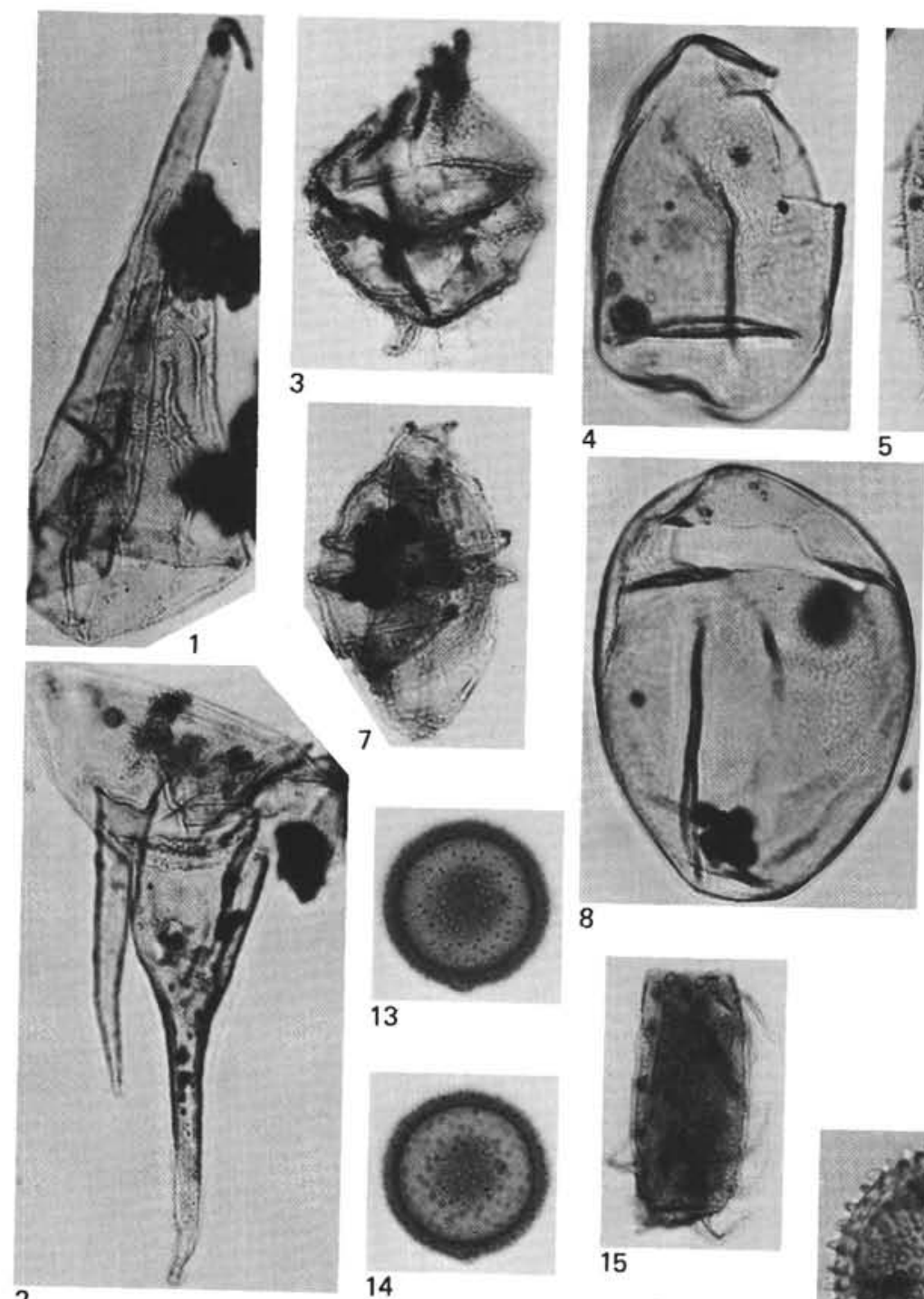

8

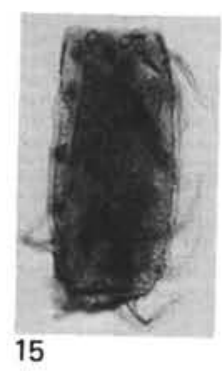

14
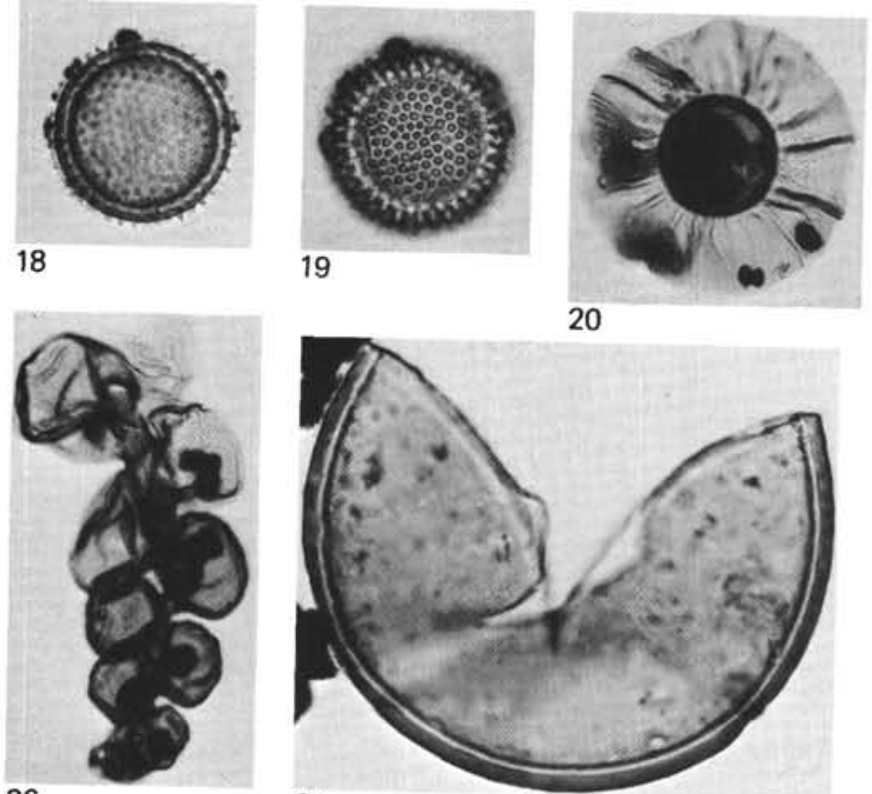

26

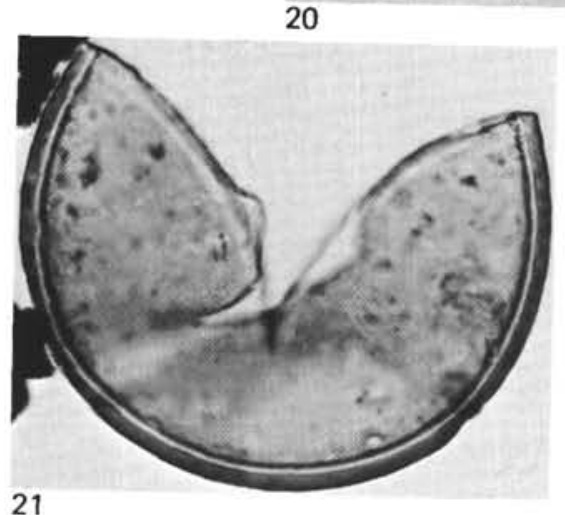

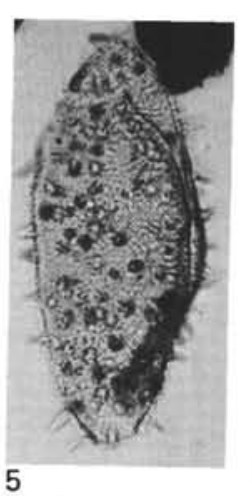
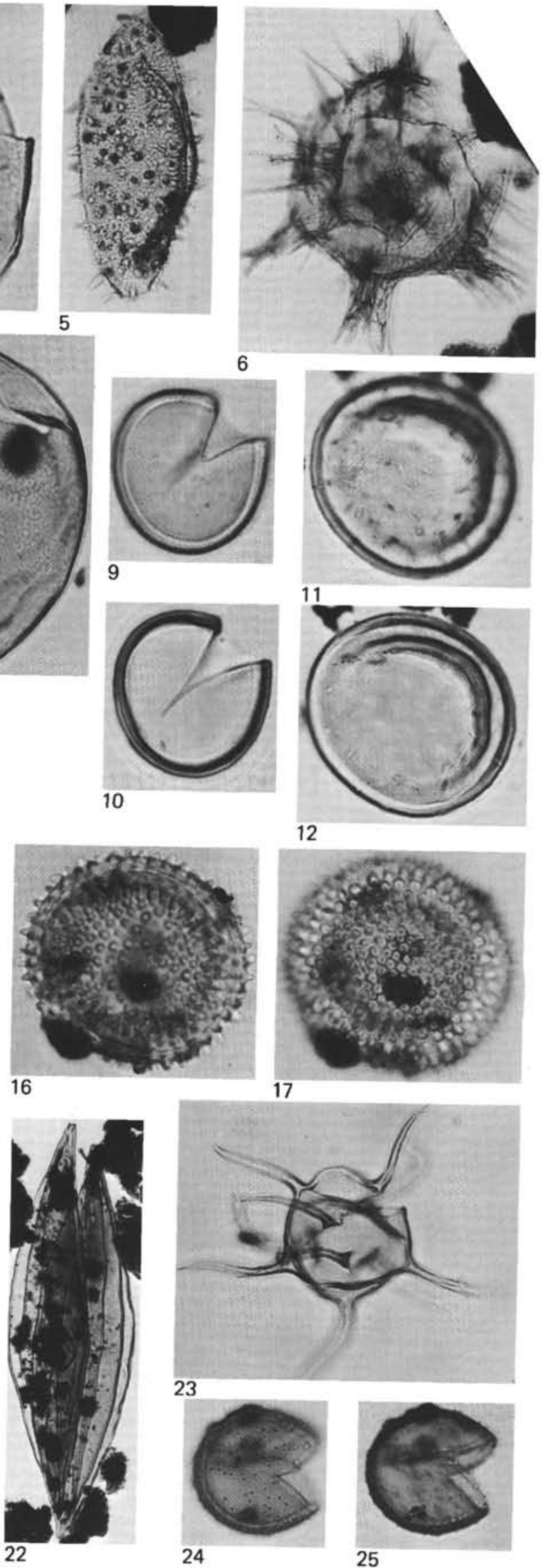